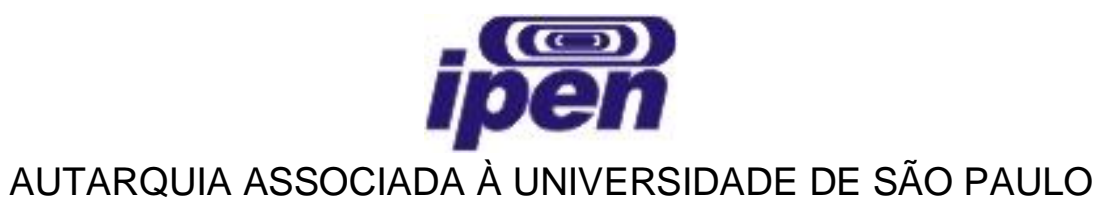

\title{
ASPECTOS ESTRUTURAIS DE PROTEÍNAS DO VENENO CROTÁLICO MODIFICADAS POR RADIAÇÃO IONIZANTE
}

KARINA CORLETO DE OLIVEIRA

Dissertação apresentada como parte dos requisitos para obtenção do Grau de Mestre em Ciências na Área de Tecnologia Nuclear - Aplicações

Orientadora:

Dra. Nanci do Nascimento

SÃO PAULO

2010 
Dedico este trabalho à minha família: meus pais, Antonio e Sonia, e meu irmão Danilo. Segue a certeza de que sem vocês eu nada seria. 


\section{AGRADECIMENTOS}

Primeiramente a Deus, porque nada aconteceria sem esta luz.

À Dra. Nanci do Nascimento, minha orientadora, pelo apoio constante, pela amizade e confiança, pelos momentos de descontração e sobretudo por ser um exemplo de simplicidade a ser seguido.

Ao amigo Patrick Jack Spencer pela ajuda constante no laboratório, por todas as sugestões e conversas. A sua sabedoria certamente tornou este trabalho melhor.

Ao Dr. Daniel Carvalho Pimenta pelas dicas e sugestões dadas no seminário de área e por se mostrar sempre disposto a ajudar.

Ao amigo Dr. Murilo Casare da Silva pelas diversas vezes que me auxiliou, mesmo de longe, compartilhando idéias e sugestões para o desenvolvimento deste trabalho.

À Dra. Maria Teresa C. Ribela pelas dicas no seminário de área.

Ao amigo José Alberto Alves da Silva, Tinho, pelo seu característico senso de humor e por ser um excelente amigo.

À amiga Janaína Baptista Alves por todos os ensinamentos e carinho nesses dois anos de convivência.

À amiga Natália Malavasi por toda ajuda, pelas conversas e desabafos, e por sempre tornar o ambiente a sua volta muito mais divertido.

À amiga Larissa Pereira Miranda pela ajuda, conversas, risadas e por ser esta pessoa tão especial.

À amiga Danielle Borim por ser uma pessoa maravilhosa e, mesmo em tão pouco tempo de convívio, ter se tornado uma pessoa muito querida.

Ao amigo Felipe Guimarães Albero por toda ajuda incondicional, grande amizade e especialmente pelos experimentos de FTIR. 
Às amigas Keli, Juliana e Rosa, por todas as risadas e momentos descontraídos.

Aos amigos Johnny e José Maria por estarem presentes nos momentos de desespero e pelos momentos divertidos.

Às amigas Taís, Renata e Beatriz por tantas conversas, momentos engraçados e pelo carinho.

Às meninas Geyza, Eliza, Miriam, Fernanda e Claudinha pelos diversos momentos compartilhados.

Às amigas Dani e Stefany pelos momentos de descontração e pelas divertidas histórias no Rio de Janeiro.

Aos amigos Rodrigo, Vicente e Tamara por vários momentos de descontração na nossa salinha de estudo, bagunça e risadas.

À amiga Erika Yumi por compartilhar comigo diversos momentos importantes.

Aos amigos Marcos Antonio Júnior e Eduardo de Moura, por todo o auxílio prestado desde o início deste trabalho.

Ao amigo Jean por várias dicas, conversas e inúmeros momentos engraçados.

Aos amigos do Centro de Lasers e Aplicações, Carolina, Juca, Moisés, Thiago, Marcelo e Marcus pelos inúmeros momentos de risadas compartilhados principalmente nos congressos de Física.

Aos antigos amigos por ainda fazerem parte desta caminhada.

Aos demais pesquisadores e integrantes do Centro de Biotecnologia, por toda a colaboração que, com certeza, foi de grande importância no decorrer deste trabalho.

Às Dras. Duclerc F. Parra, Nilce Ortiz (Centro de Química e Meio Ambiente) e Denise M. Zezell (Centro de Lasers e Aplicações) por 
possibilitarem o uso de equipamentos de Calorimetria Diferencial, Fluorescência e Infravermelho.

Aos técnicos Leonardo do Instituto Butantan, e Eleosmar do Centro de Química e Meio Ambiente - IPEN, por toda ajuda nos experimentos de Dicroísmo Circular e Calorimetria Diferencial.

Às amigas Arlete, Rute e Neidinha, por todos os momentos de descontração compartilhados e por sempre terem ajudado em tudo que lhes cabia.

A todos os funcionários do centro pelo cuidado e limpeza dos materiais do laboratório.

Aos integrantes da Comissão de Pós-graduação pela ajuda constante nos assuntos burocráticos e pelos momentos divertidos.

À CNEN pelo apoio financeiro.

A todos que direta ou indiretamente colaboraram no desenvolvimento deste projeto, o meu sincero muito obrigado.

E, a vocês, família querida, por todos os ensinamentos que jamais serão resumidos a palavras...

"Fica a certeza de que no final do caminho, o que realmente vale à pena são as pessoas" 
"Todo o bem que eu puder fazer, toda a ternura que eu puder demonstrar a qualquer ser humano, que eu os faça agora, que não os adie ou esqueça, pois não passarei duas vezes pelo mesmo caminho"

(James Greene)

"Aquilo que pensamos saber, com frequência nos impede de aprender" (Claude Bernard) 


\title{
ASPECTOS ESTRUTURAIS DE PROTEÍNAS DO VENENO CROTÁLICO MODIFICADAS POR RADIAÇÃO IONIZANTE
}

\author{
Karina Corleto de Oliveira
}

\section{RESUMO}

Os acidentes ofídicos representam um sério problema de Saúde Pública, principalmente em países subtropicais. No Brasil, segundo o Ministério da Saúde, foram notificados cerca de 26000 acidentes em 2008. O gênero Crotalus (cascavéis) é responsável por aproximadamente $7 \%$ do total, porém apresenta um alto índice de letalidade, sendo que $72 \%$ dos casos de acidentados sem o tratamento adequado com soro específico (soro anticrotálico) chegam ao óbito. A produção de soro no Brasil, único tratamento eficaz nos casos de acidentes ofídicos, utiliza equinos que, apesar do grande porte, apresentam diminuição da longevidade quando comparado com os cavalos não imunizados. A radiação ionizante tem se mostrado como excelente ferramenta na diminuição da toxicidade de venenos e toxinas isoladas e tem resultado na obtenção de melhores imunógenos para a produção de soro, além de contribuir para o bem estar dos animais soro-produtores. Visto que a ação da radiação gama em toxinas ainda não está totalmente esclarecida do ponto de vista estrutural, foi proposto neste trabalho, a caracterização de duas proteínas da espécie Crotalus durissus terrificus: a crotoxina e a crotamina. Após o isolamento das toxinas de interesse por técnicas cromatográficas, estas foram submetidas às análises estruturais com a aplicação das seguintes metodologias: Fluorescência, Dicroísmo Circular, Calorimetria Diferencial e Espectroscopia Infravermelho. Estas análises mostraram que tanto a crotamina como a crotoxina, quando submetidas à radiação gama, apresentaram alterações na conformação estrutural em comparação com as amostras no estado nativo. Tais alterações possivelmente ocorrem na estrutura terciária e secundária das proteínas e podem explicar as modificações quanto à atividade biológica destas toxinas. 


\title{
STRUCTURAL ASPECTS OF CROTALIC VENOM PROTEINS MODIFIED BY IONIZING RADIATION
}

\section{Karina Corleto de Oliveira}

\begin{abstract}
Snake bites are a serious public health problem, especially in subtropical countries. In Brazil, the Ministry of Health notified around 26000 accidents in 2008. The genus Crotalus (rattlesnakes) accounts for approximately $7 \%$ of the total, with a high mortality rate of $72 \%$ when untreated with the specific serum, the only effective treatment in case of snake bites. In Brazil, the serum is produced in horses which, despite the large size, have a reduced lifespan due to the high toxicity of the antigen. lonizing radiation has proven to be an excellent tool for reducing the toxicity of venoms and isolated toxins, resulting in better immunogens for serum production, and contributing to the welfare of serumproducing animals. Since the action of gamma radiation on venoms and toxins has not been yet fully clarified from the structural point of view, we proposed in this paper, to characterize two toxins of the species Crotalus durissus terrificus: crotoxin and crotamine. After isolation of the toxins of interest by chromatographic techniques, they were subjected to structural analysis with the application of the following methods: Fluorescence, Circular Dichroism, Differential Calorimetry and Infrared Spectroscopy. These tests showed that both crotamine as crotoxin when subjected to gamma radiation, showed changes in their structural conformation compared with the samples in the native state. Such changes probably occur in the secondary and tertiary structure and may explain the changes on the biological activity of these toxins.
\end{abstract}




\section{SUMÁRIO}

Páginas

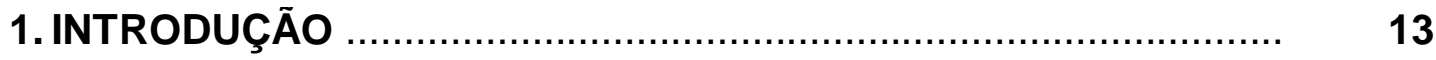

1.1 As serpentes e o seu veneno ………………..................... 14

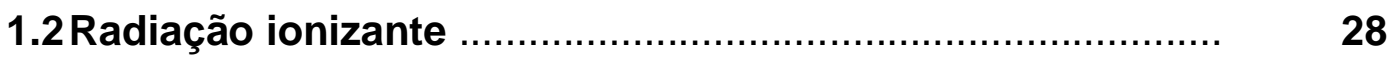

2. OBJETIVOS …….........................................................

3. MATERIAL E MÉTODOS ……................................................

3.1 Isolamento das toxinas ……….......................................

3.1.1 Cromatografia de exclusão molecular ………………....... 35

3.1.2 Cromatografia de troca iônica ......................................... $\quad 36$

3.1.3 Cromatografia de exclusão molecular de alta eficiência (HPSEC)

3.1.4 Cromatografia de fase reversa (RP-HPLC) ..................... $\quad 37$

3.1.5 Cromatografia de exclusão molecular (desalting).............. 37

3.2 Dosagem protéica ......................................................... $\quad 38$

3.3 Irradiação das proteínas …………………………............ $\quad 38$

3.4 Análise de Fluorescência ……………………................ $\quad 39$

3.4.1 Princípio de análise por Fluorescência ............................. 39

3.4.2 Procedimento para análise de Fluorescência .................... 40

3.5 Dicroísmo Circular ............................................................ 40

3.5.1 Princípio de análise por Dicroísmo Circular ..................... $\quad 40$

3.5.2 Procedimento para análise de Dicroísmo Circular ............ 4

3.6 Calorimetria Diferencial ............................................... 42

3.6.1 Princípio de análise por Calorimetria Diferencial .............. 42

3.6.2 Procedimento para análise de Calorimetria Diferencial .... 44

3.7 Espectroscopia de Infravermelho ....................................

3.7.1 Princípio de análise por Infravermelho .............................. 44 
3.7.2 Procedimento para análise de Infravermelho

4. RESULTADOS ……........................................................ 48

4.1 Isolamento da crotoxina e da crotamina ............................ 48

4.2 Fluorescência ..................................................................

4.3 Dicroísmo Circular ........................................................... $\quad 59$

4.4 Espectroscopia de Infravermelho ………......................... 61

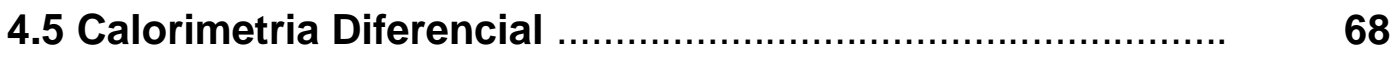

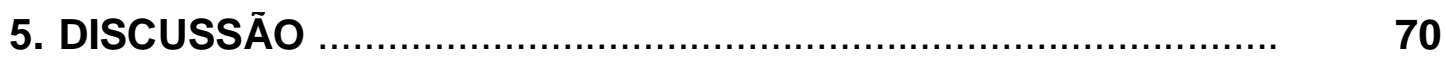

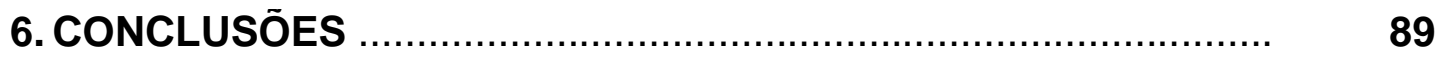

REFERÊNCIAS BIBLIOGRÁFICAS ............................................ 90 


\section{LISTA DE FIGURAS}

Páginas

Figura 1 Regiões anatômicas da glândula de veneno das serpentes 14 viperídeas: glândula principal, ducto primário, glândula acessória e ducto secundário.

Figura 2 Estimativa regional de envenenamentos por picadas de serpentes em regiões/ano, definidas pelo GBD.

Figura 3 Representação esquemática da microscopia eletrônica da estrutura da junção neuromuscular, apresentando a separação dos elementos pré e pós-sinápticos.

Figura 4 Sequência da crotapotina deduzida a partir da sequência da 20 proteína.

Figura 5 Sequência da $\mathrm{PLA}_{2}$ deduzida diretamente da sequência da proteína.

Figura 6 Fotomicrografias de cristais da $\mathrm{PLA}_{2}$ (a) e da crotapotina (b). 21

Figura 7 Estrutura tridimensional do complexo tetramérico formado por 222 dímeros de isoformas (CB1 e CB2) da subunidade básica $\left(\mathrm{PLA}_{2}\right)$ isoladamente.

Figura 8 Sequência de aminoácidos da crotamina com indicação das pontes dissulfeto.

Figura 9 Efeito da crotamina nos membros posteriores quando injetada de forma intraperitoneal.

$\begin{array}{lll}\text { Figura } 10 \text { Estrutura tridimensional da crotamina resolvida por RMN. } & 27\end{array}$

Figura 11 Processo de ionização atômica. 28

Figura 12 O espectro eletromagnético. 45

Figura 13 Sistema ilustrativo do princípio da técnica de ATR. O feixe 46 infravermelho sofre sucessivas reflexões no interior do cristal.

Figura 14 Cromatograma do veneno total da C.d.terrificus em coluna de 48 exclusão molecular Superdex G-75.

Figura 15 Recromatografia da crotoxina em coluna de troca aniônica (Mono Q).

Figura 16 Recromatografia da crotamina em coluna de troca catiônica 50 (Resource S).

Figura 17 Gel filtração analítica da fração correspondente à crotoxina após a 51 primeira etapa de purificação.

Figura 18 Gel filtração analítica da fração correspondente à crotamina após a 52 primeira etapa de fracionamento. 
Figura 19 Gel filtração analítica da fração correspondente à crotoxina após a 53 segunda etapa de isolamento.

Figura 20 Gel filtração analítica da fração correspondente à crotamina após a 54 segunda etapa de isolamento.

Figura 21 Perfil cromatográfico obtido na desalting (Sephadex G-10) da 55 crotamina após troca iônica.

Figura 22 Cromatografia de fase reversa (coluna C8) da crotamina. 56

Figura 23 Análise de fluorescência da crotoxina nativa e irradiada. 57

Figura 24 Análise de fluorescência da crotamina nativa e irradiada. 58

Figura 25 CD da crotoxina nos estados nativo e irradiado. 59

Figura 26 Análise de CD da crotamina nativa e irradiada. 60

Figura 27 Espectro de ATR-FTIR da crotoxina no estado nativo (curva preta) e 61 irradiado (curva vermelha).

Figura 28 Espectro de ATR-FTIR da crotamina no estado nativo (curva preta) e irradiado (curva vermelha).

Figura 29 Espectro da região da banda da amida I, obtido por ATR-FTIR, da crotoxina no estado nativo (curva preta) e irradiado (curva vermelha).

Figura 30 Espectro da região da banda da amida I, obtido por ATR-FTIR, da crotamina no estado nativo (curva preta) e irradiado (curva vermelha).

Figura 31 Espectros de ATR-FTIR (segunda derivada) da crotoxina nativa (curva preta) e irradiada (curva vermelha).

Figura 32 Espectros de ATR-FTIR (segunda derivada) da crotamina nativa (curva preta) e irradiada (curva vermelha).

Figura 33 Histograma das frações da estrutura secundária da crotoxina, comparando as quantidades estruturais encontradas na amostra nativa (barras azuis) e irradiada (barras roxas).

Figura 34 Histograma das frações da estrutura secundária da crotamina, comparando as quantidades estruturais encontradas na amostra nativa (barras azuis) e irradiada (barras roxas).

Figura 35 Análise de calorimetria diferencial da crotoxina nativa $(\mathbf{A})$ e irradiada (B).

Figura 36 Análise de calorimetria diferencial da crotamina nativa (A) e 69 irradiada (B). 


\section{LISTA DE TABELAS}

Páginas

Tabela 1 Composição de aminoácidos da crotamina. 24

Tabela 2 Dados referentes à cromatografia do veneno total da 49 C.d.terrificus.

Tabela 3 Dados referentes à recromatografia (troca aniônica) da 50 crotoxina.

Tabela 4 Dados referentes à recromatografia (troca catiônica) da 51 crotamina.

Tabela 5 Dados referentes à gel filtração analítica da crotoxina após a 52 primeira etapa de fracionamento.

Tabela 6 Dados referentes à gel filtração analítica da crotamina após 53 primeira etapa de fracionamento.

Tabela 7 Dados referentes à gel filtração analítica da crotoxina após 54 segunda etapa de fracionamento.

Tabela 8 Dados referentes à gel filtração analítica da crotamina após segunda etapa cromatográfica.

Tabela 9 Valores comparativos da estrutura secundária da crotoxina e $\quad 80$ suas subunidades.

Tabela 10 Estrutura secundária da crotoxina e crotamina a partir das técnicas de CD e ATR-FTIR. 


\section{INTRODUÇÃO}

Desde a Antiguidade, o homem tem buscado utilizar o veneno de serpente em seu próprio benefício. Aristóteles, Hipócrates e Plínio escreveram sobre a sua multiplicidade de efeitos e Galeano regularmente usava venenos como agentes terapêuticos. A serpente inteira, incluindo o seu veneno, era usada em muitas preparações. Pulverizado ou macerado, supunha-se que o animal transmitisse as propriedades do seu veneno ao líquido no qual era misturado.

Os primeiros trabalhos tentando identificar os componentes de venenos de serpentes datam do século XIX. Em 1843, Lucien Bonaparte purificou uma substância do veneno de víbora, a qual denominou viperina, por meio de uma série de precipitações com álcool e éter. Assim como Mitchell, em 1860, isolou a crotalina do veneno de cascavel, utilizando o método de filtração por uma membrana semipermeável (Oguiura, 1998). Desta forma, paralelamente à evolução da ciência, muito se tem acumulado de conhecimento sobre as toxinas em geral.

O estudo farmacológico e bioquímico do veneno de animais e de suas toxinas é da mais alta importância sob múltiplos aspectos. Somente por meio dele é possível adquirir conhecimento adequado da fisiopatologia dos envenenamentos e instituir medidas racionais e eficientes em seu tratamento. Assim, diversos estudos de venenos animais têm revelado substâncias promissoras em terapêutica. Rocha \& Silva, em 1948, descobriram os peptídeos hipotensores de venenos botrópicos que serviram como modelo para o desenho de drogas hipotensivas muito usadas atualmente, como o Captopril ${ }^{\circledR}$. Várias outras substâncias, derivadas de toxinas de serpentes, têm sido estudadas a fim de serem utilizadas como anticoagulantes, como por exemplo, a Reptilase ${ }^{\circledR}$, enzima com estrutura homóloga à trombina de Bothrops atrox, que permite a detecção e quantificação de fibrinogênio, mesmo em pacientes tratados com um anticoagulante, como a heparina; o $\operatorname{Protac}^{\circledR}$, um ativador de proteína $\mathrm{C}$ em pessoas com um risco alto de trombose vascular, dentre outros (Bon, 1994).

No caso específico dos venenos crotálicos, que são formados em quase sua totalidade por proteínas, a determinação experimental da estrutura conformacional das mesmas pode promover um sólido entendimento da sua 
função biológica (Peltron \& McLean, 2000), o que formaria a base de conhecimento para estudos bioquímicos posteriores.

\subsection{As serpentes e o seu veneno}

As serpentes estão distribuídas pelo mundo inteiro. São conhecidas cerca de 3300 espécies, classificadas em 15 famílias (Pough e cols., 1998). As serpentes que produzem secreções tóxicas ocorrem em apenas 4 dessas famílias: Atractaspidae, Colubridae, Elapidae e Viperidae (Mènez, 1994).

As serpentes da família Viperidae possuem o mecanismo de injeção de veneno mais desenvolvido e são divididas em 2 outras subfamílias: Viperinae, encontrada na Eurásia e África, e Crotalinae, que inclui as cascavéis, localizada nas Américas e no sudeste Asiático.

A glândula de veneno das serpentes viperídeas (Figura 1) são glândulas exócrinas com quatro regiões bem definidas: a glândula principal, onde é produzido o veneno; o ducto primário; a glândula acessória, local onde o veneno é armazenado até que seja expelido; e o ducto secundário que desemboca na presa (Rotenberg e cols., 1971; de Lucca e cols., 1974; Brown e cols., 1975; Paine e cols., 1992).

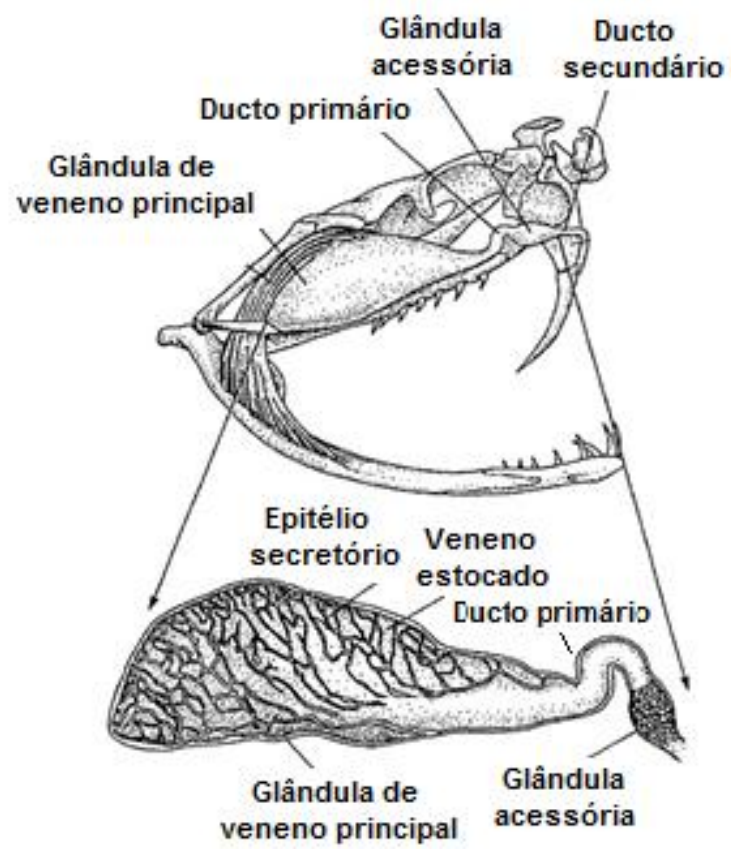

Figura 1: Regiões anatômicas da glândula de veneno das serpentes viperídeas: glândula principal, ducto primário, glândula acessória e ducto secundário (Kardong, 2002, modificado). 
O veneno é parte desse aparato constituído pelas glândulas de veneno e pelo sistema de injeção. De uma forma geral, os venenos são maus imunógenos e apresentam alta toxicidade (Tocker e cols., 1990), sendo que a sua função primária é auxiliar no processo de captura da presa. Sabe-se também que o veneno possui uma função importante na digestão, seja para aumentar a sua velocidade como para ativar a degradação da presa no intestino (Thomas \& Pough, 1979).

Os venenos ofídicos são misturas complexas constituídas por proteínas (70 a 90\%), em sua maioria toxinas ou enzimas tóxicas. A fração não protéica dos venenos das serpentes consiste de cátions e ânions inorgânicos, substâncias de baixa massa molecular como aminoácidos, pequenos peptídeos, lipídeos, nucleotídeos e nucleosídeos, carboidratos e aminas (Devi, 1971; Stocker, 1990). Os elementos inorgânicos mais frequentes são $\mathrm{Ca}, \mathrm{Cu}, \mathrm{Fe}, \mathrm{K}, \mathrm{Mg}, \mathrm{Mn}, \mathrm{Na}, \mathrm{P}, \mathrm{Co}$, Zn. O papel biológico de cada um desses metais ainda não está claro, entretanto, sabe-se que alguns deles, como $\mathrm{Ca}, \mathrm{Mg}$ e $\mathrm{Mn}$, são de grande importância na estabilização de certas proteínas de veneno, enquanto outros, em particular Zn, $\mathrm{Fe}, \mathrm{Cu}$, e Co, podem agir como catalisadores em reações enzimáticas (Bjarnason \& Fox, 1988).

Os acidentes ofídicos representam um sério problema de Saúde Pública, principalmente em países subtropicais. Estima-se que, anualmente, ocorram pelo menos 421000 acidentes no mundo com aproximadamente 20000 óbitos (Kasturiratne e cols., 2008). A Figura 2 ilustra o número de acidentes por região por ano. As regiões indicadas foram definidas pelo Global Burden of Disease $^{1}$ - GBD. 


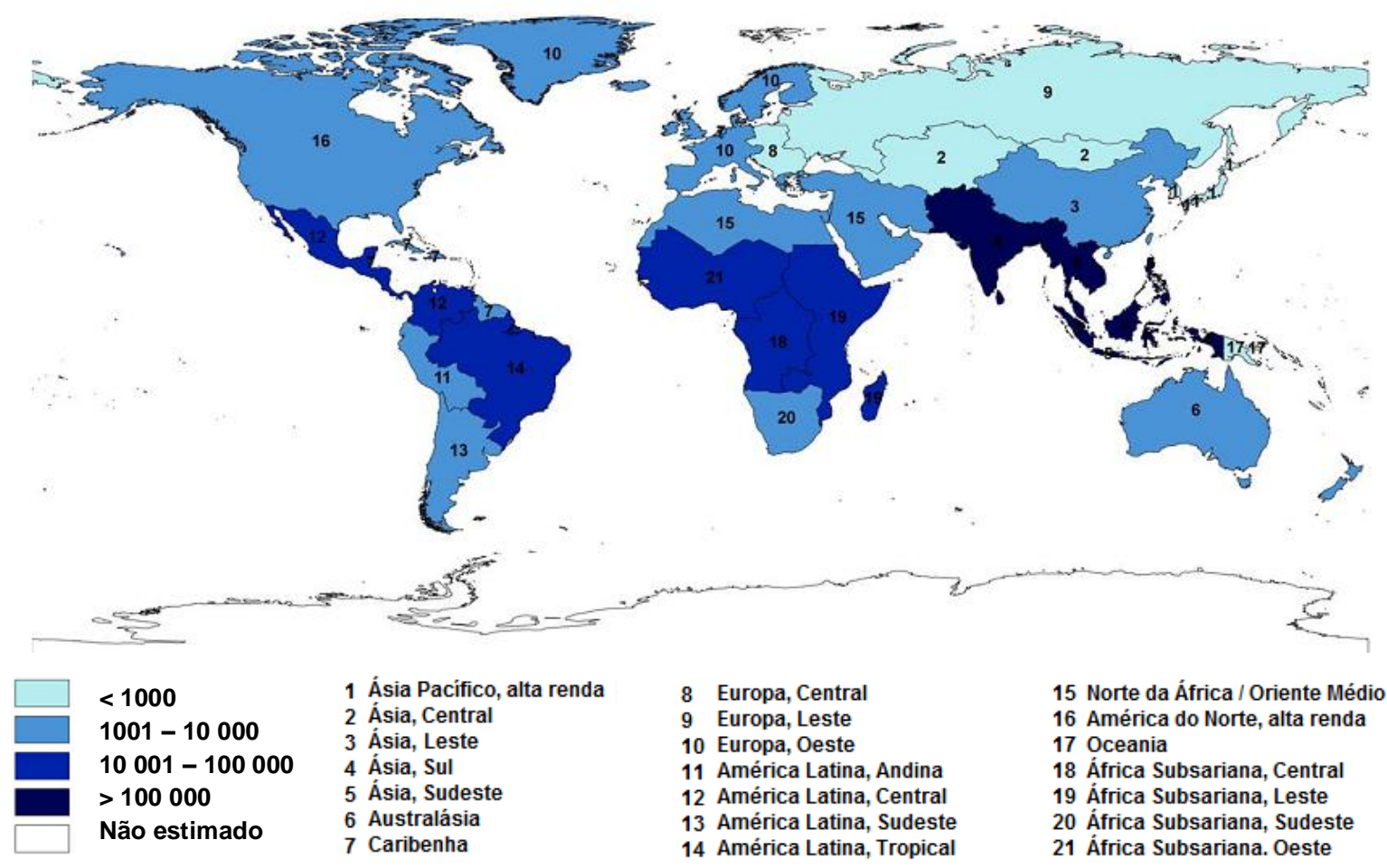

Figura 2: Estimativa regional de envenenamentos por picadas de serpentes em regiões/ano, definidas pelo GBD (Kasturiratne e cols., 2008, modificado).

No Brasil, segundo o Ministério da Saúde ${ }^{2}$, foram notificados cerca de 26000 acidentes em 2008, sendo que destes, aproximadamente 75\% ocorreram com serpentes pertencentes ao gênero Bothrops. As serpentes dos gêneros Crotalus, Lachesis e Micrurus contribuem com 7,4\%, 3,0\% e 1,0\% dos casos, respectivamente (Ribeiro \& Jorge 1990, 1997; Bochner \& Struchiner 2002, 2003; Araújo e cols., 2003; França \& Málaque, 2003). A maioria das notificações é procedente das regiões meridionais do país, ocorrem no período de setembro a março, e estão relacionadas ao trabalho humano no campo (Silva, 2005).

O gênero Crotalus, ao qual pertencem as serpentes popularmente conhecidas como cascavéis, apresenta um alto índice de letalidade, sendo que $72 \%$ dos casos de acidentados sem o tratamento adequado com soro específico (soro anticrotálico) chegam ao óbito e apenas $11 \%$ dos casos tratados corretamente atingem tal situação (Rosenfeld, 1991).

Das serpentes do gênero Crotalus, a espécie Crotalus durissus é a mais amplamente distribuída no Brasil. Segundo Hoge \& Romano-Hoge (1978, 1979), são encontradas no país 5 subespécies: 
- C.d.cascavella, em regiões secas do Nordeste brasileiro e extremo nordeste de Minas Gerais;

- C.d.collilineatus, no Mato Grosso, Goiás, Minas Gerais, São Paulo e sul do Brasil;

- C.d.marajoensis, nos campos da llha de Marajó;

- C.d.ruruima, na região do cerrado do estado de Roraima;

- C.d.terrificus, em Minas Gerais, São Paulo, Santa Catarina, Paraná, Rio Grande do Sul e Mato Grosso do Sul.

No caso específico do veneno da subespécie Crotalus durissus terrificus, há 5 componentes farmacologicamente ativos identificados até então: convulxina, delta toxina, giroxina, crotoxina e crotamina. Estas duas últimas serão melhor detalhadas uma vez que correspondem às toxinas de interesse neste estudo.

A convulxina é uma glicoproteína com massa molecular de $72 \mathrm{kDa}$ cuja toxicidade foi estuda em vários modelos animais, produzindo, quando inoculada por via intravenosa, efeitos como: convulsões tônico-clônicas, alterações circulatórias e respiratórias, além de ativar e agregar plaquetas na ausência de fibrinogênio (Vargaftig e cols., 1983).

A delta toxina, primeiramente estudada por Vital Brazil (1980) que mencionou uma ação hemoconcentrante por alteração na permeabilidade vascular. Campos (2006) isolou e caracterizou esta molécula mostrando que tal toxina (massa molecular estimada em $40 \mathrm{kDa}$ ) possui atividade agregadora de plaquetas e ativadora de fatores de coagulação.

A giroxina possui massa molecular de $34 \mathrm{kDa}$ e provoca uma síndrome convulsiva caracterizada por movimentos circulatórios do corpo ao longo de seu eixo longitudinal, particularmente em camundongos. A giroxina ainda apresenta atividade coagulante do fibrinogênio no plasma de mamíferos, exercendo assim uma atividade do tipo trombina (Alexandre e cols., 1988). 
A crotoxina é o principal componente tóxico do veneno da C.d.terrificus, representando cerca de $70 \%$ da sua massa total. Foi a primeira neurotoxina animal a ser purificada e cristalizada. As primeiras investigações também mostraram que a crotoxina possui atividade fosfolipásica (Slotta \& Fraenkel-Conrat, 1938; Hortnagl \& Hanin, 1992).

Esta proteína apresenta atividades tóxicas paralisantes, hemolíticas indiretas in vitro (Vital Brazil e cols., 1966a) e miolíticas (Azevedo-Marques e cols., 1987). A crotoxina pode causar morte por paralisia respiratória (Vital Brazil e cols., 1973), no entanto, a maior parte dos óbitos ocorre devido à insuficiência renal aguda (Vital Brazil, 1980).

Sabe-se que as neurotoxinas exercem sua ação fisiopatológica por inibirem a transmissão neuromuscular, bloqueando a liberação de acetilcolina na junção neuromuscular (Figura 3) (Vital Brazil \& Excell, 1971). Este efeito primário da crotoxina caracteriza a sua ação pré-sináptica e ocorre em três etapas sucessivas: inicialmente um efeito depressor, seguido por uma breve facilitação da liberação do transmissor e finalmente um bloqueio da liberação da acetilcolina do nervo motor terminal (Hawgood \& Smith, 1977; Chang \& Lee, 1977; Chang, 1985; Harvey e cols., 1990; Gallacci e cols., 2000). Em adição aos seus efeitos pré-sinápticos, a crotoxina também age de forma pós-sináptica bloqueando a resposta à acetilcolina através da estabilização do receptor colinérgico em um estado conformacional inativo (Vital Brazil, 1966b; Hanley, 1978; Bon e cols., 1979; Faure \& Bon, 1988). 


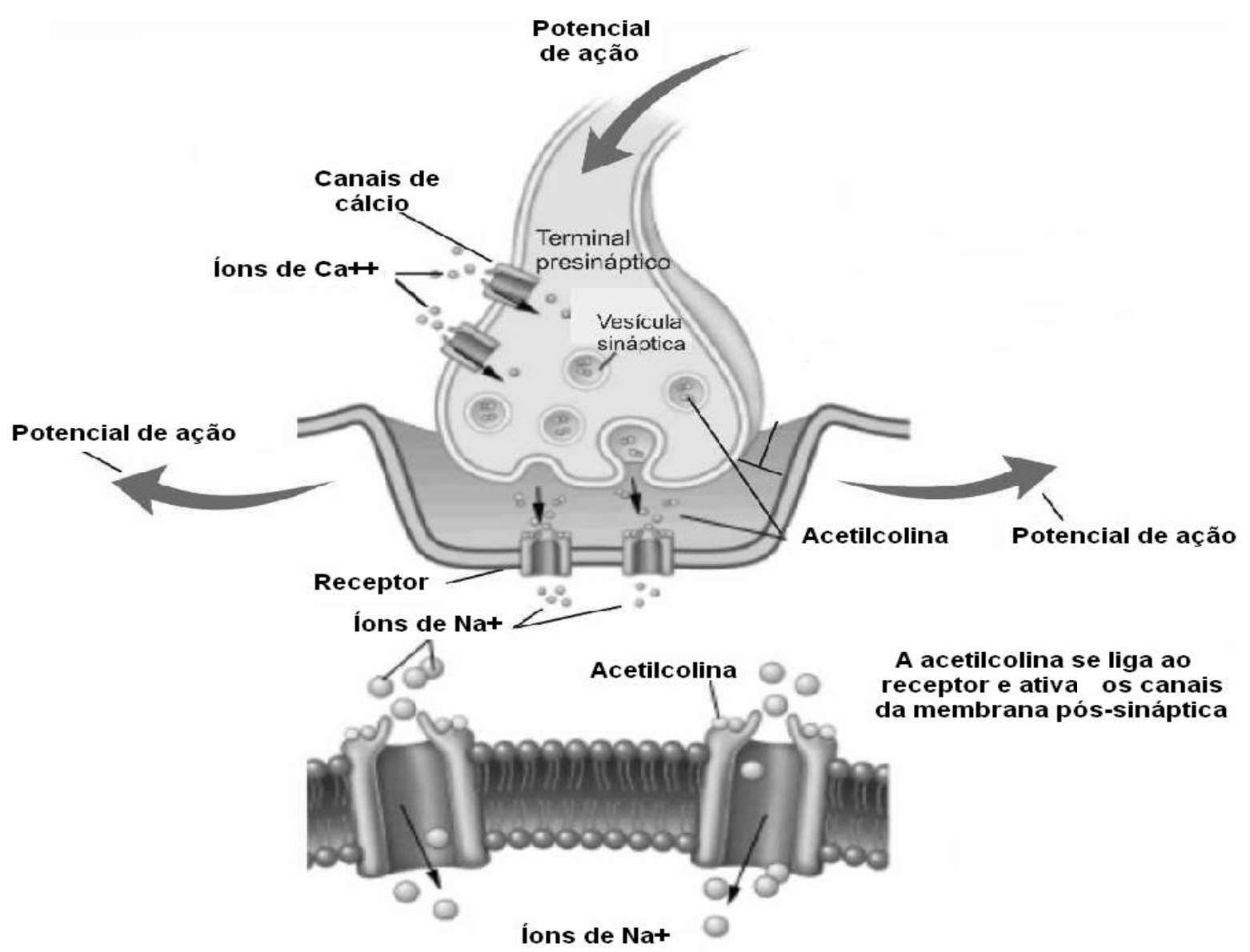

Figura 3: Representação esquemática da microscopia eletrônica da estrutura da junção neuromuscular, apresentando a separação dos elementos pré e pós-sinápticos (Arteaga ${ }^{3}$, 2003).

Rubsamen e cols. (1971) e Hendon \& Fraenkel-Conrat (1971), usando cromatografia de troca iônica, mostraram que a crotoxina é formada por duas subunidades diferentes: uma subunidade básica, com massa molecular de 14,3 $\mathrm{kDa}$ e ponto isoelétrico $(\mathrm{pl})=8,9$; e outra subunidade de caráter ácido cuja massa molecular é de 9,2 $\mathrm{kDa}$ e $\mathrm{pl}=3,8$. A subunidade ácida, também chamada de crotapotina, consiste de 3 cadeias polipeptídicas (A, B e C), ligadas por 7 pontes dissulfeto. A análise de aminoácidos das três frações originadas a partir da redução das pontes dissulfeto indicou que a cadeia $A$ era constituída por 40 resíduos (massa molecular de 4,3 kDa), a cadeia B, 34 resíduos (massa molecular de $3,7 \mathrm{kDa}$ ) e a cadeia $\mathrm{C}$ com 14 resíduos (massa molecular de 1,6 $\mathrm{kDa}$ ). Deste total, 14 resíduos eram meias cistinas, que por sua vez formavam as 7 pontes dissulfeto. 
Segundo o banco de dados Expasy ${ }^{4}$, a sequência da subunidade ácida é composta por 138 aminoácidos, sendo a cadeia A do resíduo 38 ao 77, a cadeia $B$ do resíduo 84 ao 118 e a cadeia $C$ do 125 ao 138 (Figura 4). Embora seja derivada de uma sequência precursora de fosfolipase $A_{2}\left(P\left\llcorner A_{2}\right)\right.$, a crotapotina não apresenta atividade enzimática, e, portanto não possui toxicidade (Aird e cols., 1985). Dentre outros resíduos de aminoácidos, a crotapotina é composta estruturalmente por 2 fenilalaninas (posições: 24 da cadeia A e 2 da cadeia C), 3 tirosinas (posições: 3, 6, 30 da cadeia A) e 1 triptofano (posição 14 da cadeia A).

1

Met Arg Ala Leu Trp lle Val Ala Val Leu Leu Val Gly Val Glu Gly Ser Leu Val Glu 21

Phe Glu Thr Leu Met Met Lys Ile Ala Gly Arg Ser Gly lle Ser Tyr Tyr Ser Ser Tyr 41

Gly Cys Tyr Cys Gly Ala Gly Gly Gln Gly Trp Pro Gln Asp Ala Ser Asp Arg Cys Cys 61

Phe Glu His Asp Cys Cys Tyr Ala!'Lys Leu Thr Gly Cys Asp Pro Thr Thr Asp V'al Tyr 81

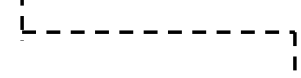

Thr Tyr Arg Gln Glu,Asp!'Gly Glu 'lle Val Cys Gly Glu Asp Asp Pro Cys Gly Thr Gln $1011^{1}$ Ile Cys Glu Cys AspíLys Ala Ala Ala lle Cys Phe Arg Asn Ser Met Asp Thr Tyr Asp 121

Tyr Lys Tyr Leu Gln Phe Ser Pro Glu Asn Cys Gln Gly Glu Ser Gln Pro Cys

Figura 4: Sequência da crotapotina deduzida a partir da sequência da proteína. $O$ peptídeo sinal está sublinhado e as 3 cadeias, A, B e C estão destacadas em amarelo, azul e verde respectivamente. As ligações dissulfídicas também estão identificadas (Expasy, acesso em 15 de setembro de 2009).

A subunidade básica, de cadeia monomérica, exibe sequência similar a de outras fosfolipases $A_{2}$ de venenos de serpentes (Figura 5) (Breithaupt e cols., 1974; Faure \& Bon, 1988). Apresenta em sua estrutura conformacional, dentre outros resíduos, 6 fenilalaninas (posições: 5, 11, 20, 23, 45, e 109), 3 triptofanos (posições: 30, 61 e 80) e 10 tirosinas (posições: 21, 24, 27, 51, 64, 66, 72, 103, 107 e 110). 
1

His Leu Leu Gln Phe Asn Lys Met lle Lys Phe Glu Thr Arg Lys Asn Ala Val Pro Phe 21

Tyr Ala Phe Tyr Gly Cys Tyr Cys Gly Trp Gly Gly Gln Arg Arg Pro Lys Asp Ala Thr 41 1:- -

Asp Arg Cys Cys Phe Val His Asp Cys Cys Tyr Gly 'Lys Leu Thr Lys Cyș Asn Thr Lys

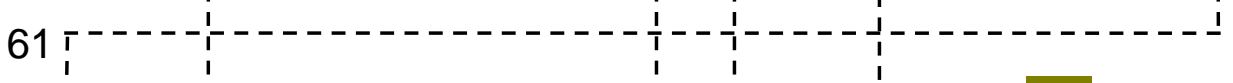

Trp! Asp lle! Tyr Arg Tyr Ser Leu Lys, Ser ;Gly Tyr ! lle Thr Cys Gly Lys Gly Thr Trp 81 '

Cys Lys Glu Gln Ile Cys Glu Cys Asp Arg Val Ala Ala Glu Cys Leu Arg Arg Ser Leu 101

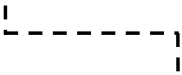

Ser Thr Tyr Lys Asn Glu Tyr Met Phe Tyr Pro Lys Ser Arg Cys Arg Arg Pro Ser Glu 121

Thr Cys

Figura 5: Sequência da $\mathrm{PLA}_{2}$ deduzida diretamente da sequência da proteína. As 7 pontes dissulfeto que estabilizam a conformação estrutural desta subunidade também estão indicadas. (Expasy, acesso em 15 de setembro de 2009).

A crotoxina foi a primeira proteína de veneno de serpente obtida na forma de cristal por Slotta \& Fraenkel-Conrat em 1938, porém a sua recristalização ocorreu apenas em 2007, quando Santos e cols. mostraram relatos cristalográficos por difração de Raios-X do complexo heterodimérico, bem como das suas subunidades isoladas (Figura 6).

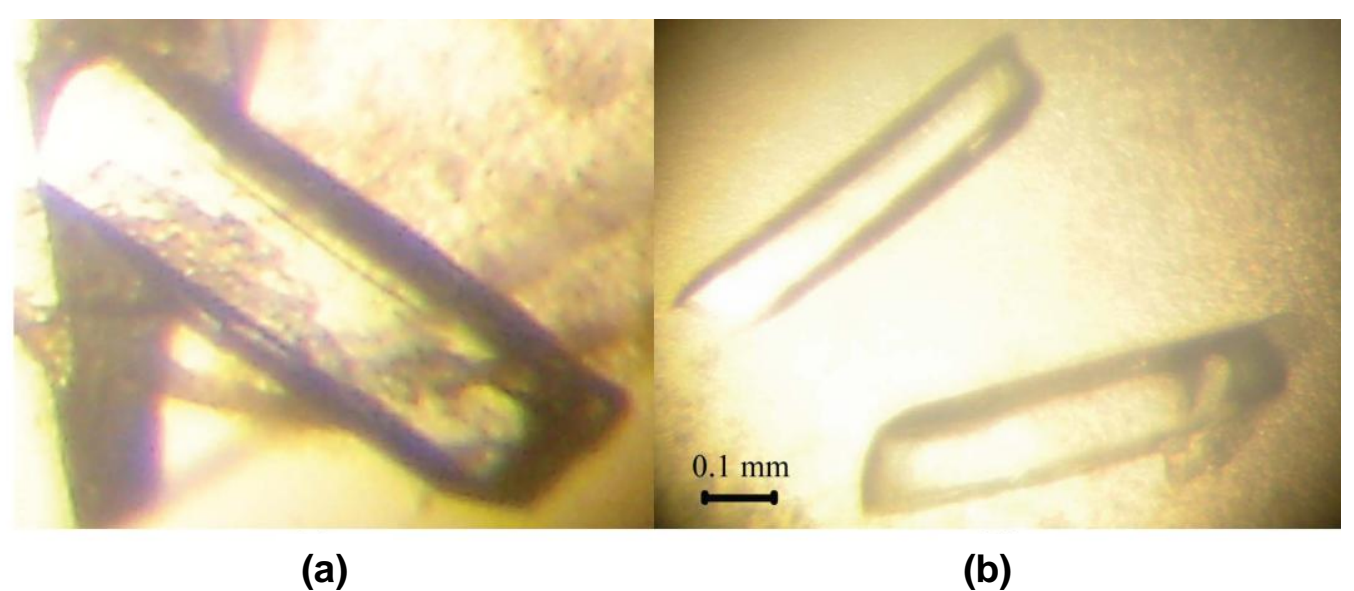

Figura 6: Fotomicrografias de cristais da $\operatorname{PLA}_{2}$ (a) e da crotapotina (b) (Santos e cols., 2007). 
Em 2008, Marchi-Salvador e cols. apresentaram o cristal de um complexo tetramérico formado por 2 dímeros de isoformas (CB1 e CB2) da subunidade básica $\left(\mathrm{PLA}_{2}\right)$ isoladamente. Os resultados obtidos sugerem que este modelo é estável em solução. A estrutura tridimensional do complexo está ilustrada na Figura 7.

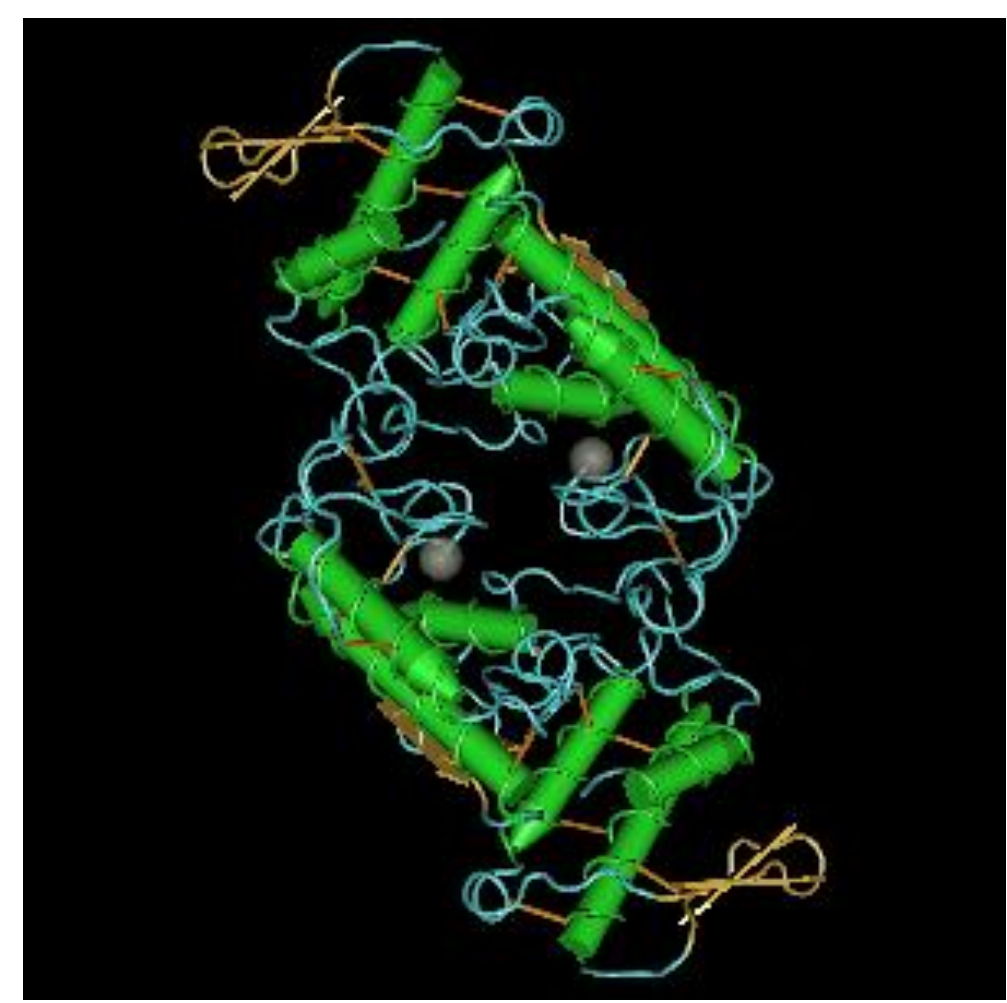

Figura 7: Estrutura tridimensional do complexo tetramérico formado por 2 dímeros de isoformas (CB1 e CB2) da subunidade básica $\left(\mathrm{PLA}_{2}\right)$ isoladamente (Marchi-Salvador, 2008).

O efeito tóxico da crotoxina ocorre a partir de um comportamento sinergético entre as duas subunidades. Assim, a $\mathrm{PLA}_{2}$, quando isolada da crotapotina, é fracamente tóxica e age na junção neuromuscular como a própria toxina, embora doses maiores sejam necessárias para causar o mesmo efeito. Já a crotapotina não é tóxica por si só e não possui ação farmacológica, mas em combinação com a subunidade básica, apresenta eficácia farmacológica ao mesmo tempo em que direciona esta subunidade a junção neuromuscular, potencializando a sua letalidade (Breithaupt, 1976; Hendon \& Fraenkel-Conrat, 
1971; Bon e cols., 1979). Assim, a crotapotina é denominada proteína chaperone, pois teria a função de impedir as ligações inespecíficas da $\mathrm{PLA}_{2}$ na membrana celular, facilitando a manifestação de seus efeitos tóxicos (Bouchier e cols., 1991). Estudos mais recentes mostram que a crotapotina tem um efeito inibitório em edemas de pata de ratos, mionecrose e quebra da membrana lipossômica, induzidos tanto pela atividade catalítica da Asp49, quanto pela ocorrência natural do mutante Lys49 inativo na PLA 2 (Arni e cols., 1995; Murakami \& Arni, 2003; Cecchini e cols., 2004; Santos e cols., 2007).

A crotoxina apresenta várias isoformas que são consequência, muitas vezes, da alteração de um único aminoácido. Esta multiplicidade e a diversidade de tais isoformas parecem ser o resultado de modificação pós-traducional da proteína. A crotoxina então é uma mistura de variantes, derivadas da combinação das isoformas das subunidades (Faure \& Bon, 1988; Faure e cols., 1993). As isoformas da crotapotina consistem em 3 cadeias polipeptídicas $(\alpha, \beta, \gamma)$ ligadas por pontes dissulfeto resultantes de diferentes clivagens proteolíticas sobre uma única forma precursora (Bouchier e cols., 1991). As isoformas de PLA também podem ser observadas durante a expressão de diferentes RNAs mensageiros presentes numa mesma serpente (Faure e cols., 1994). Tais isoformas de um mesmo veneno exibem diferentes efeitos farmacológicos.

Nos últimos anos, as pesquisas sobre $\mathrm{PLA}_{2}$ têm sido impulsionadas principalmente pelo seu importante papel em várias atividades biológicas, como as apresentadas abaixo:

- Neurotoxicidade: neurotoxinas pré e pós-sinápticas;

- Miotoxicidade: mionecrose local e miotoxicidade sistêmica;

- Cardiotoxicidade: efeito anticoagulante, iniciador da agregação plaquetária, inibidor da agregação plaquetária;

- Atividade hemolítica: hemorragia interna, atividade antihemorrágica, atividade convulsionante, atividade hipotensiva, atividade edematogênica, lesão de órgãos e tecidos (Kini, 1997). 
No caso específico da associação destas $\mathrm{PLA}_{2}$ com outras $\mathrm{PLA}_{2}$ (ou moléculas do tipo $\mathrm{PLA}_{2}$, como ocorre com a crotoxina), ou ainda com outras proteínas para formar complexos, observa-se, na grande maioria dos casos, que a letalidade do veneno é potencializada. Assim, é de grande importância o entendimento da estrutura e da função destes complexos para promover uma melhor compreensão da toxicidade do veneno (Doley \& Kini, 2009).

A crotamina foi primeiramente isolada, por meio de métodos eletroforéticos, por Gonçalves \& Vieira (1950). Possui massa molecular de 4,8 kDa, é composta por 42 aminoácidos (Laure, 1975), apresentando, dentre outros resíduos, 7 resíduos de aminoácidos aromáticos: 1 tirosina, 2 histidinas, 2 triptofanos e 2 fenilalaninas (Tabela 1).

Tabela 1: Composição de aminoácidos da crotamina.

\begin{tabular}{llll}
\hline 9 Lisinas & 3 Serinas & 2 Histidinas & 1 Isoleucina \\
6 Cisteínas & 2 Argininas & 2 Triptofanos & 1 Leucina \\
5 Glicinas & 2 Aspartato & 1 Glutamato & 1 Metionina \\
3 Prolinas & 2 Fenilalaninas & 1 Glutamina & 1 Tirosina \\
\hline
\end{tabular}

É uma toxina extremamente básica, com pl = 10,3 (Gonçalves, 1956). A presença de 6 cisteínas ligadas por pontes dissulfeto confere à crotamina alta estabilidade conformacional (Hampe e cols., 1978). O N-terminal é a tirosina e o C-terminal é a glicina (Boni-Mitake e cols., 2001). Na Figura 8 é possível observar a sequência da estrutura primária da crotamina com a indicação das 3 pontes dissulfeto formadas. 


\section{1}

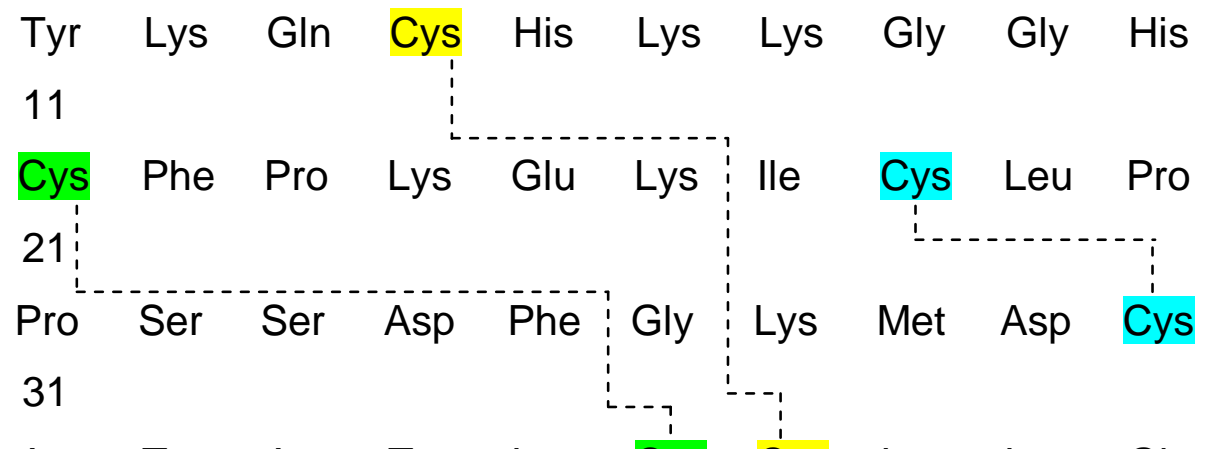

Arg Trp Arg Trp Lys Cys Cys Lys Lys Gly 41

Ser Gly

Figura 8: Sequência de aminoácidos da crotamina com indicação das pontes dissulfeto (Beltran e cols., 1990).

Após a determinação da sequência primária da crotamina (Laure, 1975), várias miotoxinas básicas têm sido descritas e sequenciadas: crotamina-lle 19 (dos Santos e cols., 1993), miotoxina a (Fox e cols., 1979), miotoxinas I e II (Engle e cols., 1983) e outras. Essa família é única, não sendo encontrada nenhuma homologia com outras proteínas já descritas (Oguiura, 1998). A crotamina pertence então a uma família de pequenas miotoxinas básicas que possuem a mesma estrutura, a mesma ação e estão presentes em outros venenos de cascavéis (Bober e cols., 1988).

Gonçalves \& Arantes (1956) mostraram que a quantidade de crotamina no veneno de cascavel é extremamente variável perfazendo de 9,6 a 53,7\% do veneno total. A constituição do veneno de C.d.terrificus, devido à presença de crotamina pode ser denominada crotamina-positiva ou crotamina-negativa. As serpentes que possuem venenos crotamina-positiva podem ser encontradas ao oeste do Estado de São Paulo e os venenos crotamina-negativa, ao leste do Estado, tendo ainda uma região que é híbrida, na qual coexistem ambos os tipos de veneno (Schenberg, 1959; Oguiura, 1998).

Sabe-se que a ação miotóxica da crotamina causa paralisia dos membros posteriores, contratura dos membros anteriores e dificuldade respiratória em alguns animais, como camundongo, coelho e rato. A crotamina age especificamente no canal de sódio do músculo esquelético ou em seu 
modulador, induzindo um influxo de sódio pela abertura do receptor de rianodina (Cheymol e cols., 1971; Chang \& Tseng, 1978; Vital Brazil e cols., 1979). Estudos recentes mostram que a toxina parece alterar o influxo de íons $\mathrm{Ca}^{2+}$ no retículo sarcoplasmático (Fletcher e cols., 1996; Omby, 1998). Rizzi e cols. (2007) demonstraram a partir do mecanismo de ação biológica da crotamina, que esta toxina afeta os canais iônicos de maneira indireta. Tal estudo mostrou ainda que a crotamina age de maneira diferente em músculos fast e slow-twitching, apresentando preferência por inativar o fast-twitching. Na Figura 9 pode-se observar o efeito paralisante da crotamina em camundongo.

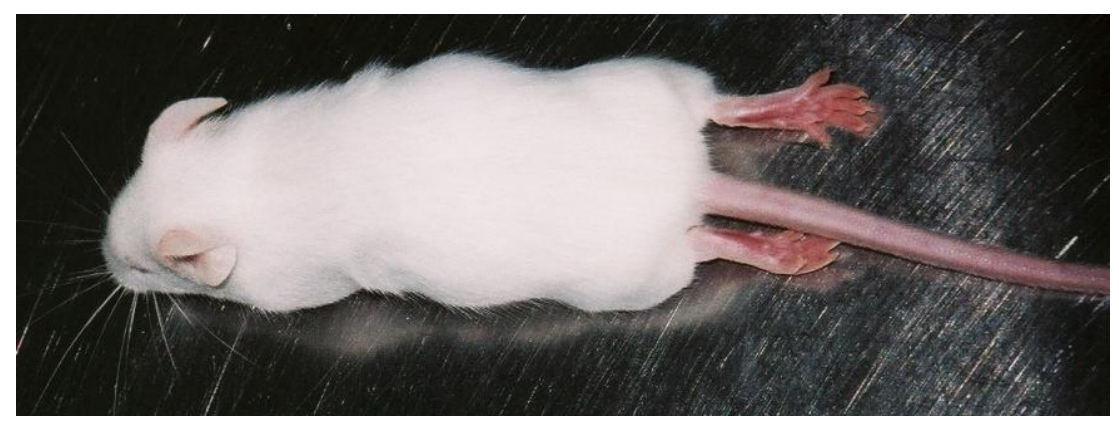

Figura 9: Efeito da crotamina nos membros posteriores quando injetada de forma intraperitoneal (Casare, 2009).

Toyama e cols. (2000) isolaram duas isoformas da crotamina denominadas F2 e F3. Essas isoformas isoladas possuem estrutura tridimensional idênticas, diferenciando apenas 1 ou 2 resíduos de aminoácidos. Ambas as isoformas produziram paralisia espásticas em camundongo e a DL50 para as duas foi igual a $0,5 \mathrm{mg} / \mathrm{kg}$ de camundongo. Por outro lado apenas a isoforma F2 afetou a secreção de insulina em ilhota de rato.

Estudos relacionados à estrutura da crotamina incluem espectroscopia Raman (Kawano e cols., 1982), espalhamento de Raios-X a baixo ângulo - SAXS (Beltran e cols., 1985, 1990), ressonância magnética nuclear homonuclear $-{ }^{1} \mathrm{H}$ RMN (Endo e cols., 1989; Nicastro e cols., 2003), modelagem computacional (Siqueira e cols., 2002) e ressonância magnética nuclear - RMN (Fadel, 2005).

Endo e cols. (1989) sugerem que a crotamina apresenta dois estados estruturais diferentes em solução. Essas estruturas coexistem e podem refletir isômero cis-trans dos resíduos de prolina ou pode ocorrer uma dimerização da 
molécula com uma ponte dissulfeto intermolecular fazendo a ligação entre as duas subunidades.

Por meio da modelagem computacional, Siqueira e cols. (2002) propõem uma estrutura estável composta por duas folhas $\beta$ e regiões aleatórias. Estes resultados estão em contradição a resultados antes obtidos, uma vez que se acreditava na instabilidade conformacional da crotamina.

Nicastro e cols. (2003) apresentam uma estrutura tridimensional resolvida por ${ }^{1} \mathrm{H}$-RMN composta por três segmentos de folha $\beta$ e o $\mathrm{N}$-terminal estruturado como $\alpha$-hélice, interligados por estrutura aleatória.

Fadel (2005), utilizando a técnica de RMN apresentou resultados coincidentes com a estrutura proposta por Nicastro e cols. (2003), embora em condições amostrais diferentes. Tais diferenças se mostram relevantes, sobretudo em relação à estrutura secundária, uma vez que na estrutura publicada por Nicastro, a crotamina apresenta topologia do tipo $\alpha \beta_{1} \beta_{2} \beta_{3}$. Já no trabalho de Fadel, a conformação de folha $\beta_{3}$ não está bem identificada e a topologia proposta foi do tipo $\alpha \beta_{1} \beta_{2}$. Além disso, os espectros apresentaram isoformas, porém não apresentaram isomerização cis-trans para prolina como havia sugerido Endo e cols. (1989). A Figura 10 ilustra a estrutura tridimensional para a crotamina proposta por Fadel (2005):

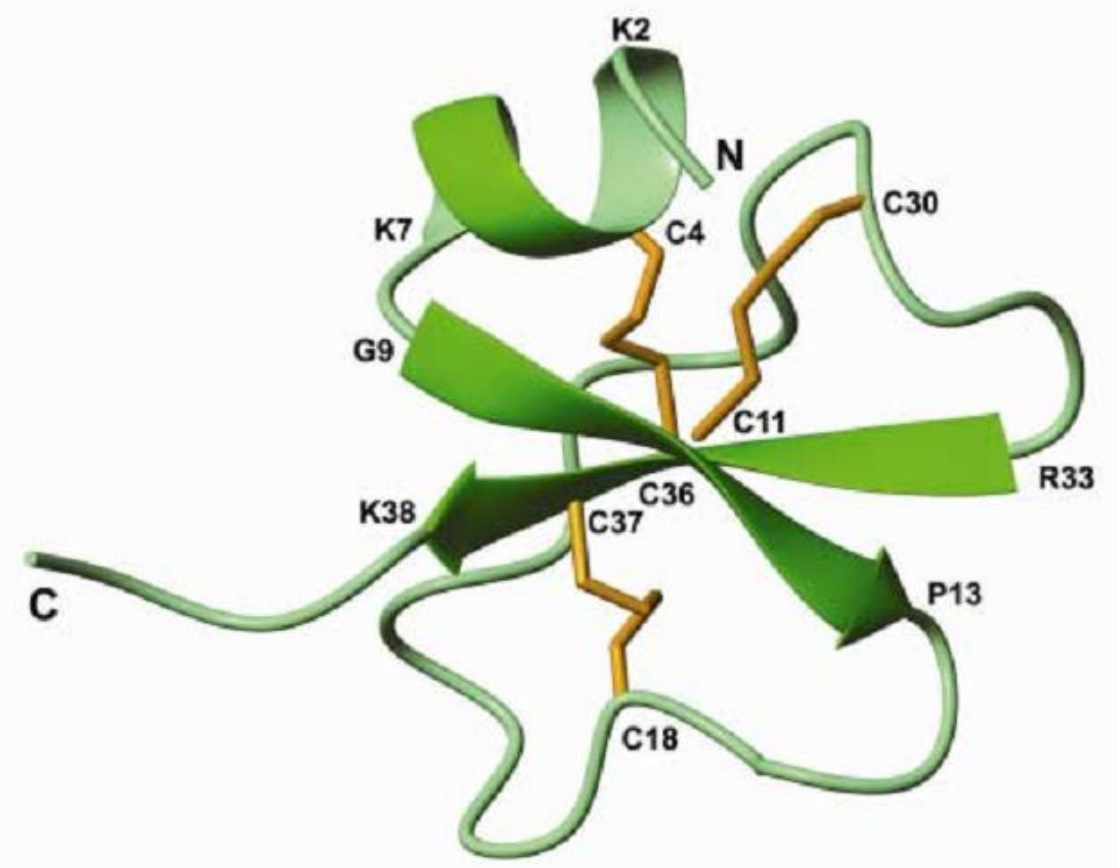

Figura 10: Estrutura tridimensional da crotamina resolvida por RMN (Fadel, 2005). 


\subsection{Radiação lonizante}

A radiação ionizante consiste de ondas eletromagnéticas formadas a partir de transições nucleares, tendo alta energia, ausência de massa (no caso da radiação gama), bem como a capacidade de promover ionização e excitação nos meios, possuindo um alto poder de penetração (Grosh \& Hoopywood, 1979). No processo de excitação, um elétron do átomo adquire energia do fóton, passando para um nível quântico superior, permanecendo em órbita ao redor do núcleo. Já na ionização, a energia adquirida pelo elétron é suficiente para que ele seja projetado da eletrosfera, ionizando o átomo (Figura 11). Como resultado desta ionização, o átomo passa a ter um elétron desemparelhado em um de seus orbitais superiores, tornando-se altamente reativo. O radical livre assim formado tem meia vida curta e, em picossegundos, combina seu elétron desemparelhado com um elétron de outro átomo, ejeta seu elétron ou ainda, captura um elétron de outro átomo.

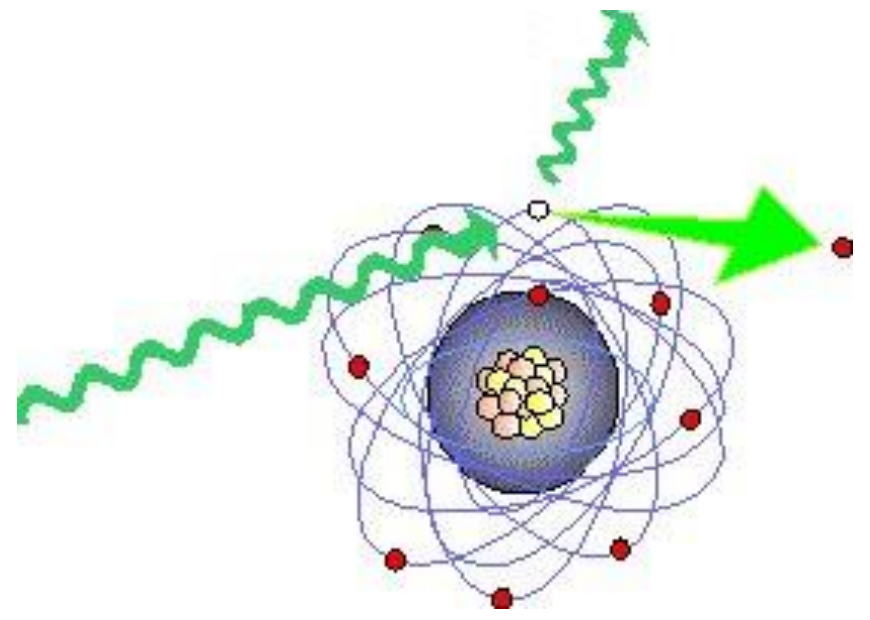

Figura 11: Processo de ionização atômica. A energia que atinge a eletrosfera pode ser suficiente para ejetar um elétron da sua camada de valência, tornando o átomo ionizado (International Agency of Energy Atomic ${ }^{5}$ ).

No que diz respeito à ação da radiação em materiais biológicos, o processo é iniciado por várias interações físicas, que dependem dos átomos presentes e da natureza química do sistema (Butler e cols., 1984). 
Seus efeitos podem ser diretos ou indiretos, sendo o primeiro uma consequência da interação direta com componentes celulares como o DNA, proteínas e lipídeos, provocando alterações estruturais em suas moléculas. $O$ efeito direto constitui cerca de $30 \%$ do efeito biológico total das radiações. Já o efeito indireto se dá quando a radiação interage com as moléculas de água presentes no meio intracelular, formando os chamados produtos da radiólise da água $(\mathrm{OH} \bullet, \mathrm{H} \bullet$, elétron aquoso e outros). Este efeito, denominado radiólise da água, corresponde à cerca de $70 \%$ do efeito biológico produzido pelas radiações e sua maior ocorrência, deve-se ao fato de a água ocupar grande parte da composição celular (Michaels \& Hunt, 1978). As equações abaixo resumem as principais espécies moleculares e radicais livres produzidos na radiólise da água:

1) $\mathrm{H}_{2} \mathrm{O} \Rightarrow \mathrm{H}_{2} \mathrm{O}^{\bullet}+\mathrm{e}^{-}$

2) $\mathrm{H}_{2} \mathrm{O}^{\bullet}+\mathrm{H}_{2} \mathrm{O} \Rightarrow \mathrm{H}_{3} \mathrm{O}^{+}+\mathrm{OH}^{\bullet}$

3) $e^{-}+a q \Rightarrow e^{-} a q$

Após a formação de tais espécies, podem ocorrer ainda reações entre as mesmas, segundo as equações abaixo:

4) $2 \mathrm{OH}^{\bullet} \Rightarrow \mathrm{H}_{2} \mathrm{O}_{2}$

5) $\mathrm{OH}^{\circ}+\mathrm{e}^{-} \mathrm{aq} \Rightarrow \mathrm{OH}^{-}$

6) $2 \mathrm{e}^{-} \mathrm{aq}+2 \mathrm{H}_{2} \mathrm{O} \Rightarrow \mathrm{H}_{2}+2 \mathrm{OH}^{-}$

Esses produtos da radiólise da água passam por uma variedade de reações, incluindo a abstração de hidrogênio, transferência de elétrons (oxidação ou redução do substrato), adição, fragmentação e rearranjo, dimerização e substituição de aminoácidos, peptídeos e proteínas (Hawkins \& Davies, 2001).

Com radiações de baixa transferência de energia (raios gama, raios- $X$ de alta energia, elétrons de $2 \mathrm{MeV}$ ), a maioria das ionizações é isolada, de maneira que $\mathrm{OH}^{\bullet}$ e e $\mathrm{e}^{-}$aq são as espécies principais quando a irradiação ocorre em solução aquosa. Essas espécies são respectivamente poderosos agentes 
oxidantes e redutores. Os radicais hidroxil reagem com velocidades diferentes com os aminoácidos, dependendo da natureza e tamanho de sua cadeia lateral. Com cadeias alifáticas (abertas), a principal reação é a abstração de um hidrogênio do carbono alfa. Esta reatividade depende diretamente do comprimento da cadeia lateral, sendo maior a velocidade de reação quanto maior o tamanho da cadeia. Com aminoácidos cuja cadeia lateral encerra um grupamento aromático, as reações ocorrem principalmente no anel (Butler e cols., 1984; Berlett \& Stadtman, 1997).

Ao reagir com cisteína, o radical hidroxil abstrai o hidrogênio da sulfidrila gerando o radical $\mathrm{SR}^{\circ}$ que pode reagir posteriormente para formar radicais do tipo RSSR, podendo levar a formação de pontes S-S inter e intra cadeias.

O elétron aquoso, por sua vez, atua na desaminação dos aminoácidos. Esta reação é dependente do estado de protonação do grupamento amino terminal, sendo mais eficiente quando a amina está protonada. Aminoácidos que apresentam aminas épsilon são passíveis de desaminação neste carbono e os grupamentos aromáticos também apresentam alta capacidade de reagir com o elétron aquoso.

A velocidade de reação do elétron aquoso é muito maior com peptídeos do que com aminoácidos isolados em decorrência da eletrofilicidade da ligação peptídica (Butler e cols., 1984).

No caso específico das proteínas em solução aquosa, a radiação pode induzir uma série de alterações na estrutura protéica e por consequência, nas propriedades físico-químicas desta, indo desde simples ionizações, até alterações drásticas na sua estrutura primária. Além disso, alterações oxidativas decorrentes da interação dos radicais livres primários com a molécula de proteína podem conferir cargas negativas à mesma (Wales \& Kusel, 1992). A desaminação da cadeia protéica também é observada após o processo de irradiação (Butler e cols., 1987; Garrison, 1987). Apesar de estes efeitos ocorrerem ao acaso, alguns sítios podem ser mais favoráveis, devido à transmissão de energia intramolecular. Estas mudanças estão relacionadas com a perda da atividade biológica, além de poder interferir nas propriedades imunológicas. 
Existem indicações de uma diferença quanto à radiossensibilidade dessas várias funções biológicas, sendo as propriedades imunológicas as mais radiorresistentes (Guarnieri, 1992).

No caso da proteína de interesse ser tóxica para as células hospedeiras, a atenuação da toxicidade por radiação apresenta-se como uma ótima ferramenta, uma vez que além de diminuir a toxicidade, o método também se mostra eficiente na produção de melhores imunógenos, somado a vantagem de não adicionar novas moléculas à amostra de interesse, como ocorre em outras metodologias: a incubação com formaldeído (Costa e cols., 1985), glutaraldeído (Guidolin e cols., 1989) ou carboximetil-celulose (Moroz e cols., 1963), a adsorção com tanino (Okonogi e cols., 1979), a inativação térmica (Relyveld e cols., 1974), o uso de inibidores de sítio ativo (Higashi e cols., 1989), iodação (Heneine e cols., 1988) e demais agentes físicos ou químicos (Grasset, 1945). Outros trabalhos mostraram ainda que a radiação pode melhorar a antigenicidade de muitas proteínas (Okonogi e cols., 1979; Pinho e cols., 1995; Nascimento e cols., 1996).

Uma possível aplicação do efeito da radiação ionizante em toxinas animais, especificamente toxinas de serpentes, está na produção do soro antiofídico, que ainda hoje se mostra como único método terapêutico em caso de acidentes (Calmette, 1907).

A produção de soro no Brasil utiliza equinos que, apesar do grande porte, sofrem com a injeção do veneno apresentando diminuição da longevidade quando comparado com os cavalos não imunizados (Rosenfeld, 1971). Assim, diminuir a toxicidade do veneno poderia significar um aumento na sobrevida do animal soroprodutor após o processo de imunização, uma vez que a produção de anticorpos acontece da mesma forma ou de maneira mais eficiente quando a proteína é submetida à radiação ionizante.

O grupo de venenos do Centro de Biotecnologia do IPEN já obteve resultados muito importantes quanto à utilização da radiação ionizante na destoxicação de venenos de serpentes (Andriani, 1995; Guarnieri, 1992; Murata, 1988; Nascimento, 1991/1995; Spencer, 1995/1999). O isolamento das frações protéicas também já se mostrou como grande estratégia na obtenção de um maior detalhamento quanto à ação da radiação sobre as proteínas do veneno total, já que quando há uma mistura protéica, as diversas espécies em solução 
atuam como aceptores dos radicais livres, acarretando um fenômeno de proteção mútua (Skalka \& Antoni, 1970; Nascimento e cols., 1996; Spencer, 1999; Casare, 2009; Baptista, 2004).

Apesar do enorme avanço sobre os estudos do efeito da radiação em proteínas, pouco se sabe sobre a estrutura conformacional de proteínas ofídicas que são submetidas à ação da radiação ionizante. Assim, a utilização de metodologias mais precisas e que proporcionem maior riqueza de informações como as atuais, contribuirão sobremaneira para o conhecimento das propriedades estruturais de toxinas modificadas pela radiação. 


\section{OBJETIVOS}

\section{Geral:}

Avaliar modificações estruturais causadas pela radiação ionizante nas principais toxinas do veneno de cascavel, crotamina e crotoxina.

\section{Específicos:}

- Purificar a crotamina e a crotoxina a partir do veneno bruto da Crotalus durissus terrificus, utilizando técnicas cromatográficas;

- Estudar a estrutura conformacional da crotamina e da crotoxina, ambas nas formas nativa e irradiada, por meio das técnicas de Fluorescência, Dicroísmo Circular, Calorimetria Diferencial e Espectroscopia de Infravermelho. 


\section{MATERIAL E MÉTODOS}

O veneno de C.d.terrificus utilizado para os experimentos realizados neste trabalho foi gentilmente cedido pelo Centro de Estudo de Venenos e Animais Peçonhentos - CEVAP, situado na cidade de Botucatu.

Todos os reagentes utilizados na realização dos experimentos foram de qualidade pró análise. A água utilizada para o preparo das soluções foi procedente de um sistema Milli $Q$.

\subsection{Isolamento das toxinas}

A cromatografia é uma técnica físico-química de grande importância na separação de misturas e identificação de seus componentes. Está fundamentada na migração diferencial dos componentes de uma mistura, que ocorre devido a diferentes interações, entre duas fases imiscíveis, a fase móvel e a fase estacionária (fixa). A grande variedade de combinações entre fases móveis e estacionárias a torna uma técnica extremamente versátil e de grande aplicação (Bastos, 2008).

De uma forma geral, pode-se classificar a cromatografia em: planar e em coluna. No primeiro caso estão a Cromatografia em Papel - CP, a Cromatografia em Camada Delgada - CCD e a Cromatografia por Centrifugação - Cromatotron. No segundo caso estão as Cromatografias Líquidas - CL, Gasosa - CG e Supercrítica - CSC. A cromatografia Líquida divide-se ainda em Clássica e de Alta Eficiência, sendo a primeira realizada em pressão atmosférica e a segunda com o auxílio de bombas de alta pressão.

Quanto ao modo de separação, a cromatografia pode ser dividida em adsorção, partição, troca iônica, exclusão molecular ou ainda a mistura desses mecanismos (Degani e cols., 1998).

Em relação à exclusão molecular, também chamada de filtração em gel, o princípio de separação está fundamentado na diferença entre o tamanho das moléculas ou componentes da mistura, sendo que os solutos maiores passam com maior velocidade pela coluna. No caso ideal da exclusão molecular, ao 
contrário de outras técnicas cromatográficas, não há interações atrativas entre a fase estacionária e o soluto. De forma mais exata, a fase móvel passa por meio de um gel poroso, cujos poros são suficientemente pequenos para excluírem as moléculas maiores de soluto, mas não as menores. $O$ fluxo de moléculas grandes passa sem entrar pelos poros do gel, enquanto as moléculas pequenas levam mais tempo para atravessarem a coluna, pois penetram no gel e precisam fluir por um volume maior até saírem do mesmo.

No caso da cromatografia de troca iônica, íons, ânions ou cátions, estão ligados covalentemente à fase estacionária sólida (resina). Os íons do soluto, com carga oposta são atraídos para a fase estacionária por forças de natureza eletrostática. A configuração eletrônica dos compostos será alterada de acordo com o pH da solução (Bastos, 2008).

Outro tipo de cromatografia, muito aplicada em separações analíticas, é denominada cromatografia de fase reversa. Neste método a fase estacionária possui menor polaridade em comparação à fase móvel, portanto, os compostos com maior polaridade são os primeiros a saírem da coluna.

\subsubsection{Cromatografia de exclusão molecular}

A crotamina e a crotoxina foram inicialmente isoladas, a partir do veneno bruto de C.d.terrificus, por meio de exclusão molecular em coluna de gel filtração Superdex G-75 (1,6 x $70 \mathrm{~cm})$. Em cada cromatografia, cerca de $80 \mathrm{mg}$ do veneno total liofilizado foram dissolvidas em 1,0 $\mathrm{mL}$ de tampão formiato de amônio $100 \mathrm{mM}, \mathrm{pH}$ 3,0. A seguir a solução foi centrifugada a $14000 \mathrm{~g}$ por 5 minutos em uma microcentrífuga. O sobrenadante foi aplicado à coluna de gel filtração, já ambientada em mesmo tampão, com fluxo de $0,5 \mathrm{~mL} / \mathrm{min}$. As frações foram coletadas $(1,0 \mathrm{~mL}$ por tubo) com o auxílio de um coletor automático do próprio sistema de FPLC (Fast Protein Liquid Chromatography). Toda a eluição foi acompanhada pela leitura da absorvância a $280 \mathrm{~nm}$ em um espectrofotômetro. As frações de interesse foram separadas em recipiente adequado e posteriormente liofilizadas. Para compor este trabalho, uma das cromatografias de exclusão molecular foi realizada em sistema HPLC (High Performance Liquid 
Chromatography), o que permitiu uma visão mais detalhada do fracionamento do veneno total.

\subsubsection{Cromatografia de troca iônica}

A fração correspondente à crotoxina obtida na primeira etapa cromatográfica, após liofilização, foi ressuspendida em 3,0 mL de tampão Tris/ $\mathrm{HCl}, 50$ mM, pH 8,2 (tampão A) e aplicada em uma coluna de troca aniônica do tipo Mono Q, previamente estabilizada em mesmo tampão, conectada a um sistema de HPLC. A crotoxina adsorvida à coluna foi eluída pela passagem de um gradiente linear de $\mathrm{NaCl}$, de 0 a $1 \mathrm{M}$, em tampão idêntico ao $\mathrm{A}$, exceto pela adição do sal. A absorvância foi verificada automaticamente em $280 \mathrm{~nm}$. As frações correspondentes à crotoxina foram coletadas e dialisadas contra água em membrana apropriada (limite máximo de $12000 \mathrm{Da}$ - SIGMA-ALDRICH ${ }^{\circledR}$ ) e de forma exaustiva ( 3 trocas no volume de $2 \mathrm{~L}$ cada). Em seguida a crotoxina foi liofilizada e mantida em freezer a temperatura de $-20 \stackrel{\circ}{\circ}$.

A fração correspondente à crotamina, também já liofilizada, foi ressuspendida em tampão fosfato de sódio 50 mM, pH 7,8 (tampão A) e aplicada em uma resina do tipo Resource $S$ (troca cationica), em sistema HPLC, estabilizada no mesmo tampão. Após a adsorção da proteína, esta foi eluída com gradiente linear de salina, de 0 a $2 \mathrm{M}$ de $\mathrm{NaCl}$ (tampão $\mathrm{A}+2 \mathrm{M}$ de $\mathrm{NaCl}$ ). Verificou-se a absorvância em $280 \mathrm{~nm}$ durante todo o processo cromatográfico. Posteriormente a crotamina foi dialisada em membrana adequada (limite máximo de $3000 \mathrm{Da}$ - SIGMA $^{\circledR}$ ), contra água e de maneira exaustiva (3 trocas no volume de $2 \mathrm{~L}$ cada). Após a liofilização, a crotamina foi armazenada em freezer a -20 $\stackrel{\circ}{ } \mathrm{C}$.

\subsubsection{Cromatografia de exclusão molecular de alta eficiência (HPSEC)}

A cada fase cromatográfica, foram aliquotados $200 \mathrm{~mL}$ das frações de interesse (crotoxina e crotamina) para realização de cromatografia de exclusão molecular de alta eficiência em coluna de gel filtração analítica (Superdex 75 10/300 GL), conectada ao sistema de HPLC. 
Para a primeira análise, a coluna de gel filtração foi ambientada em tampão formiato de amônio $100 \mathrm{mM}, \mathrm{pH}$ 3,0, tanto para a aplicação da crotamina como da crotoxina. Após a passagem de 3 vezes o volume da coluna, cerca de $100 \mu \mathrm{L}$ das amostras foram então aplicados no mesmo fluxo de equilíbrio da coluna. O perfil cromatográfico obtido foi monitorado pela leitura da absorvância a $280 \mathrm{~nm}$ em um espectrofotômetro acoplado ao próprio sistema.

$\mathrm{Na}$ segunda análise, as condições cromatográficas citadas acima foram mantidas, porém as alíquotas de $100 \mu \mathrm{L}$ de crotamina e crotoxina injetadas no sistema eram referentes à segunda etapa de isolamento para cada uma das proteínas, troca catiônica e troca aniônica respectivamente. Neste caso o perfil cromatográfico também foi acompanhado por medidas de absorvância a $280 \mathrm{~nm}$.

Esta técnica analítica foi utilizada para verificação da pureza protéica após cada fase cromatográfica.

\subsubsection{Cromatografia de fase reversa (RP-HPLC)}

Após a troca catiônica, segunda etapa de isolamento para a crotamina, foi realizada uma cromatografia de fase reversa na tentativa de separar as isoformas desta toxina, comprovando dados existentes na literatura.

Para a execução do método utilizou-se uma coluna de fase reversa C-8. Inicialmente a coluna foi ambientada com $0,05 \%$ de ácido fórmico e após a injeção da amostra, passou-se um gradiente de 0 a $100 \%$ de acetonitrila (grau HPLC) para eluir a proteína em questão. Durante toda a corrida cromatográfica a leitura da absorvância foi monitorada a $280 \mathrm{~nm}$ em espectrofotômetro acoplado ao sistema. Os picos de interesse foram coletados e congelados em freezer $-20 \stackrel{\circ}{C}$ para possíveis análises posteriores.

\subsubsection{Cromatografia de exclusão molecular (desalting)}

Em decorrência da perda de crotamina na diálise por meio do uso de membrana aparentemente adequada para tal processo, optou-se por realizar uma gel filtração, neste caso também chamada de desalting, cujo poro da resina 
Sephadex G-10 permite a separação entre componentes iônicos (baixa massa molecular) e os que apresentam maior massa molecular.

Para a realização do método, a coluna de desalting, conectada ao sistema HPLC, foi ambientada em tampão formiato de amônio, 100 mM, pH 3,0. Posteriormente a amostra de crotamina proveniente da troca catiônica foi aplicada à coluna e a sua eluição foi monitorada a $280 \mathrm{~nm}$. A condutividade neste caso também foi averiguada durante toda a cromatografia.

\subsection{Dosagem protéica}

A determinação da concentração protéica da crotamina e da crotoxina foi realizada a partir dos valores dos coeficientes de extinção obtidos no Expasy que relaciona a concentração protéica com a leitura espectrofotométrica em 280 nm. Esta relação provém da Lei de Lambert-Beer que pode ser escrita da seguinte maneira:

\section{$A=\varepsilon \mathbf{c} b$}

Em que A é a medida da absorvância em $280 \mathrm{~nm}$ da região ultravioleta do espectro eletromagnético; $\boldsymbol{\varepsilon}$ é a absortividade molar; c é a concentração do soluto [mols/L] e b é o comprimento do caminho óptico através da amostra [cm].

A leitura é realizada em $280 \mathrm{~nm}$, pois nesta região do espectro é possível traduzir as bandas relativas aos cromóforos das cadeias laterais dos seguintes aminoácidos: Triptofano (Trp), Tirosina (Tyr) e Fenilalanina (Phe), bem como das pontes dissulfeto. Além destas bandas, também é possível traduzir a contribuição de outros aminoácidos não aromáticos: Metionina (Met), Cisteína (Cys) e Histidina (His) além dos grupamentos sulfidrilas livres.

\subsection{Irradiação das proteínas}

A crotamina e a crotoxina em solução salina, ambas na concentração de $2 \mathrm{mg} / \mathrm{mL}$, foram irradiadas com raios gama provenientes de uma fonte de ${ }^{60} \mathrm{Co}$ (Gammacell 220, da Atomic Energy of Canada Limited), a temperatura ambiente e 
na presença de oxigênio atmosférico. A dose total foi de 2 kGy e a taxa de dose de 2,09 kGy/h. Esta dose de radiação foi estabelecida por trabalhos prévios realizados em nosso laboratório que mostraram a diminuição da toxicidade do veneno de C.d.terrificus e suas frações, sem perda da capacidade imunogênica (Nascimento e cols., 1996).

\subsection{Análise de Fluorescência}

A Fluorescência é uma técnica relevante quanto à indicação de alterações estruturais em moléculas protéicas, principalmente em relação aos compostos aromáticos.

\subsubsection{Princípio de análise por Fluorescência}

A absorção da radiação eletromagnética de um determinado comprimento de onda por um cromóforo faz com que seus elétrons passem do estado eletrônico fundamental para o excitado. A fluorescência ocorre quando esse elétron retorna ao seu local original, emitindo um fóton (Casare, 2009).

No caso das proteínas, há apenas 3 tipos de resíduos de aminoácidos, ditos aromáticos, que podem ser responsáveis pela formação de um espectro de fluorescência: o Triptofano, a Tirosina e a Fenilalanina. Quando tais resíduos são excitados por radiação ultravioleta, os elétrons transferidos a níveis mais energéticos retornam ao estado fundamental por meio da emissão de fluorescência. Tal processo é composto por duas etapas: a primeira é via dissipação não radioativa e a segunda via decaimento radioativo exponencial do fluoróforo, sendo considerada então uma emissão fluorescente intrínseca à proteína (Chen e cols., 1969).

A primeira etapa traduz uma transferência de energia não radioativa de acordo com os seguintes mecanismos: processo de colisão com outras moléculas, transições diversas sem emissão, reorientação do fluoróforo ou da molécula como um todo, além da transferência de calor propriamente dita. A segunda etapa (decaimento exponencial) engloba os seguintes aspectos: transferência de energia entre os fluoróforos (dependendo da geometria 
molecular, separação e orientação das moléculas); supressão (quenching) com outras moléculas ou íons (dependendo do acesso do fluoróforo na estrutura molecular); cinética de declínio da emissão fluorescente e grau de despolarização da radiação emitida.

Assim, é possível distinguir de forma quantitativa os fluoróforos intrínsecos, embora o processo de transferência de energia entre os mesmos não possa ser descartado (Chen e cols., 1969).

\subsubsection{Procedimento para análise de Fluorescência}

As amostras de crotamina e de crotoxina, na forma nativa e irradiada, foram submetidas à análise das alterações intrínsecas, na concentração de 400 $\mu \mathrm{g} / \mathrm{mL}$ em tampão cloreto de sódio $(\mathrm{NaCl}) 150 \mathrm{mM}$. Os dados foram obtidos em um espectrofotômetro de fluorescência F-4500 da marca Hitachi, a $25{ }^{\circ} \mathrm{C}$. O comprimento de onda de excitação do triptofano é de $295 \mathrm{~nm}$ e, portanto este foi o valor utilizado na análise das amostras. O intervalo de emissão espectral considerado foi entre 300 e $500 \mathrm{~nm}$. As leituras foram efetuadas contra um branco de tampão $\mathrm{NaCl} 150 \mathrm{mM}$.

\subsection{Dicroísmo Circular}

A técnica de Dicroísmo Circular (CD) permite avaliar mudanças ocorridas especificamente na estrutura secundária ( $\alpha$-hélice, folha $\beta$ e estrutura randômica) da molécula protéica.

\subsubsection{Princípio de análise por Dicroísmo Circular}

O método de Dicroísmo Circular leva em conta a estereoquímica da molécula (Crabee, 1972). Pode ser aplicado a qualquer composto opticamente ativo que tenha um cromóforo que, no caso dos peptídeos, é a ligação amida. Essa espectroscopia utiliza uma luz circularmente polarizada na ausência de um campo magnético e consiste na diferença de absorção entre a luz polarizada para 
a direita e para a esquerda no momento da interação desta com a molécula (Casare, 2009).

Em moléculas pequenas, detecta-se a assimetria do carbono quiral e a possível assimetria causada pela ligação a uma macromolécula ou agregado. No caso das macromoléculas, detecta-se a assimetria causada por suas conformações (Rodger \& Nordén, 1997).

No caso de proteínas e peptídeos, os cromóforos responsáveis pelo espectro de CD são: a ligação amídica, os resíduos aromáticos de triptofano, tirosina e fenilalanina, e as pontes dissulfeto.

Os resíduos aromáticos das proteínas, assim como as pontes dissulfeto, absorvem no ultravioleta (UV) próximo, que se estende de 250 a 300 $\mathrm{nm}$ (Strickland, 1974) e também contribuem para o espectro de CD da região do UV distante, de 200 a $10 \mathrm{~nm}$ aproximadamente (Casare, 2009).

No espectro de CD, a estrutura protéica de a-hélice é observada como uma banda negativa próxima a $222 \mathrm{~nm}$. Isto se deve a forte ligação de pontes de hidrogênio no meio conformacional. Esta transição é relativamente independente do comprimento da hélice. A segunda transição a $190 \mathrm{~nm}$ é dividida em uma banda negativa próxima a $208 \mathrm{~nm}$ e outra banda positiva próxima a $192 \mathrm{~nm}$. Ambas as bandas são de intensidade reduzidas em pequenas hélices. $O$ espectro de $C D$ de folha $\beta$ localiza-se em uma banda negativa próxima a $216 \mathrm{~nm}$, uma banda positiva entre 195 e 200 nm e uma banda negativa próxima a 175 nm. Entretanto, a posição e intensidade destas bandas são variáveis, resultando em uma menor precisão para predizer a estrutura de folha $\beta$ do que para de $\alpha$-hélice (Peltron \& McLean, 2000).

\subsubsection{Procedimento para análise de Dicroísmo Circular}

As amostras de crotamina e de crotoxina (forma nativa e irradiada) na concentração de $400 \mu \mathrm{g} / \mathrm{mL}$ em tampão fosfato $25 \mathrm{mM}, \mathrm{pH}$ 7,2, foram analisadas em um espectrômetro Jasco-810. Para esta análise $500 \mu \mathrm{L}$ das amostras foram colocadas em celas de quartzo, com $0,1 \mathrm{~mm}$ e uma variação de comprimento de onda de 185 a $260 \mathrm{~nm}$. No caso da crotoxina, a variação do comprimento de onda 
foi entre 190 e $250 \mathrm{~nm}$. A temperatura durante todo o experimento foi mantida em $20^{\circ} \mathrm{C}$.

\subsection{Calorimetria Diferencial}

A técnica de Calorimetria Diferencial (Differential Scanning Calorimetric - DSC) é de grande valia na caracterização de mudanças conformacionais em proteínas induzidas por temperatura, considerando principalmente os fatores envolvidos na estabilidade protéica (Sanchez-Ruiz, 1995).

\subsubsection{Princípio de análise por Calorimetria Diferencial}

Um calorímetro diferencial consiste basicamente de 2 células: a célula de referência e a da amostra. Ambas as células são aquecidas constante e simultaneamente. O sinal captado no sistema consiste na diferença da capacidade calorífera entre as duas células. Usualmente o perfil calorimétrico mostra um pico de transição que é atribuído à absorção de calor associada à desnaturação da proteína, enquanto que os valores de pré e pós-transição refletem a capacidade calorífera parcial dos estados nativo e desnaturado da proteína, respectivamente (Privalov e cols., 1974; Krishnan \& Brandts, 1978; Privalov, 1980).

Os resultados experimentais de DSC são dados muitas vezes como um excesso da capacidade calorífera $\left(C_{p}^{e x}\right)$ versus o perfil de temperatura. Por meio da integral da capacidade pela temperatura, o excesso de entalpia pode ser obtido:

$$
\langle\Delta H\rangle=\int_{T_{0}}^{T} C_{p}^{e x} d T
$$

Em que $\mathbf{T}_{0}$ é a menor temperatura que essencialmente todas as proteínas estão no estado nativo e os brackets são usados para indicar que $\langle\Delta H\rangle$ pode ser expresso em termos da média dos estados protéicos. 
O mais simples mecanismo de desnaturação protéica o qual envolve apenas os estados nativo (N) e desnaturado (D) da proteína são significantemente estimados e suas quantidades relativas em uma dada temperatura são determinadas pelo valor da constante de equilíbrio de desnaturação (K) naquela temperatura:

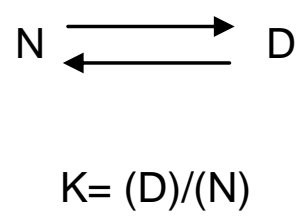

Mudanças desnaturacionais das quantidades termodinâmicas $\left(\Delta_{N}^{D} J\right)$ são definidas como a diferença entre o valor da quantidade termodinâmica para o estado desnaturado e aquele para o estado nativo: $\Delta_{N}^{D} J=J(D)-J(N)$, onde $J$ pode ser a energia de Gibbs $(\mathrm{G})$, entalpia $(\mathrm{H})$, entropia $(\mathrm{S})$, capacidade calorimétrica a pressão constante $\left(C_{p}\right)$ e outros (Sanchez-Ruiz, 1995).

Assim, a mudança na capacidade térmica $\left(\Delta_{N}^{D} C\right)$ para as transições energéticas ocorridas em uma molécula que tem a sua temperatura aumentada, pode ser avaliada por meio da diferença entre as linhas base do perfil calorimétrico, considerando as medidas de pré e pós-transição.

A princípio, as transições de entropia $\left(\Delta_{N}^{D} S\right)$ e mudanças da energia livre de Gibbs $\left(\Delta_{N}^{D} G\right)$ também podem ser extraídas dos dados obtidos em DSC, entretanto, devido à maior dificuldade de interpretação, a dependência em relação a outros fatores envolvidos, e a propagação de erros experimentais, tais dados são significantemente menos utilizados do que $\left(\Delta_{N}^{D} C\right)$ e $\left(\Delta_{N}^{D} H\right)$, que são valores obtidos diretamente (Plum \& Breslauer, 1995).

Portanto, deve-se enfatizar que os dados de DSC promovem um modelo para avaliação de mudanças na capacidade térmica e na entalpia de macromoléculas por meio de transições de ordem e desordem. 


\subsubsection{Procedimento para análise de Calorimetria Diferencial}

O perfil termométrico foi obtido a partir de um calorímetro METTLER TOLEDO, DSC $822^{\mathrm{e}}$. As amostras de crotamina e crotoxina, ambas em solução salina, no estado nativo e irradiado (400 $\mu \mathrm{g} / \mathrm{mL})$, foram submetidas a um aquecimento gradual ( $1^{\circ} \mathrm{C} /$ minuto), com a temperatura inicial de $20{ }^{\circ} \mathrm{C}$ e a final de $90 \stackrel{\circ}{ } \mathrm{C}$. O sinal foi registrado a cada 0,5 minuto.

\subsection{Espectroscopia de Infravermelho}

A espectroscopia de Infravermelho é uma técnica experimental bem estabelecida para a análise da estrutura secundária de polipeptídeos e proteínas em termos da vibração de unidades estruturais repetidas.

\subsubsection{Princípio de análise por Infravermelho}

O espectro infravermelho (IR) de uma amostra é produzido pela diferença da intensidade da radiação infravermelho antes e depois da sua passagem pela amostra em análise. A região infravermelho do espectro eletromagnético compreende do comprimento de onda da luz visível até a região de microondas ou até a região de pequenas ondas de radar (Figura 12). A radiação IR origina-se na emissão térmica de uma fonte de calor. Por convenção, na região IR fala-se em "número de onda", por exemplo, o número de ondas por

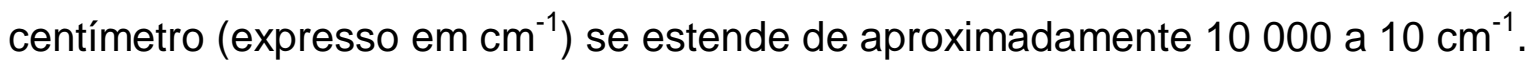




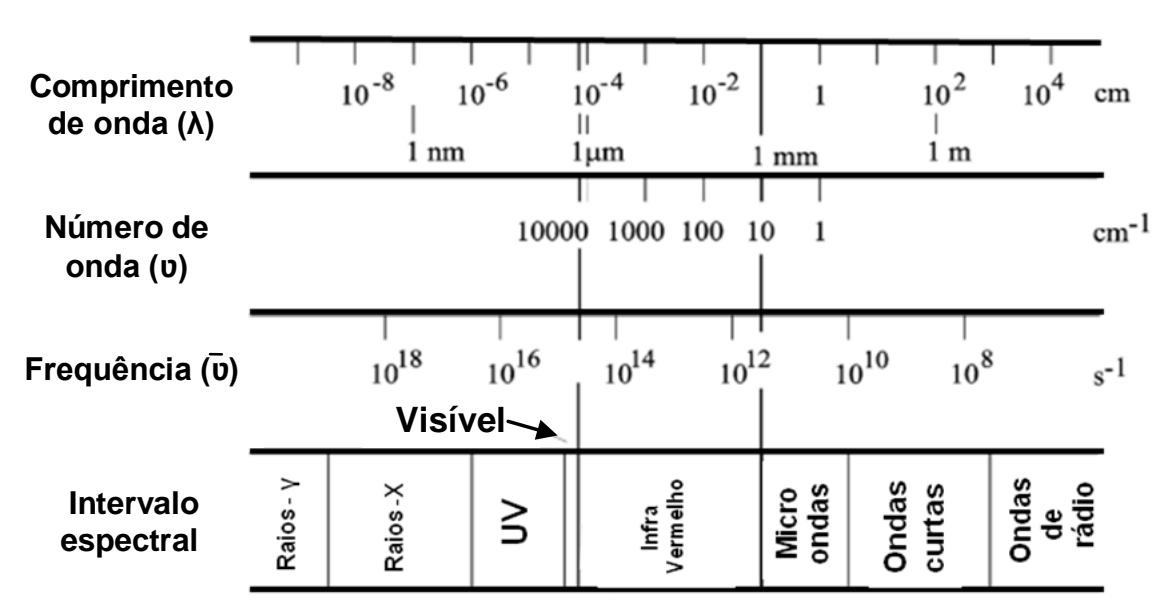

Figura 12: O espectro eletromagnético (Naumann, 2000; modificado).

O espectro IR da maioria dos materiais mostra um grande número de bandas de absorção. Estas bandas são originárias da interação (troca de energia) entre discretos quanta de luz e os movimentos mecânicos (modos vibracionais e rotacionais) das moléculas excitadas pela absorção da radiação IR (Beekes e cols., 2007). Uma vez que os constituintes das amostras biológicas estão normalmente presentes na fase condensada (sólidos, líquidos ou soluções), apenas os modos vibracionais são observados com a espectroscopia IR para o material em análise (Naumann, 2000).

Inovações tecnológicas permitiram o desenvolvimento do método denominado Transformada de Fourier (Fourier transform - FT) para a aquisição de dados em espectroscopia IR. O instrumento FT-IR é não dispersivo e faz uso de um interferômetro para aquisição dos dados e do intervalo espectral de forma simultânea. Este método não mede diretamente o espectro desejado, uma vez que os padrões de interferência dos sinais modulados de interferogramas são amplificados, digitalizados, eletronicamente armazenados e finalmente transformados em um espectro por meio de um algoritmo. Assim, a transformada de Fourier pode ser considerada como uma simples manipulação matemática de frequências individuais extraídas do interferograma para a representação final do espectro de IR.

Outra técnica associada ao sistema de FTIR é a Reflectância Total Atenuada (Attenuated Total Reflectance - ATR). O acessório de ATR opera medindo as mudanças que ocorrem no feixe infravermelho quando este incide na 
amostra e ao atravessá-la, é internamente refletido. A Figura 13 ilustra o princípio da técnica.

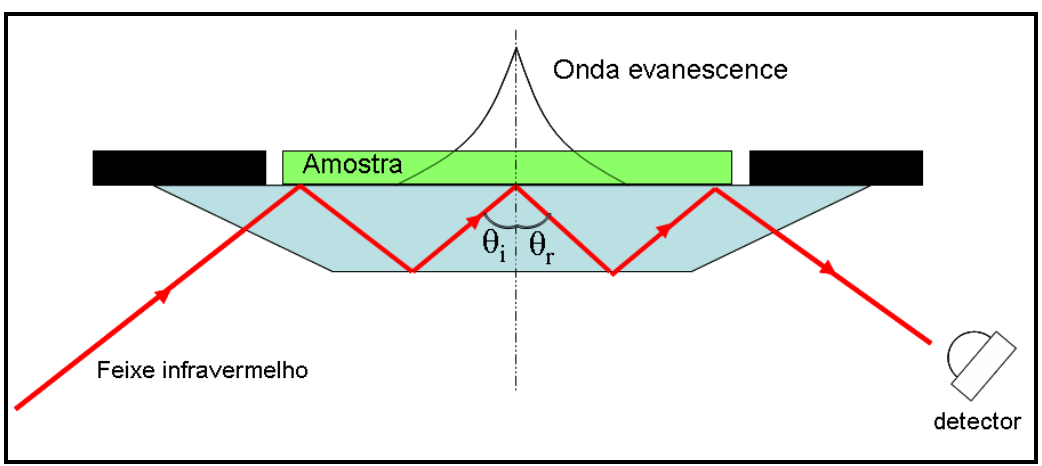

Figura 13: Sistema ilustrativo do princípio da técnica de ATR.

O feixe infravermelho sofre sucessivas reflexões no interior do cristal.

O feixe infravermelho é direcionado a um cristal opticamente denso, com um alto índice de refração. A reflectância interna cria uma onda evanescente que ultrapassa o limite do cristal e entra em contato com a amostra. Na região do espectro IR onde a amostra absorve energia, a onda evanescente será atenuada ou alterada. A energia atenuada de cada onda evanescente volta ao feixe IR, do lado oposto à incidência inicial do feixe e é então captada pelo detector. Assim, o sistema gera o espectro IR (PerkinElmer $\left.{ }^{6}\right)$.

\subsubsection{Procedimento para análise de Infravermelho}

As amostras de crotamina e crotoxina, na forma nativa e irradiada, foram analisadas usando um aparato de ATR-FTIR (Thermo-Nicolet FTIR Spectrofotometer Model 6700 CA, USA - FAPESP/CEPOP, 05/516892).

Durante as medidas foram empregadas as seguintes configurações no espectrômetro: 120 scans, resolução de $4 \mathrm{~cm}^{-1}$, velocidade de $0,69 \mathrm{~cm} / \mathrm{s}$, região espectral analisada entre $650-4000 \mathrm{~cm}^{-1}$, tendo em vista que nesta região são esperadas as maiores modificações espectroscópicas decorrentes das alterações biológicas. Os espectros obtidos foram corrigidos na linha base e normalizados em relação à área da banda da amida I para minimizar a variação da homogeneidade das amostras. Os espectros foram convertidos em segunda 
derivada para melhor análise dos picos e deslocamentos após o procedimento experimental (Naumann, 2001).

Para análise estatística das diferenças espectrais entre a proteína nativa e irradiada, adotou-se 9 picos que expressam a vibração da estrutura secundária da crotamina e da crotoxina, sendo em $1621 \mathrm{~cm}^{-1}$ e $1633 \mathrm{~cm}^{-1}$ as regiões correspondentes à vibração da folha $\beta$; em $1644 \mathrm{~cm}^{-1}$ e $1650 \mathrm{~cm}^{-1}$ as correspondentes à estrutura randômica; em $1657 \mathrm{~cm}^{-1}$ à $\alpha$-hélice, e por último, as vibrações em $1667 \mathrm{~cm}^{-1}, 1674 \mathrm{~cm}^{-1}, 1678 \mathrm{~cm}^{-1}$ e $1688 \mathrm{~cm}^{-1}$ correspondentes à $\beta$ turns (Cui e cols., 2001). Deste modo, calculou-se a área destas regiões espectrais com ajuste da linha base e normalização pela banda de 1590 - 1700 $\mathrm{cm}^{-1}$ (amida I), fazendo-se os histogramas correspondentes à crotamina e à crotoxina que expressam, em porcentagem, a variação das estruturas secundárias nas duas toxinas. 


\section{RESULTADOS}

A seguir serão apresentados os resultados referentes ao fracionamento do veneno total da C.d.terrificus para obtenção das proteínas de interesse crotamina e crotoxina - bem como a análise estrutural dessas toxinas, nos estados nativo e irradiado, por Fluorescência, Dicroísmo Circular, Calorimetria Diferencial e Espectroscopia de Infravermelho.

\subsection{Isolamento da crotoxina e da crotamina}

Na Figura 14 está apresentado o perfil cromatográfico da primeira etapa de fracionamento (exclusão molecular) do veneno total da C.d.terrificus. $\mathrm{O}$ pico 1 representa a fração correspondente à convulxina, o pico 2 a correspondente à delta-toxina, o pico 3 é a fração da giroxina, o pico 4 a da crotoxina e o pico 5 a fração da crotamina. Estes dois últimos picos são os de interesse neste trabalho.

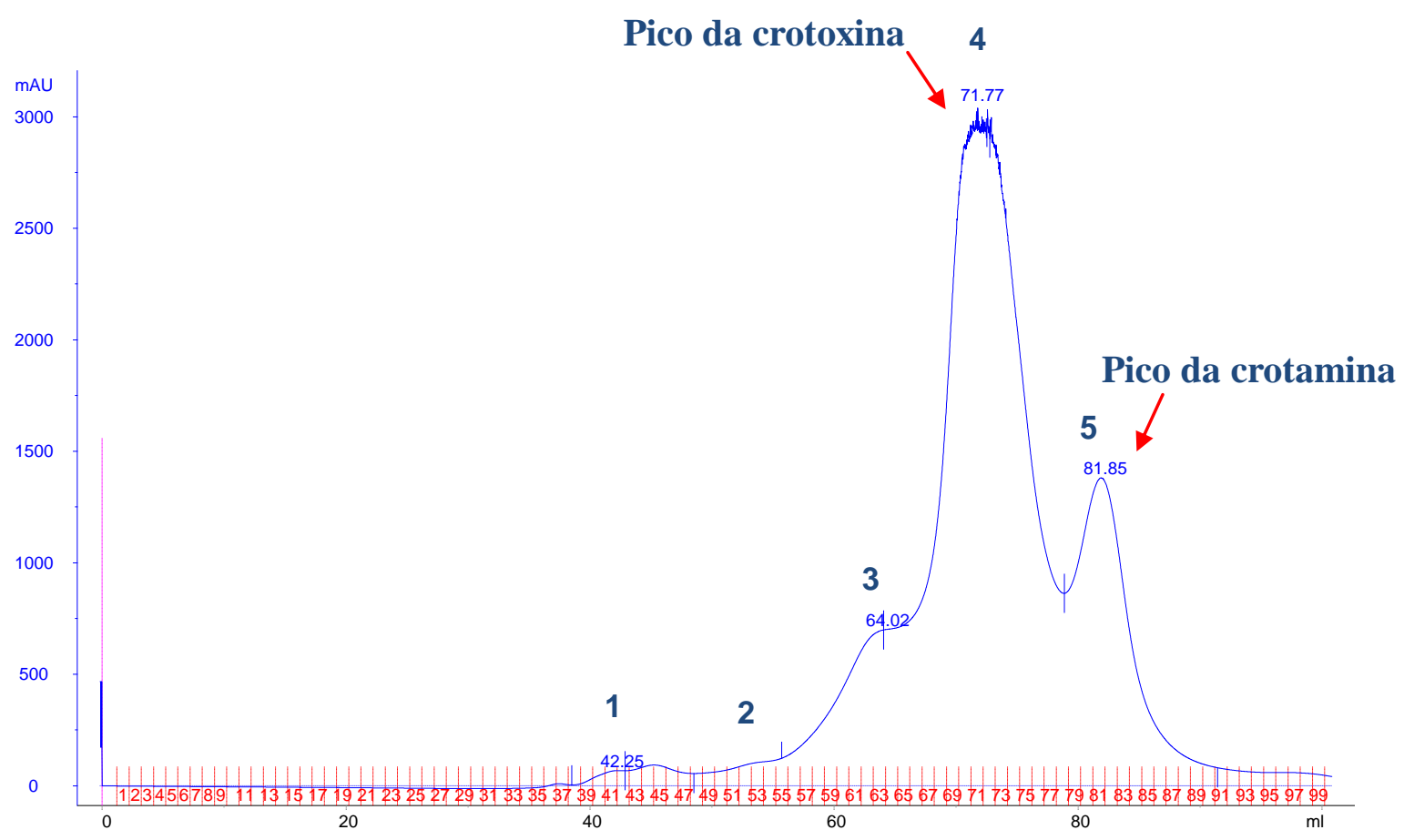

Figura 14: Cromatograma do veneno total da C.d.terrificus em coluna de exclusão molecular Superdex G-75. O tampão utilizado para a eluição dos picos foi o formiato de amônio, 100 mM, pH 3,0. Os picos indicados correspondem à convulxina (pico 1), deltatoxina (pico 2), giroxina (pico 3), crotoxina (pico 4) e crotamina (pico 5). 
A Tabela 2 resume os dados obtidos na cromatografia correspondente à Figura 14. Pode-se observar, para cada pico, o volume de retenção $(\mathrm{mL})$, a área total do pico $\left(\mathrm{mAU}^{*} \mathrm{~mL}\right)$, a porcentagem da relação área/área do pico e a altura do pico (mAU).

Tabela 2: Dados referentes à cromatografia do veneno total da C.d.terrificus.

\begin{tabular}{ccccc}
\hline $\begin{array}{c}\text { Número } \\
\text { (pico) }\end{array}$ & $\begin{array}{c}\text { Volume de } \\
\text { retenção }(\mathbf{m L})\end{array}$ & $\begin{array}{c}\text { Área } \\
(\mathbf{m A U} \mathbf{m L})\end{array}$ & $\begin{array}{c}\text { Área/Área do pico } \\
(\text { volume - \%) }\end{array}$ & Altura (mAU) \\
\hline 1 & 42,25 & 184,72 & 0,51 & 68,55 \\
\hline 2 & 45,20 & 426,20 & 1,18 & 93,77 \\
\hline 3 & 66,38 & $4.932,23$ & 13,61 & 752,72 \\
\hline 4 & 71,77 & $23.048,92$ & 63,58 & $3.052,47$ \\
\hline 5 & 81,85 & $7.659,81$ & 21,13 & $1.381,46$ \\
\hline
\end{tabular}

A Figura 15 representa a recromatografia da crotoxina (pico 4 da Figura 14), em coluna de troca aniônica - Mono Q. Para a eluição da fração de interesse foi utilizado um gradiente linear de $\mathrm{NaCl}$ de 0 a $1 \mathrm{M}$.

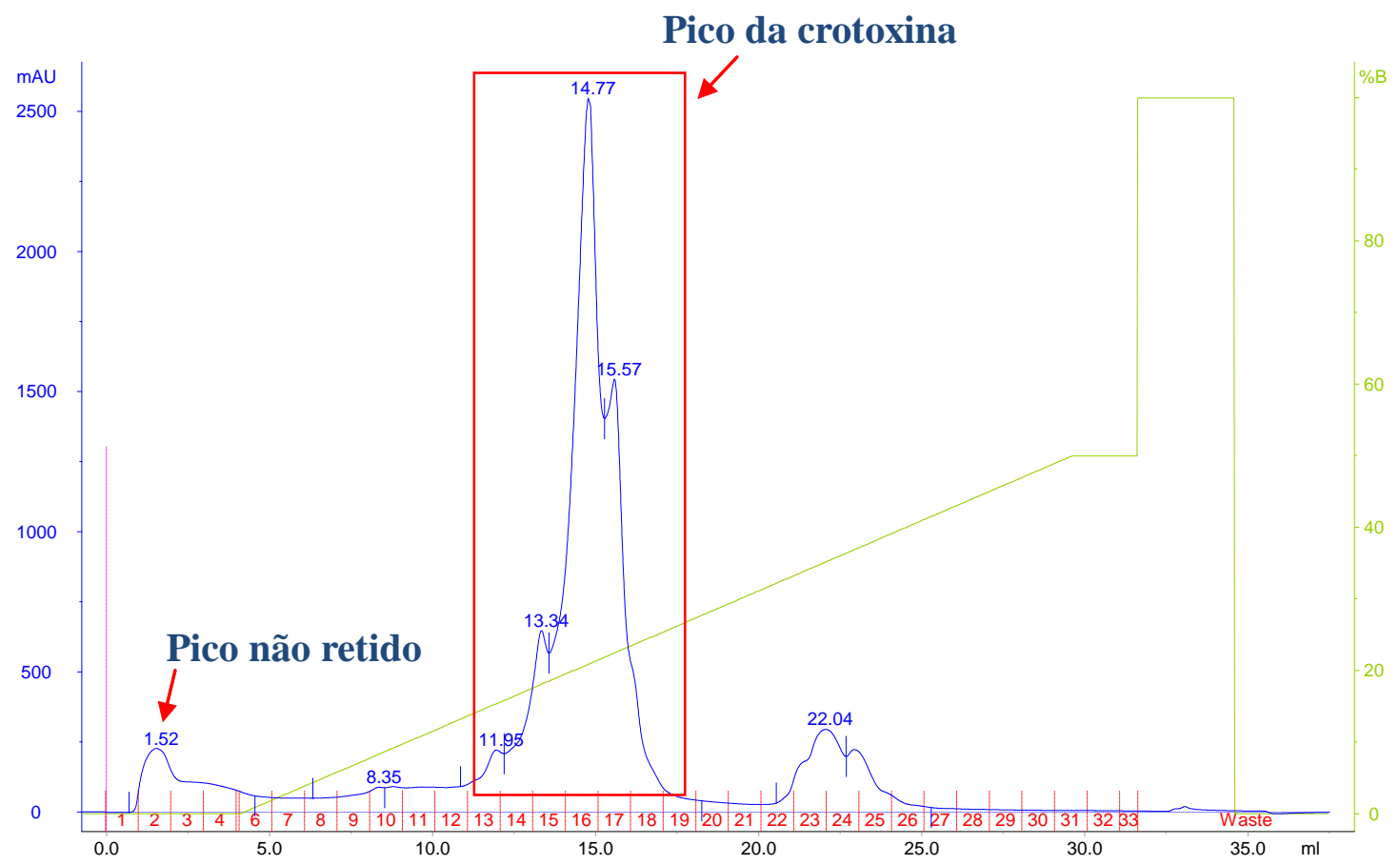

Figura 15: Recromatografia da crotoxina em coluna de troca aniônica (Mono Q). Utilizouse tampão Tris/ $\mathrm{HCl}, 50 \mathrm{mM}, \mathrm{pH} 8,2$. O gradiente linear de $\mathrm{NaCl}$ variou de 0 a $1 \mathrm{M}$. $\mathrm{O}$ pool de crotoxina coletado está compreendido no diagrama. 
Na Tabela 3 são mostrados os dados obtidos na segunda etapa cromatográfica correspondente à Figura 15. Os picos identificados pelos números $3,4,5$ e 6 representam a fração da crotoxina. O pico 1 é a fração não retida na coluna.

Tabela 3: Dados referentes à recromatografia (troca aniônica) da crotoxina.

\begin{tabular}{ccccc}
\hline $\begin{array}{c}\text { Número } \\
\text { (pico) }\end{array}$ & $\begin{array}{c}\text { Volume de } \\
\text { retenção }(\mathbf{m L})\end{array}$ & $\begin{array}{c}\text { Área } \\
(\mathbf{m A U} \mathbf{m L})\end{array}$ & $\begin{array}{c}\text { Área/Área do pico } \\
(\text { volume - \%) }\end{array}$ & Altura (mAU) \\
\hline 1 & 1,52 & 443,29 & 7,75 & 227,82 \\
\hline 2 & 11,95 & 242,31 & 4,24 & 222,06 \\
\hline 3 & 13,34 & 535,83 & 9,37 & 647,85 \\
\hline 4 & 14,77 & $2.474,17$ & 43,28 & $2.547,80$ \\
\hline 5 & 15,57 & $1.308,81$ & 22,89 & $1.545,10$ \\
\hline 6 & 22,04 & 415,25 & 7,26 & 295,73 \\
\hline 7 & 22,92 & 297,50 & 5,20 & 223,72 \\
\hline
\end{tabular}

A Figura 16 ilustra o segundo passo cromatográfico da crotamina (pico 5 da Figura 14), em coluna de troca catiônica do tipo Resource S. O gradiente linear de $\mathrm{NaCl}$ utilizado para eluição da fração de interesse variou de 0 a $2 \mathrm{M}$.

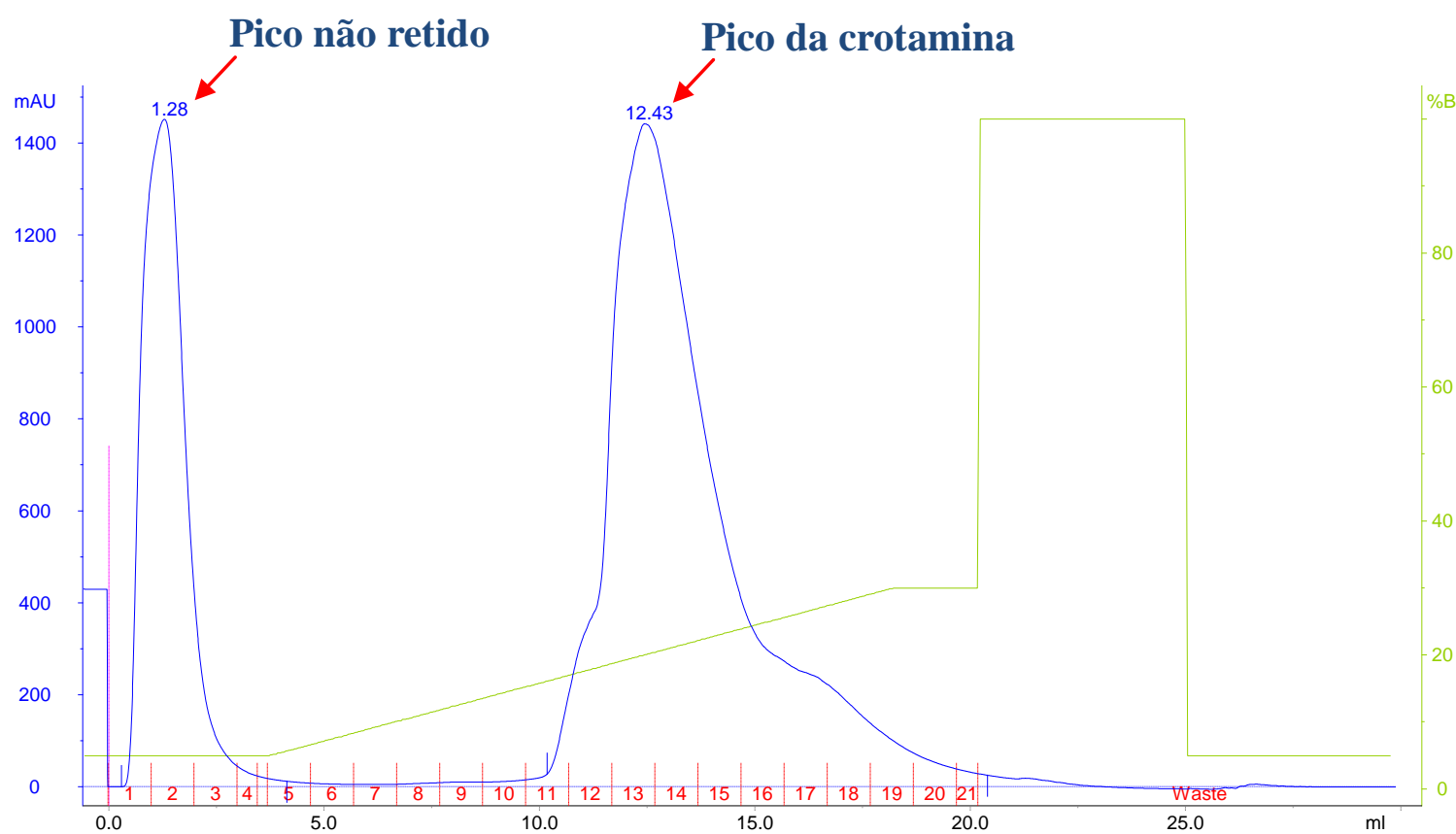

Figura 16: Recromatografia da crotamina em coluna de troca catiônica (Resource S). Utilizou-se tampão fosfato de sódio, $50 \mathrm{mM}, \mathrm{pH} 7,8$. O gradiente linear de $\mathrm{NaCl}$ variou de 0 a $2 \mathrm{M}$. 
$\mathrm{Na}$ Tabela 4 são abordados os dados obtidos na segunda etapa cromatográfica da crotamina, correspondente à Figura 16.

Tabela 4: Dados referentes à recromatografia (troca catiônica) da crotamina.

\begin{tabular}{ccccc}
\hline $\begin{array}{c}\text { Número } \\
\text { (pico) }\end{array}$ & $\begin{array}{c}\text { Volume de } \\
\text { retenção }(\mathbf{m L})\end{array}$ & $\begin{array}{c}\text { Área } \\
\left(\mathbf{m A U}^{\star} \mathbf{m L}\right)\end{array}$ & $\begin{array}{c}\text { Area/Área do pico } \\
\text { (volume - \%) }\end{array}$ & Altura (mAU) \\
\hline 1 & 1,28 & $1.729,6$ & 27,84 & $1.452,22$ \\
\hline 2 & 12,43 & $4.482,6$ & 72,16 & $1.442,29$ \\
\hline
\end{tabular}

Após cada etapa cromatográfica, foi realizada uma análise analítica em coluna de gel filtração (Superdex 75) com o objetivo de avaliar o grau de pureza das amostras de interesse.

A Figura 17 refere-se à gel filtração analítica da fração correspondente à crotoxina após a primeira etapa de purificação.

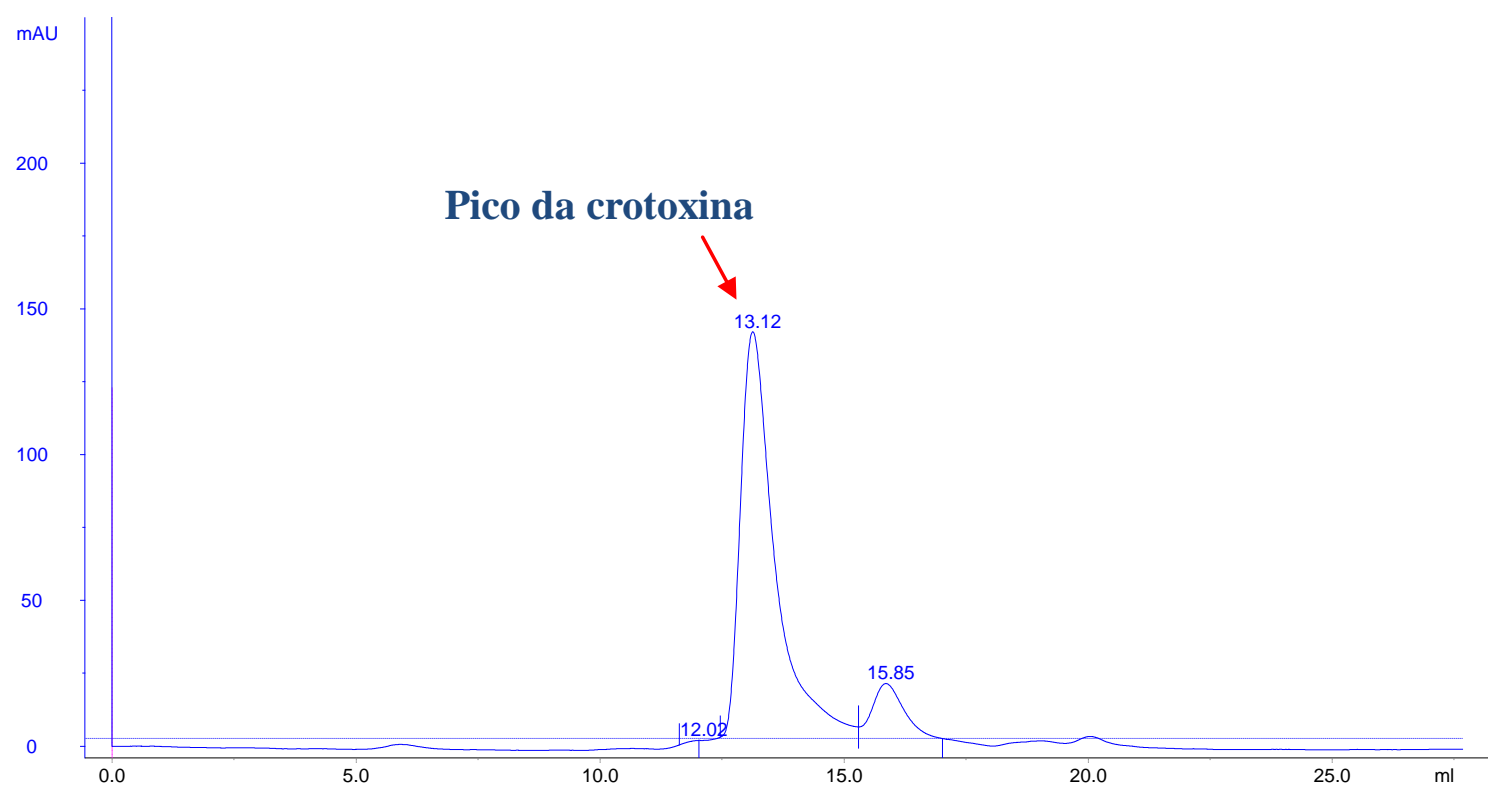

Figura 17: Gel filtração analítica da fração correspondente à crotoxina após a primeira etapa de fracionamento (Figura 14). A coluna Superdex 75 (24 mL) foi ambientada em tampão formiato, $100 \mathrm{mM}, \mathrm{pH} 3,0$.

$\mathrm{Na}$ Tabela 5 pode-se observar os dados obtidos na gel filtração analítica do pico da crotoxina mostrado na Figura 17. 
Tabela 5: Dados referentes à gel filtração analítica da crotoxina após a primeira etapa de fracionamento.

\begin{tabular}{ccccc}
\hline $\begin{array}{c}\text { Número } \\
\text { (pico) }\end{array}$ & $\begin{array}{c}\text { Volume de } \\
\text { retenção }(\mathrm{mL})\end{array}$ & $\begin{array}{c}\text { Área } \\
\left(\mathbf{m A U} \mathbf{U L}^{*}\right)\end{array}$ & $\begin{array}{c}\text { Área/Área do pico } \\
(\text { volume - \%) }\end{array}$ & Altura (mAU) \\
\hline 1 & 12,02 & 0,75 & 0,51 & 2,05 \\
\hline 2 & 13,12 & 123,80 & 85,53 & 142,28 \\
\hline 3 & 15,85 & 20,21 & 13,96 & 21,56 \\
\hline
\end{tabular}

No cromatograma da Figura 17, o pico 2 corresponde à crotoxina. Na Tabela 5 é possível verificar que este pico representa aproximadamente $85 \%$ da área total do cromatograma, assim, pode-se dizer que o grau de pureza da crotoxina foi cerca de $85 \%$. Os outros dois picos observados no cromatograma representam, possivelmente, a giroxina (pico 1) e a crotamina (pico 3), principais contaminantes da crotoxina.

A Figura 18 refere-se à gel filtração analítica da fração correspondente à crotamina após a primeira etapa de fracionamento.

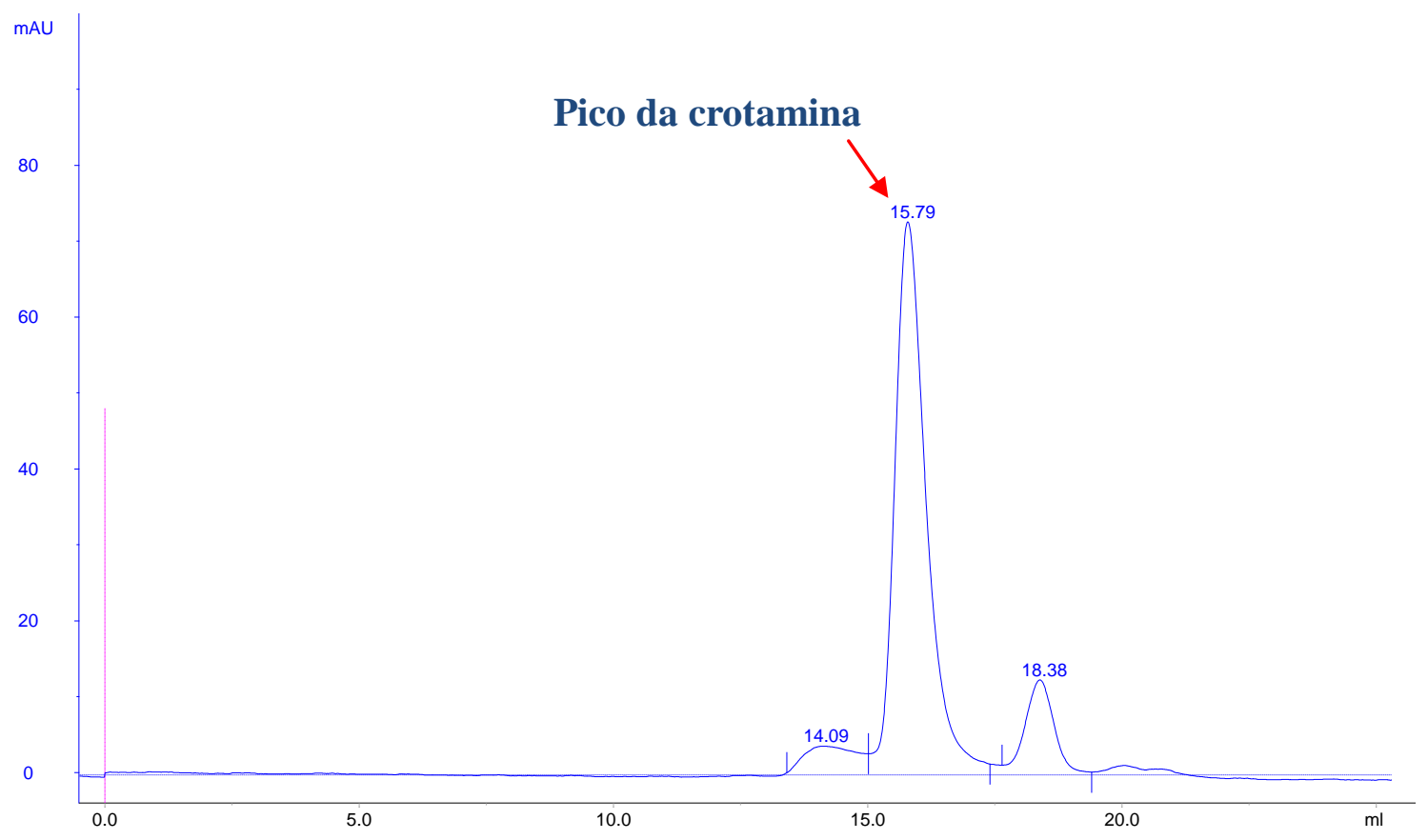

Figura 18: Gel filtração analítica da fração correspondente à crotamina após a primeira etapa de fracionamento (Figura 14). A coluna Superdex $75(24 \mathrm{~mL})$ foi ambientada em tampão formiato, 100 mM, pH 3,0.

$\mathrm{Na}$ Tabela 6 pode-se observar os dados obtidos na gel filtração analítica do pico da crotamina mostrado na Figura 18. 
Tabela 6: Dados referentes à gel filtração analítica da crotamina após primeira etapa de fracionamento.

\begin{tabular}{ccccc}
\hline $\begin{array}{c}\text { Número } \\
\text { (pico) }\end{array}$ & $\begin{array}{c}\text { Volume de } \\
\text { retenção }(\mathrm{mL})\end{array}$ & $\begin{array}{c}\text { Área } \\
\left(\mathrm{mAU} \mathbf{U}^{*} \mathrm{~mL}\right)\end{array}$ & $\begin{array}{c}\text { Área/Área do pico } \\
(\text { volume }-\%)\end{array}$ & Altura (mAU) \\
\hline 1 & 14,09 & 4,24 & 6,58 & 3,50 \\
\hline 2 & 15,79 & 52,31 & 81,21 & 72,58 \\
\hline 3 & 18,38 & 7,86 & 12,21 & 12,23 \\
\hline
\end{tabular}

No cromatograma representado pela Figura 18, pode-se verificar que 0 pico 2 refere-se à crotamina e corresponde à cerca de $81 \%$ da área total dos picos (Tabela 6). O pico 1 corresponde, possivelmente, à crotoxina e o pico 3 ao analgésico presente no veneno total da C.d.terrificus, que por sua vez, representam os principais contaminantes da crotamina.

Na Figura 19 é ilustrada a gel filtração analítica da crotoxina após a segunda etapa de isolamento.

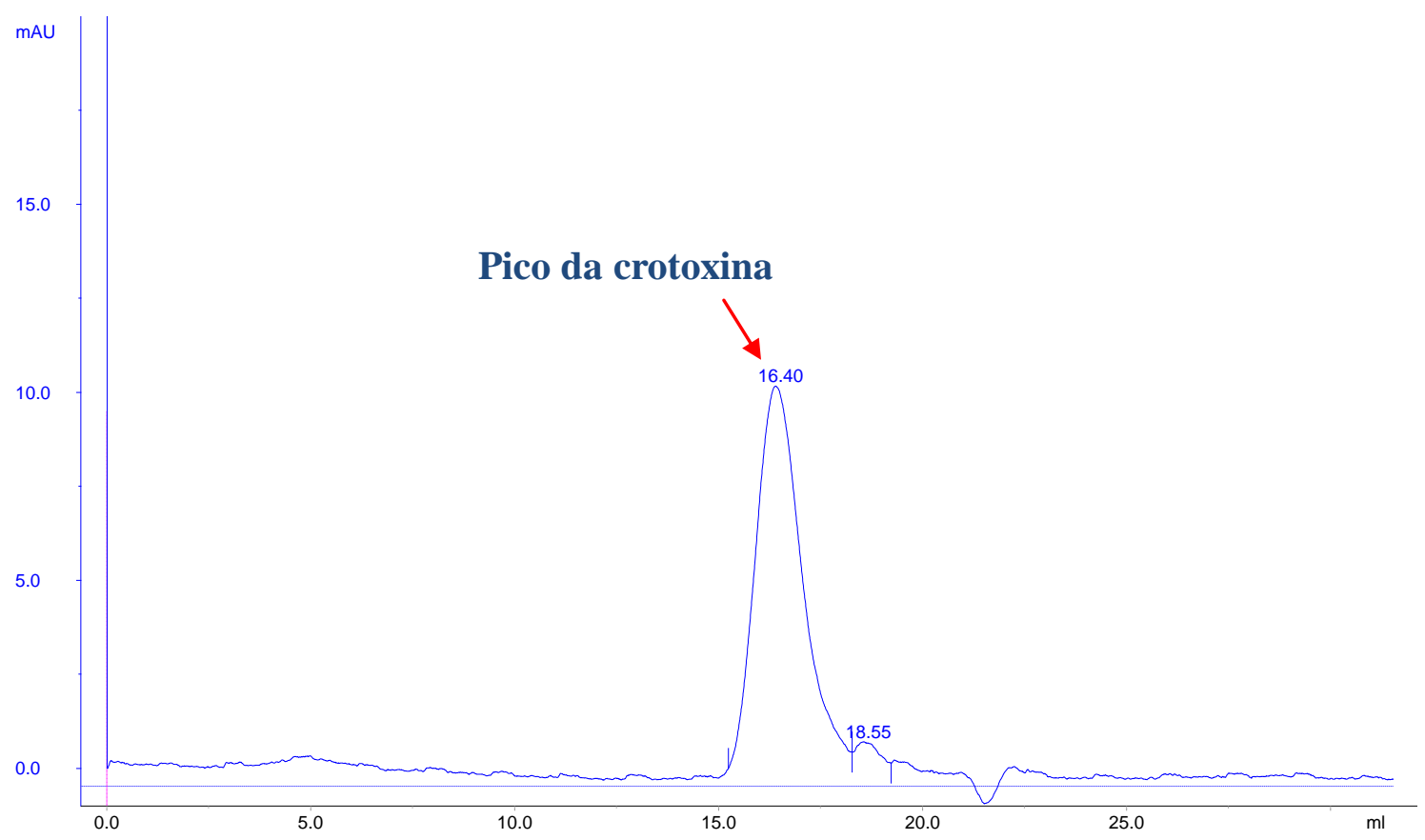

Figura 19: Gel filtração analítica da fração correspondente à crotoxina após a segunda etapa de isolamento (Figura 15). A coluna Superdex $75(24 \mathrm{~mL})$ foi ambientada em tampão formiato, 100 mM, pH 3,0.

Na Tabela 7 são mostrados os dados obtidos na gel filtração analítica após a segunda etapa de isolamento da crotoxina. 
Tabela 7: Dados referentes à gel filtração analítica da crotoxina após segunda etapa de fracionamento.

\begin{tabular}{ccccc}
\hline $\begin{array}{c}\text { Número } \\
\text { (pico) }\end{array}$ & $\begin{array}{c}\text { Volume de } \\
\text { retenção }(\mathbf{m L})\end{array}$ & $\begin{array}{c}\text { Área } \\
\left(\mathbf{m A U}^{*} \mathbf{m L}\right)\end{array}$ & $\begin{array}{c}\text { Área/Área do pico } \\
\text { (volume - \%) }\end{array}$ & Altura (mAU) \\
\hline 1 & 16,40 & 13,30 & 96,60 & 10,17 \\
\hline 2 & 18,55 & 0,47 & 3,40 & 0,72 \\
\hline
\end{tabular}

A partir da Tabela 7 é possível verificar que o pico referente à crotoxina apresentou grau de pureza de 96,6\%.

Na Figura 20 é representado o cromatograma da gel filtração analítica da crotamina após a segunda etapa de isolamento.

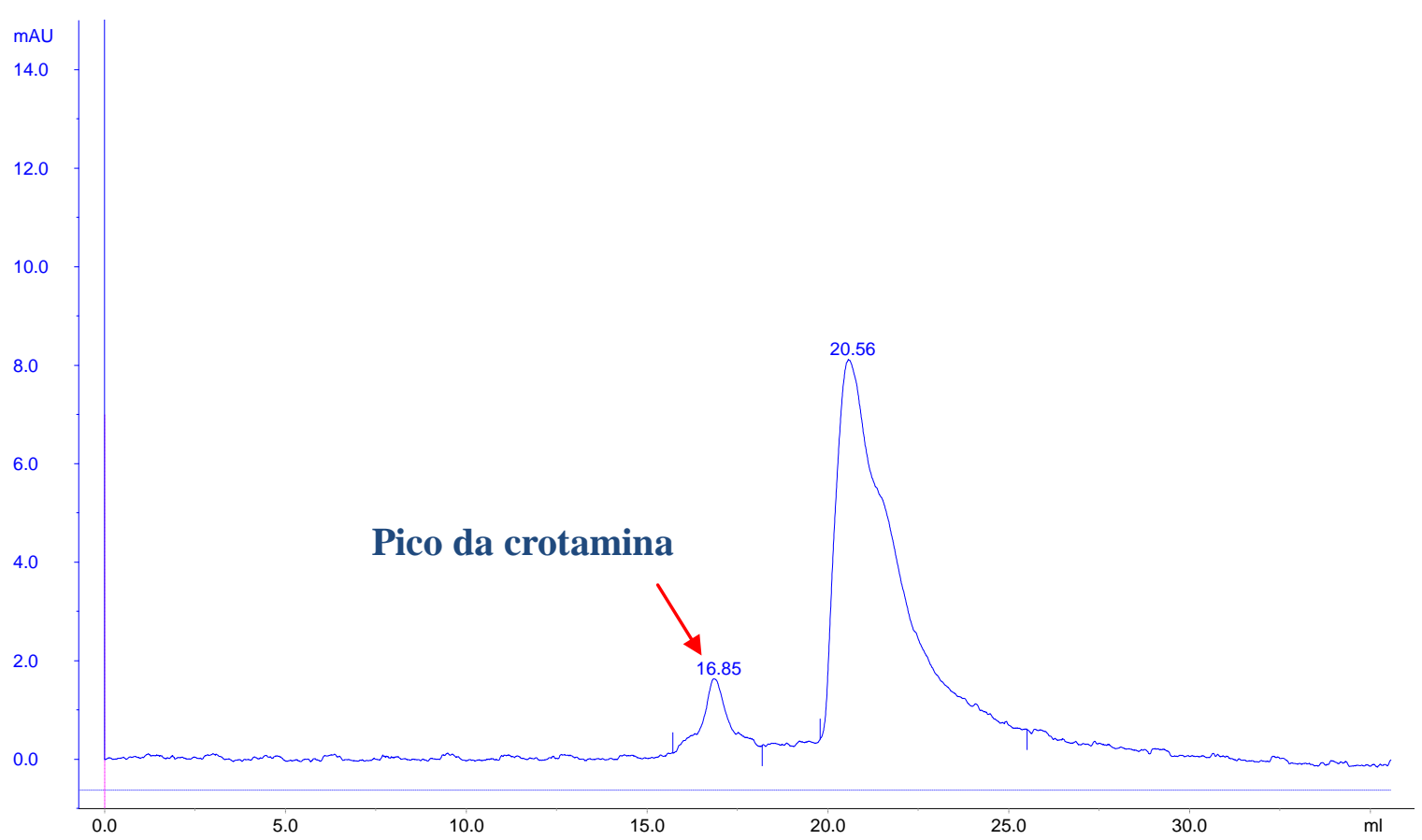

Figura 20: Gel filtração analítica da fração correspondente à crotamina após a segunda etapa de isolamento (Figura 16). A coluna Superdex $75(24 \mathrm{~mL})$ foi ambientada em tampão formiato, $100 \mathrm{mM}, \mathrm{pH} 3,0$.

A Tabela 8 resume os dados cromatográficos referentes à Figura 20. 0 pico correspondente à crotamina é de pouca relevância em relação ao pico posterior, considerando a área total do cromatograma. Uma hipótese para 0 observado é a perda da proteína de interesse no processo de diálise, sendo que o segundo pico pode representar componentes de menor massa molecular, entendidos como uma possível contaminação. 
Tabela 8: Dados referentes à gel filtração analítica da crotamina após segunda etapa cromatográfica.

\begin{tabular}{ccccc}
\hline $\begin{array}{c}\text { Número } \\
\text { (pico) }\end{array}$ & $\begin{array}{c}\text { Volume de } \\
\text { retenção }(\mathrm{mL})\end{array}$ & $\begin{array}{c}\text { Área } \\
\left(\mathrm{mAU} \mathbf{A L}^{\star} \mathrm{mL}\right)\end{array}$ & $\begin{array}{c}\text { Área/Área do pico } \\
(\text { volume }-\%)\end{array}$ & Altura (mAU) \\
\hline 1 & 16,85 & 1,14 & 6,73 & 1,64 \\
\hline 2 & 20,56 & 15,79 & 93,27 & 8,12 \\
\hline
\end{tabular}

Em substituição ao processo de diálise, que se mostrou pouco eficiente no caso da crotamina, foi realizada uma exclusão molecular (desalting) em coluna Sephadex G-10. O perfil cromatográfico obtido está ilustrado na Figura 21.

Pico do sal

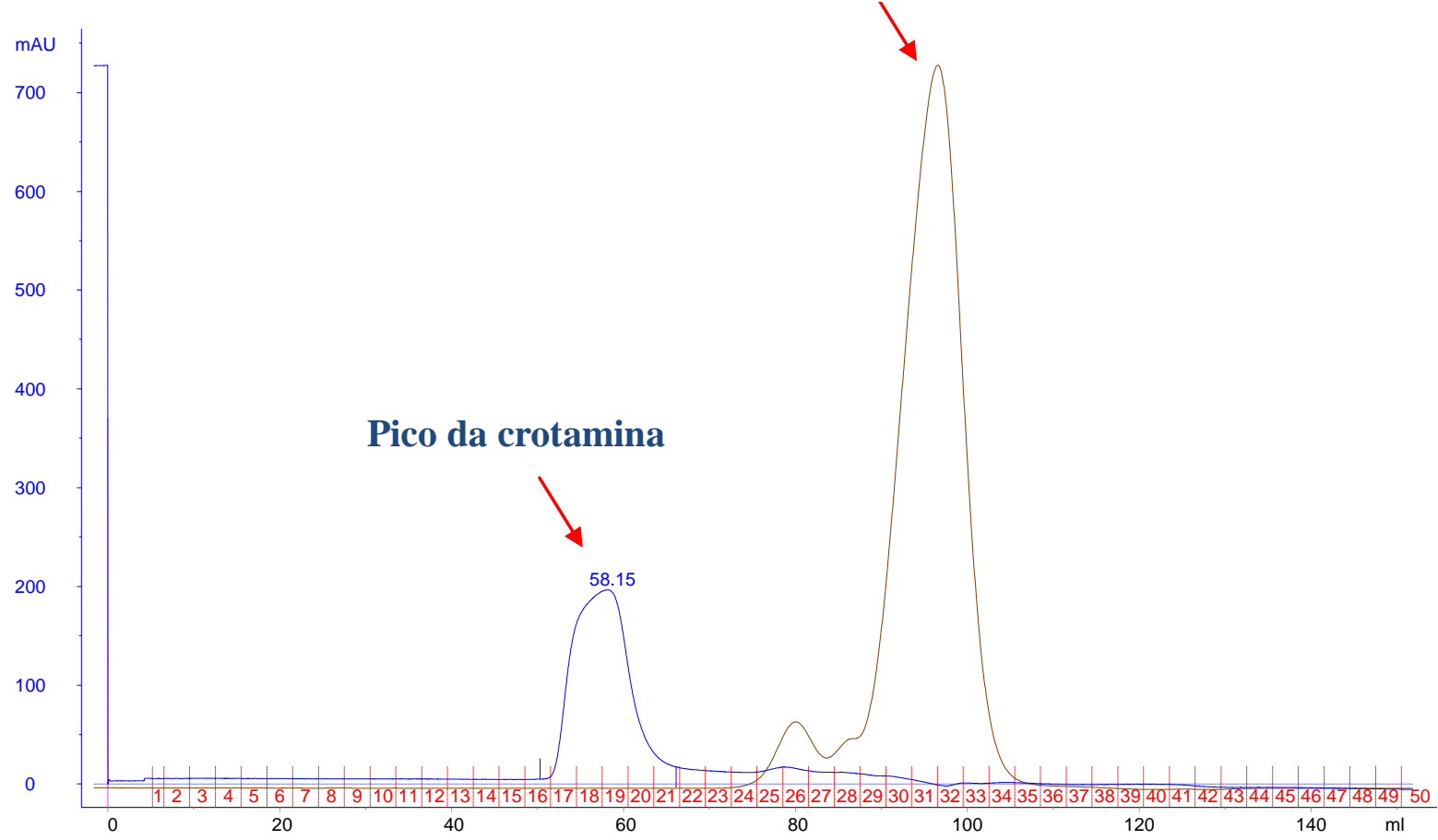

Figura 21: Perfil cromatográfico obtido na desalting (Sephadex G-10) da crotamina após troca iônica. O tampão utilizado foi o formiato de amônio, 100 mM, pH 3,0. Estão indicados o pico da crotamina e o pico da condutividade que representa a eluição do sal presente na amostra.

O pico ilustrado pelo perfil marrom na Figura 21 representa a medida da condutividade, o que, por sua vez, indica que a separação entre o sal e a amostra ocorreu de forma satisfatória.

$\mathrm{Na}$ Figura 16 observou-se que o pico correspondente à crotamina apresentou um shoulder (ombro) no lado direito. Na tentativa de explicar essa 
assimetria no pico de interesse, foi realizada uma cromatografia de fase reversa (RP-HPLC) representada pela Figura 22.

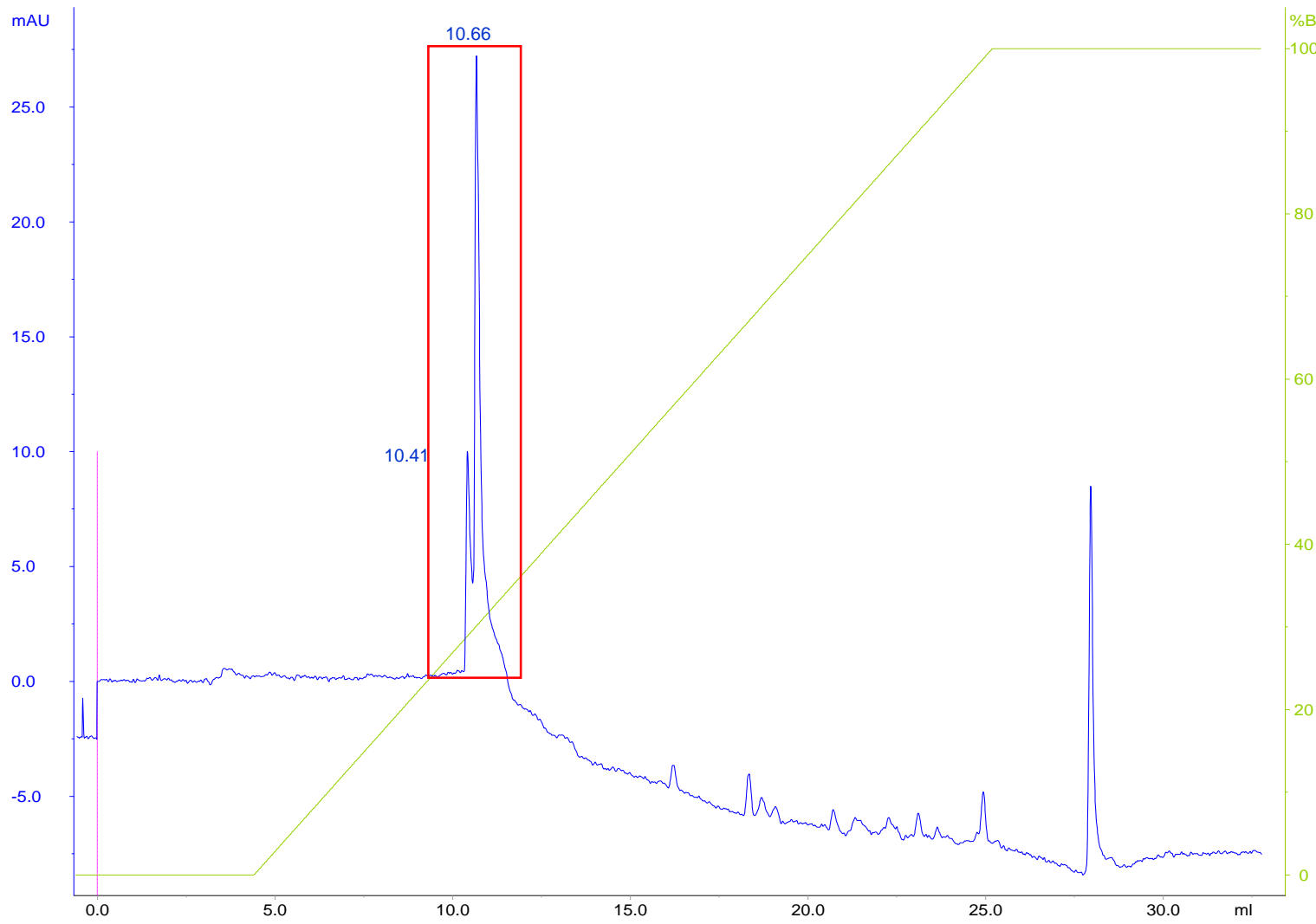

Figura 22: Cromatografia de fase reversa (coluna C8) da crotamina. Utilizou-se 0,05\% de ácido fórmico e um gradiente de acetonitrila (grau HPLC) para eluição da amostra.

Os dois picos destacados na Figura 22 foram eluídos com aproximadamente $30 \%$ de acetonitrila. Pode-se verificar que o pico 1 possui maior polaridade (menor hidrofobicidade) em relação ao pico 2, ambos compreendidos no diagrama. 


\subsection{Fluorescência}

Na Figura 23 estão apresentados os resultados obtidos na análise de fluorescência da crotoxina nativa e irradiada. O pico de emissão do triptofano foi aproximadamente a $340 \mathrm{~nm}$ sendo que o perfil da amostra irradiada se mostrou deslocado para a direita. A relação entre as intensidades não foi relevante.

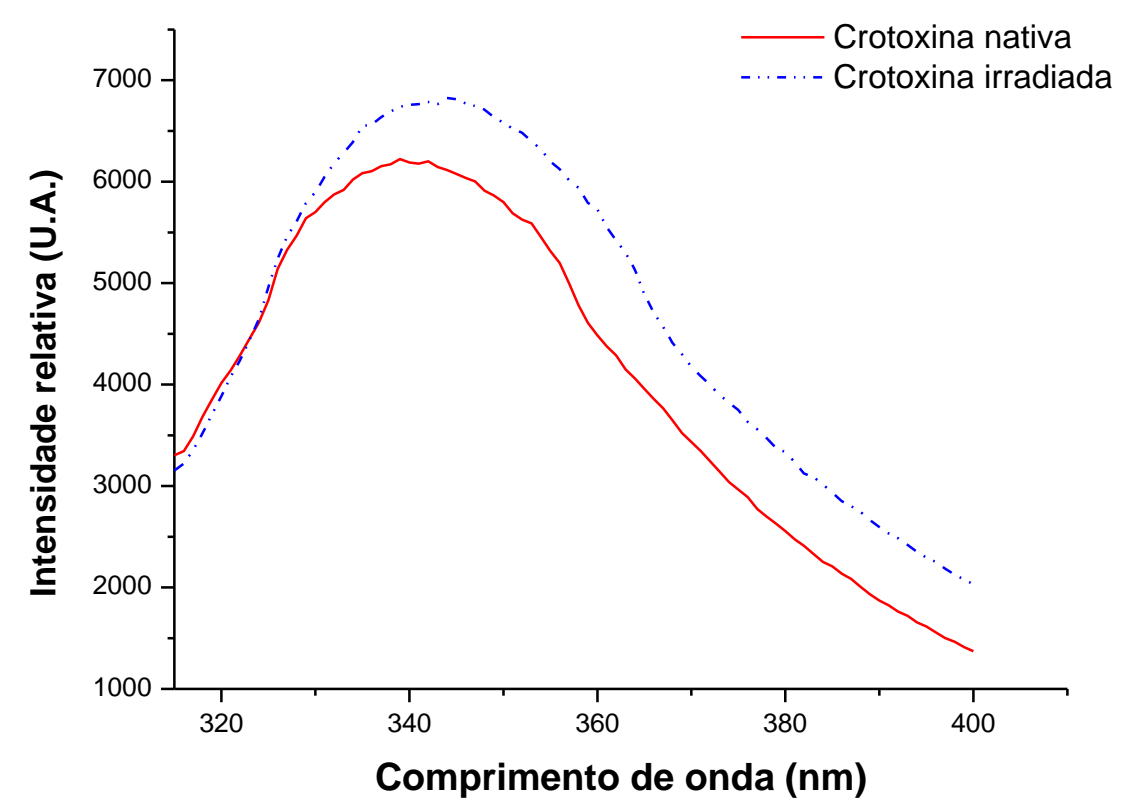

Figura 23: Análise de fluorescência da crotoxina nativa e irradiada, ambas na concentração de $400 \mu \mathrm{g} / \mathrm{mL}$ em tampão $\mathrm{NaCl} 150$ mM. 
$\mathrm{Na}$ Figura 24 estão apresentados os resultados da análise de fluorescência da crotamina nativa e irradiada. Pode-se observar para a proteína irradiada que o pico na região do triptofano $(350 \mathrm{~nm})$ possui intensidade aproximadamente 5 vezes menor do que a intensidade do pico relativo à proteína no estado nativo.

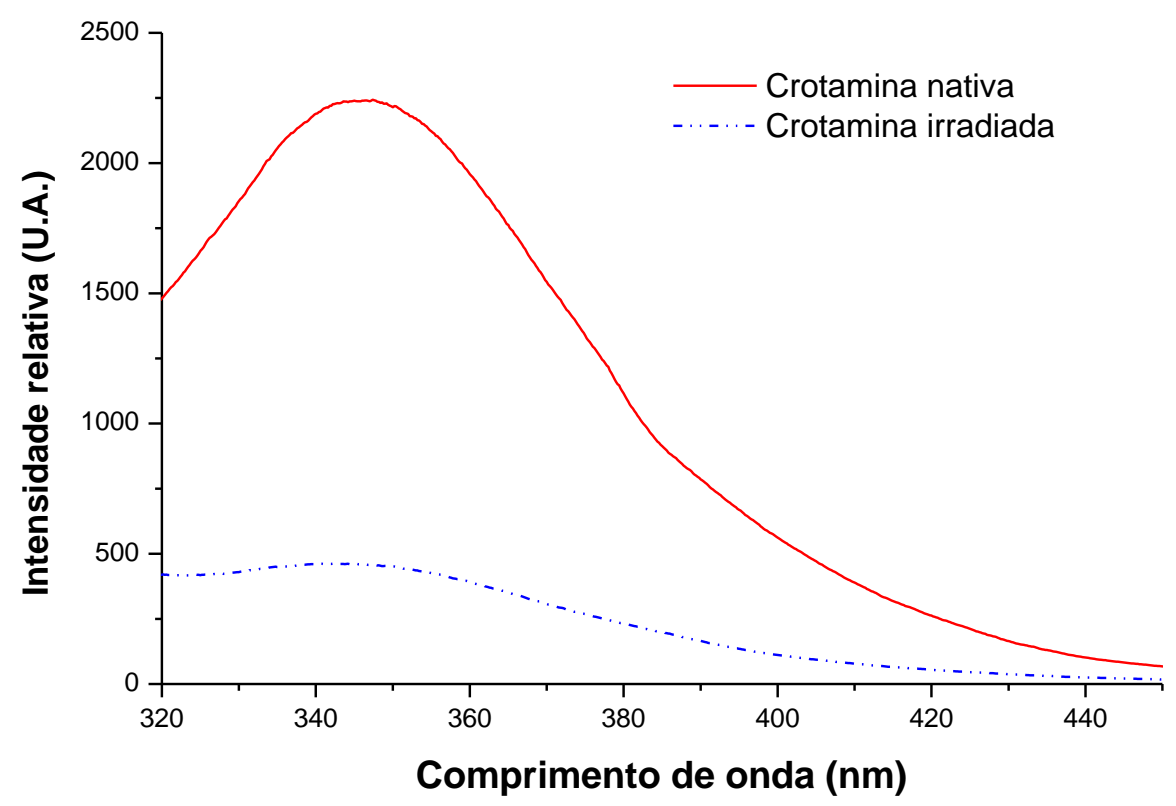

Figura 24: Análise de fluorescência da crotamina nativa e irradiada, ambas na concentração de $400 \mu \mathrm{g} / \mathrm{mL}$ em tampão $\mathrm{NaCl} 150 \mathrm{~mL}$. 


\subsection{Dicroísmo Circular}

A Figura 25 ilustra o perfil da crotoxina nativa e irradiada obtido por CD. Pode-se observar alterações na estrutura secundária da proteína após irradiação nas seguintes regiões: região de transição de folha $\beta$ que compreende o intervalo entre 195 e $200 \mathrm{~nm}$ e o comprimento de onda próximo a $216 \mathrm{~nm}$; e as regiões de 208 - 210 nm e 222 nm que caracterizam transições da estrutura a-hélice.

Os intervalos correspondentes à região de folha $\beta$ podem apresentar imprecisões devido a própria natureza desta estrutura. Assim, as análises de CD são mais sensíveis para a região de a-hélice.

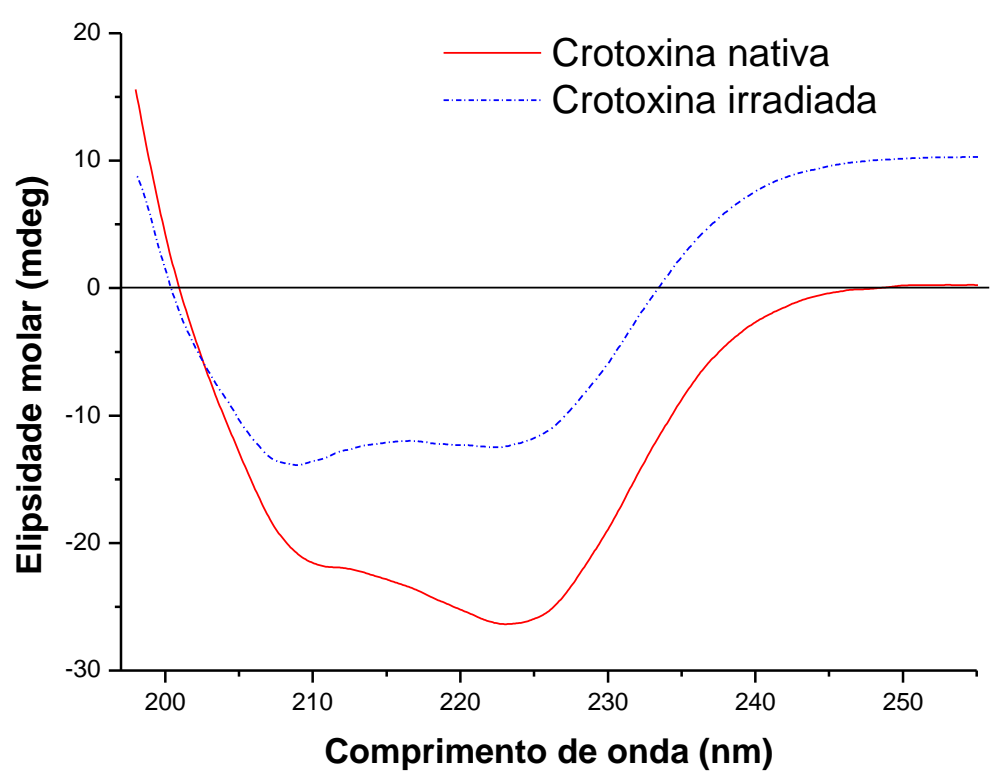

Figura 25: CD da crotoxina nos estados nativo e irradiado. As amostras, na concentração de $400 \mu \mathrm{g} / \mathrm{mL}$, encontravam-se em tampão fosfato, $25 \mathrm{mM}$, pH 7,2. 
A Figura 26 ilustra a análise de CD da crotamina no estado nativo e irradiado. Neste caso também é possível observar alterações na estrutura secundária da proteína após irradiação, principalmente na região de transição de folha $\beta$ (195 e $200 \mathrm{~nm}$ e em $216 \mathrm{~nm}$ ). A primeira região de transição da estrutura a-hélice $(\sim 191-193 \mathrm{~nm})$ e a terceira ( 222 nm) não apresentaram alterações significativas, enquanto que a região de $\sim 208-210 \mathrm{~nm}$ apresentou maior relevância quanto às modificações observadas anteriormente.

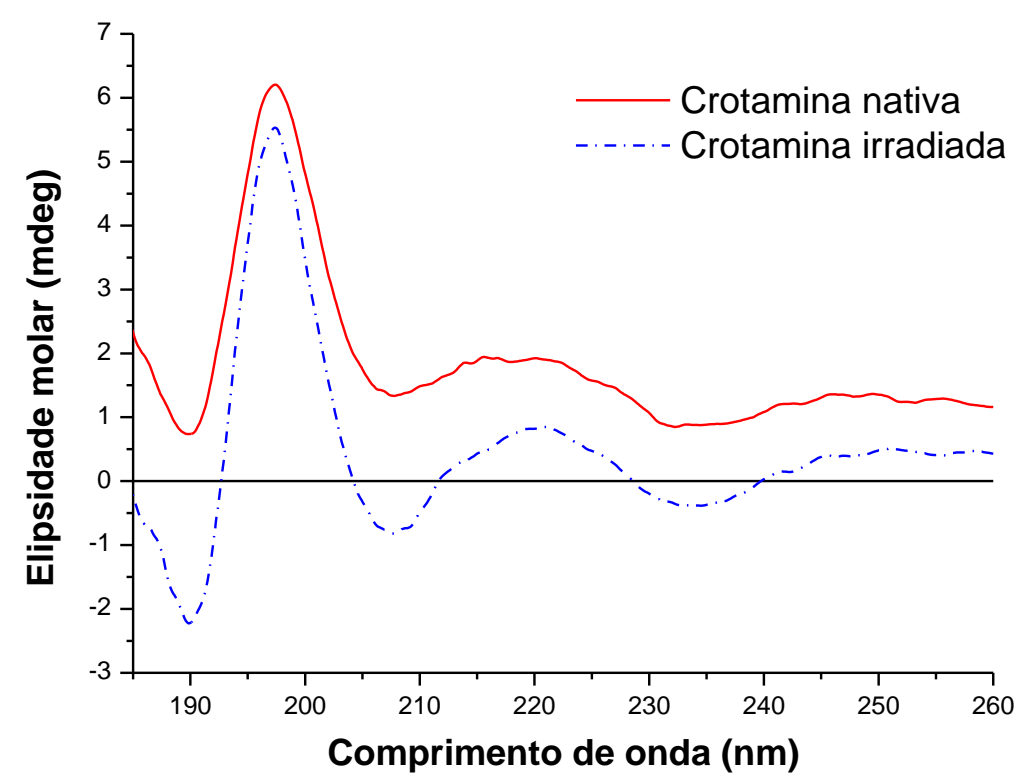

Figura 26: Análise de CD da crotamina nativa e irradiada. As amostras, na concentração de $400 \mu \mathrm{g} / \mathrm{mL}$, encontravamse em tampão fosfato, 25 mM, pH 7,2. 


\subsection{Espectroscopia de Infravermelho}

Na Figura 27 pode-se observar o espectro obtido por ATR-FTIR da crotoxina nativa (curva vermelha) e da toxina irradiada (curva azul). A diferença entre os espectros fica bem caracterizada na região destacada, que representa as áreas das bandas das amidas I e II, regiões extremamente importantes nestas análises, especificamente a banda da amida I.

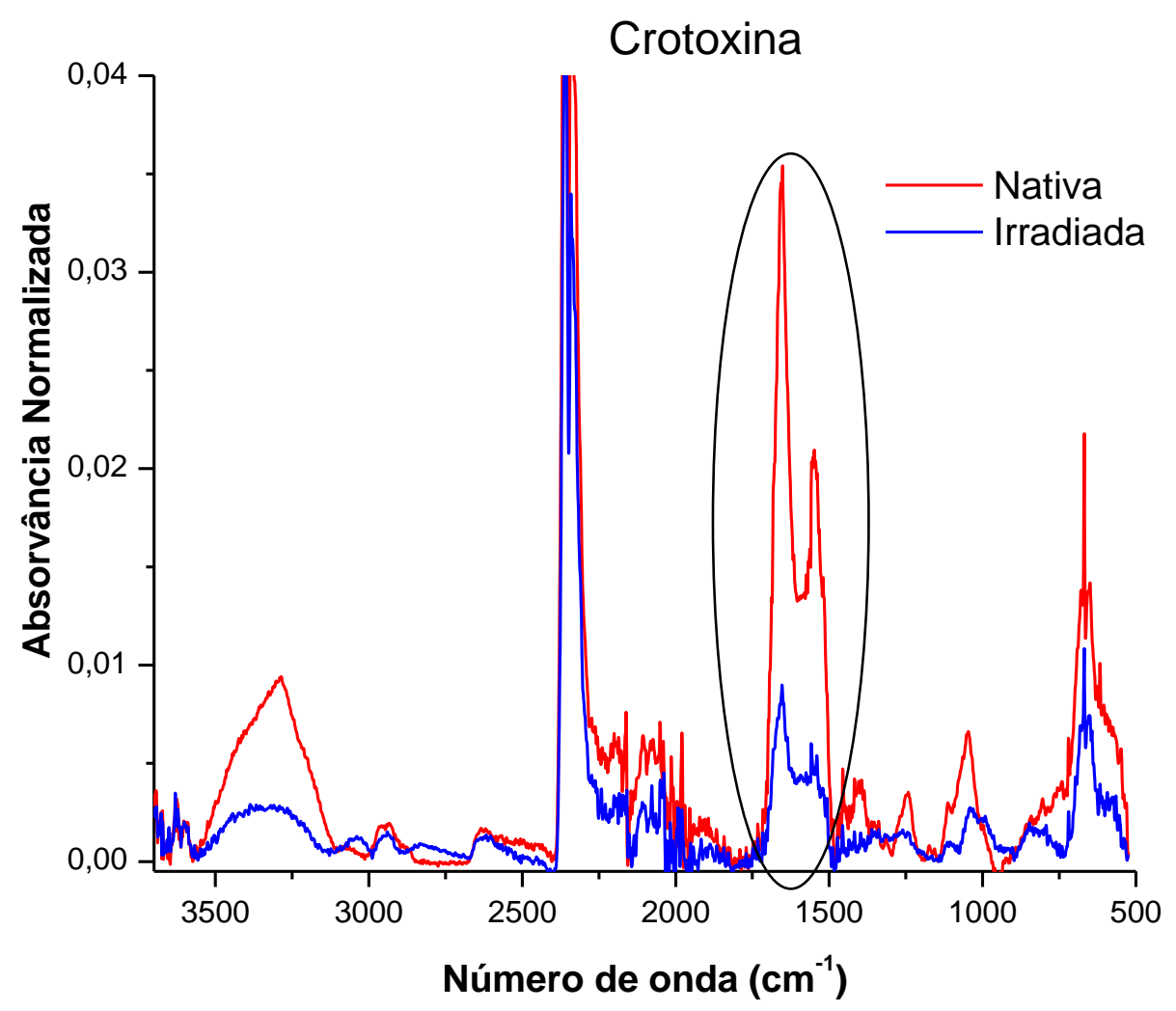

Figura 27: Espectro de ATR-FTIR da crotoxina no estado nativo (curva vermelha) e irradiado (curva azul). 
Na Figura 28 estão apresentados os espectros de ATR-FTIR da crotamina, tanto na forma nativa (curva vermelha), como na irradiada (curva azul). Conforme mencionado anteriormente, devido à importância da região característica das bandas da amida I e II, esta área está em destaque.

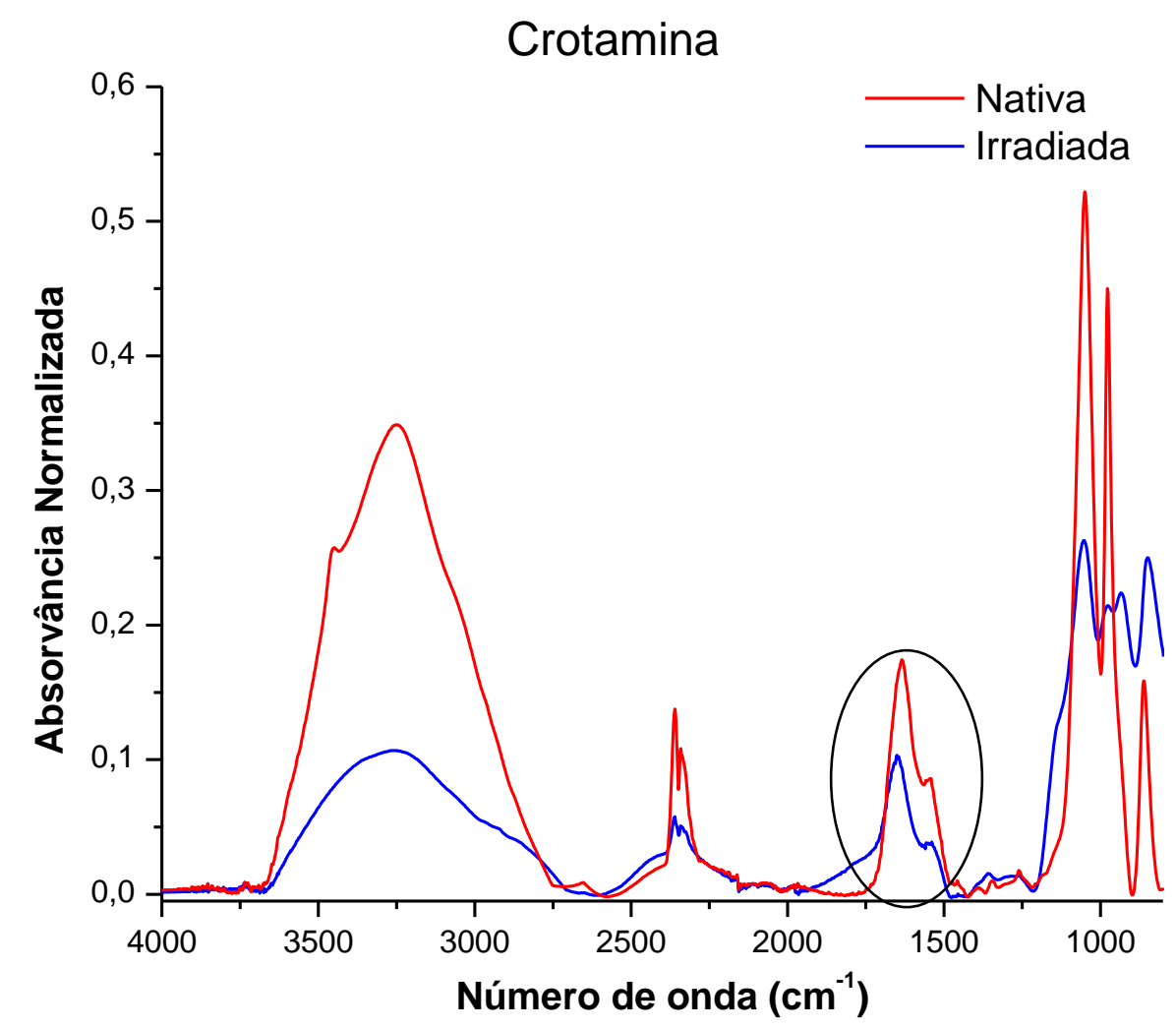

Figura 28: Espectro de ATR-FTIR da crotamina no estado nativo (curva vermelha) e irradiado (curva azul). 
A Figura 29 ilustra o espectro de ATR-FTIR da região da banda da amida I, de maneira ampliada, para a crotoxina nativa (curva vermelha) e para a irradiada (curva azul). Pode-se visualizar que a proteína irradiada possui aumento da intensidade de alguns picos (como por exemplo, as regiões 1, 2, 3), porém não houve um significativo deslocamento dos picos.

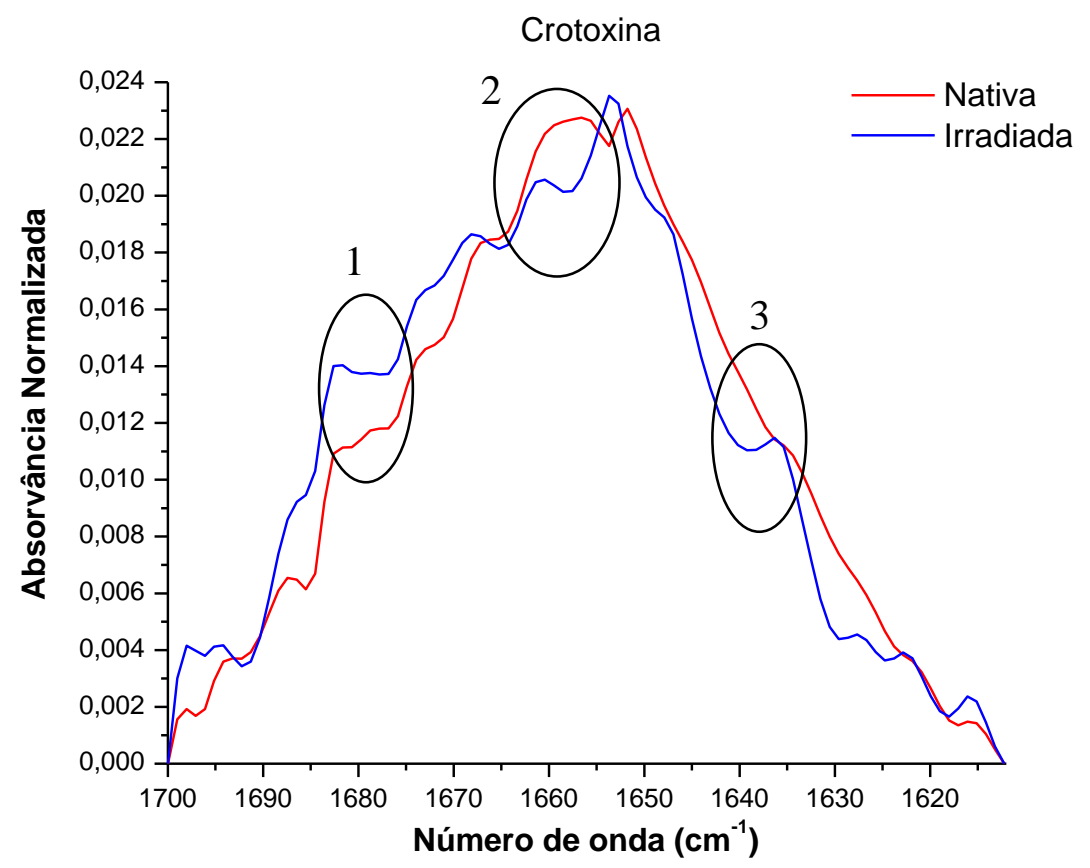

Figura 29: Espectro da região da banda da amida I, obtido por ATR-FTIR, da crotoxina no estado nativo (curva vermelha) e irradiado (curva azul). 
Na Figura 30 é apresentado o espectro ATR-FTIR (região ampliada) da crotamina nativa (curva vermelha) e da irradiada (curva azul). Pode-se visualizar que a proteína irradiada possui um deslocamento do pico da banda e também o aumento da intensidade de alguns picos (como exemplo as regiões 1 , $2,3)$.

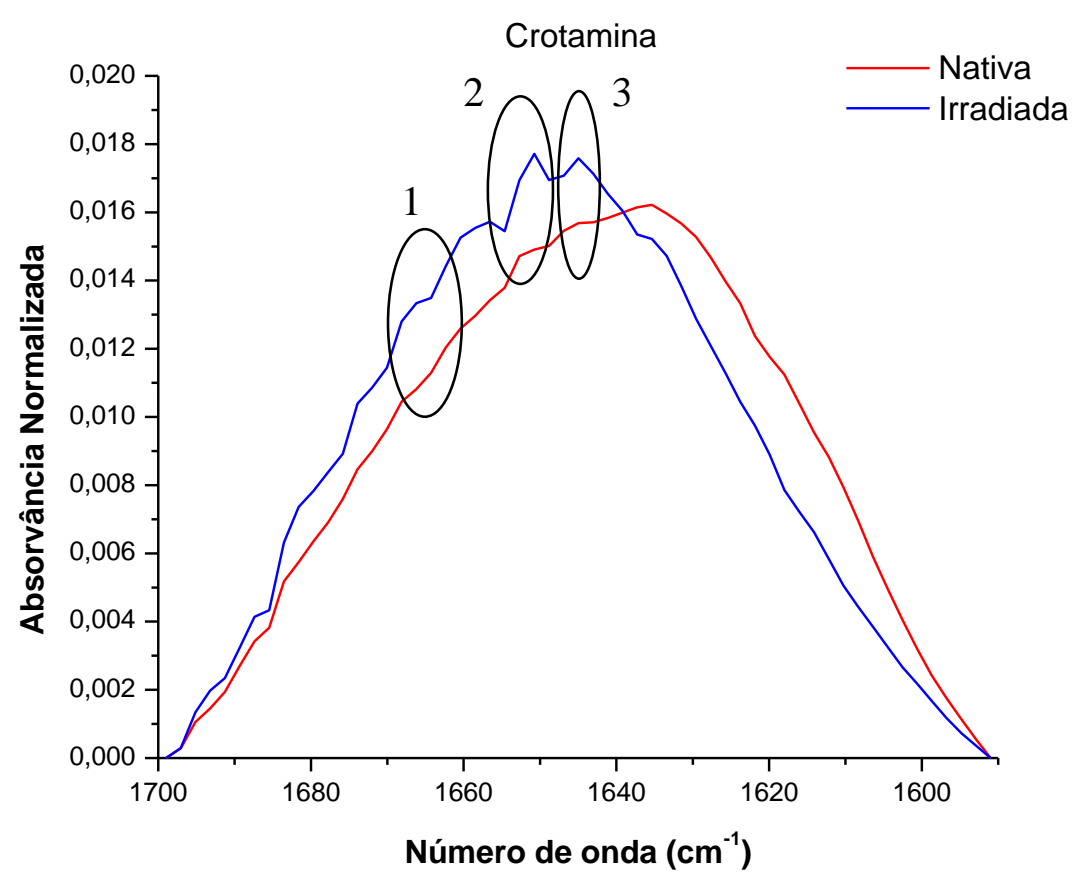

Figura 30: Espectro da região da banda da amida I, obtido por ATR-FTIR, da crotamina no estado nativo (curva vermelha) e irradiado (curva azul). 
Na Figura 31 é mostrado o espectro da segunda derivada referente à crotoxina (nativa e irradiada). É possível observar que a intensidade relativa da proteína irradiada é maior que na nativa, além de um evidente deslocamento dos picos. Tais diferenças são relevantes na técnica de ATR-FTIR.

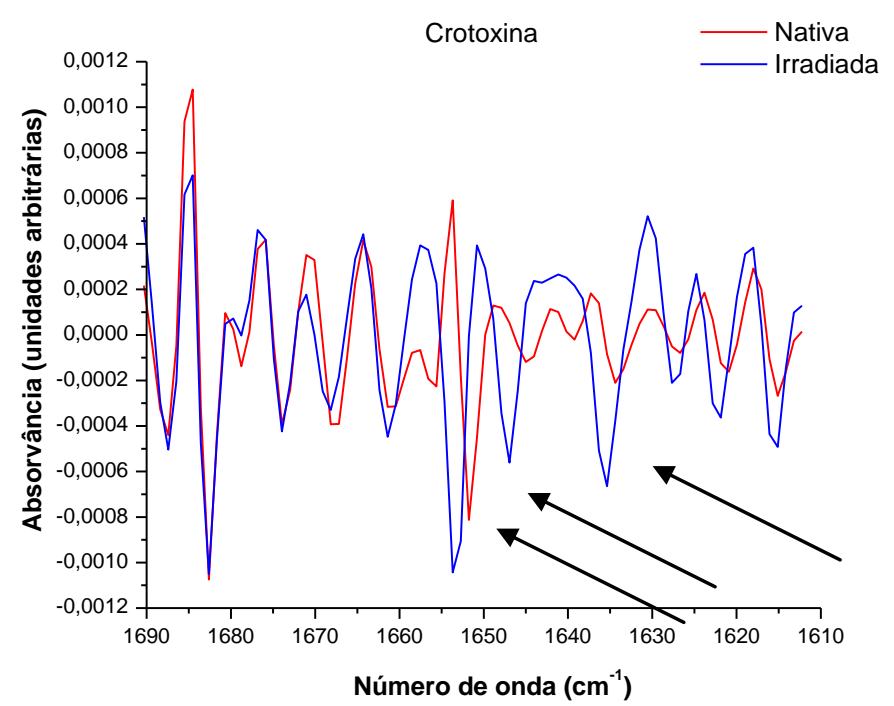

Figura 31: Espectros de ATR-FTIR (segunda derivada) da crotoxina nativa (curva vermelha) e irradiada (curva azul).

A Figura 32 ilustra o espectro da segunda derivada, porém agora, referente à crotamina nativa e irradiada. Neste caso observa-se também a maior intensidade relativa na proteína irradiada em comparação à proteína nativa, além de se evidenciar um deslocamento dos picos, fato que também ocorreu para a crotoxina.

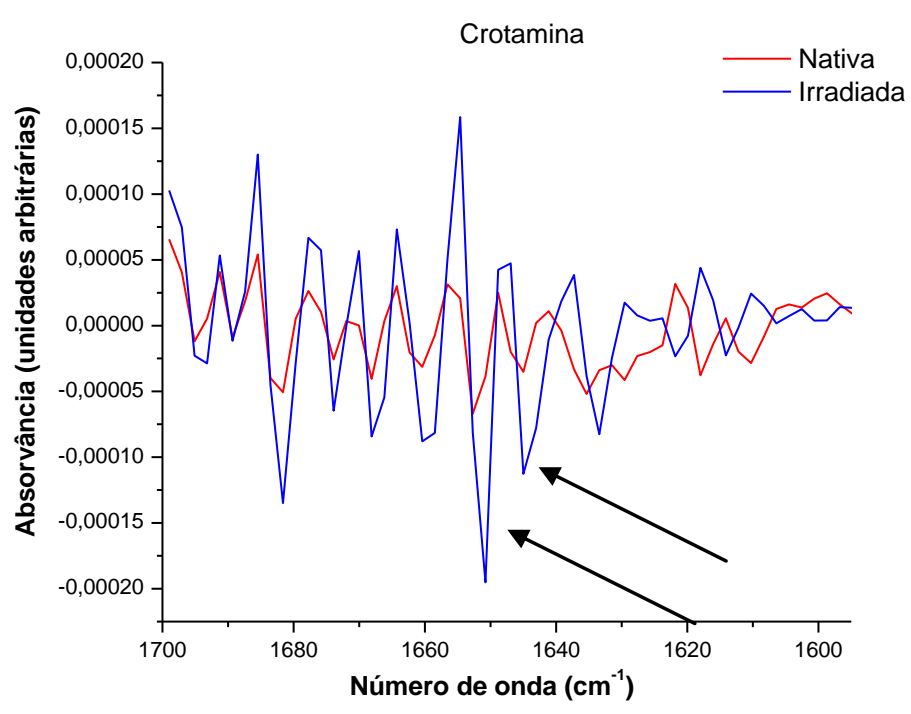

Figura 32: Espectros de ATR-FTIR (segunda derivada) da crotamina nativa (curva vermelha) e irradiada (curva azul). 
A Figura 33 ilustra o histograma obtido a partir das frações que correspondem à estrutura secundária da crotoxina, evidenciando que a proteína nativa tem uma maior quantidade de $\alpha$-hélice. Após o processo de irradiação, há a diminuição de $\beta$-turns, aumento de folha $\beta$ e uma redução significativa de $\alpha$-hélice.

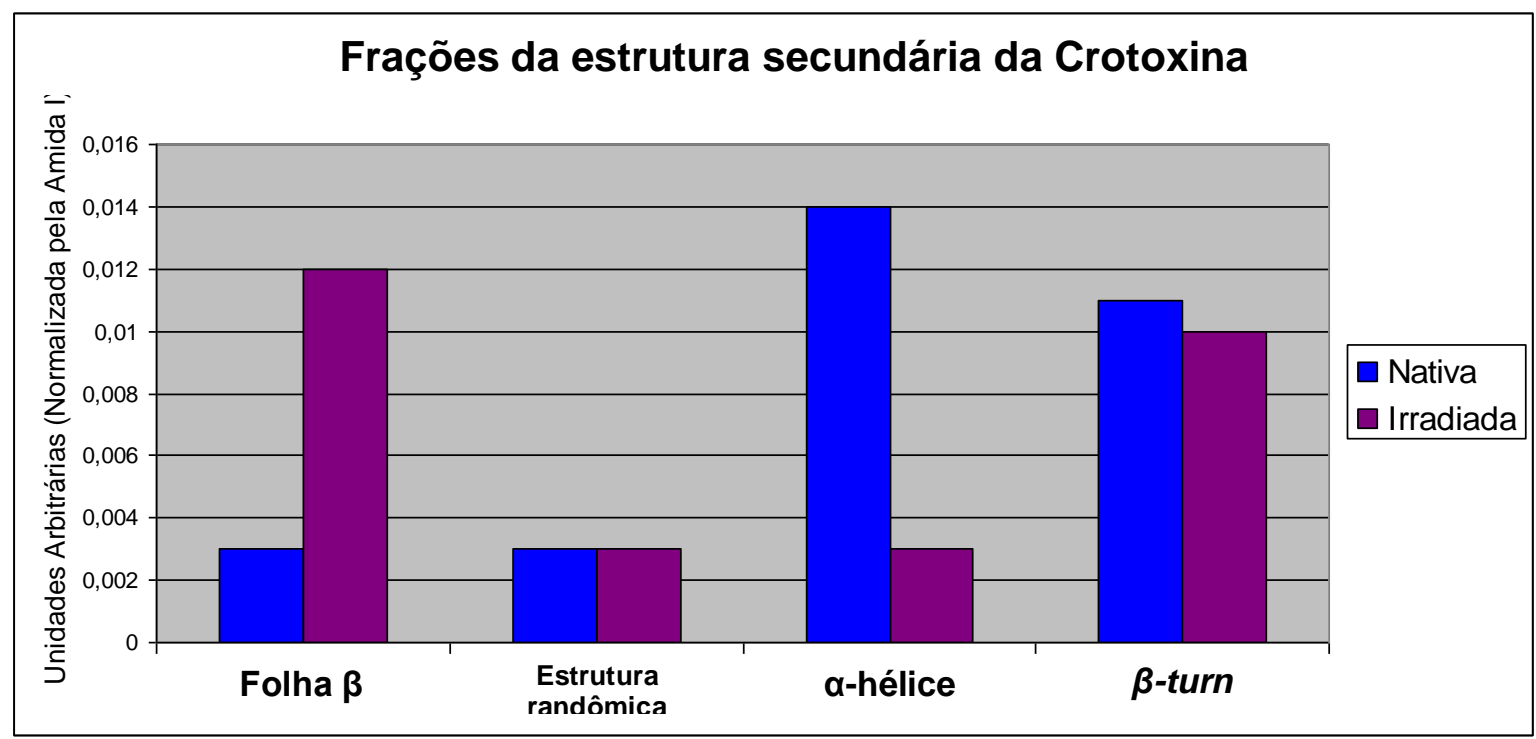

Figura 33: Histograma das frações da estrutura secundária da crotoxina, comparando as quantidades estruturais encontradas na amostra nativa (barras azuis) e irradiada (barras roxas). 
A Figura 34 ilustra o histograma obtido a partir das frações correspondentes à estrutura secundária da crotamina, evidenciando que a proteína nativa tem uma maior quantidade de folha $\beta$ antes da irradiação. Após a irradiação da toxina, há o surgimento de quantidades significativas de estrutura randômica, $\alpha$-hélice e $\beta$-turns.

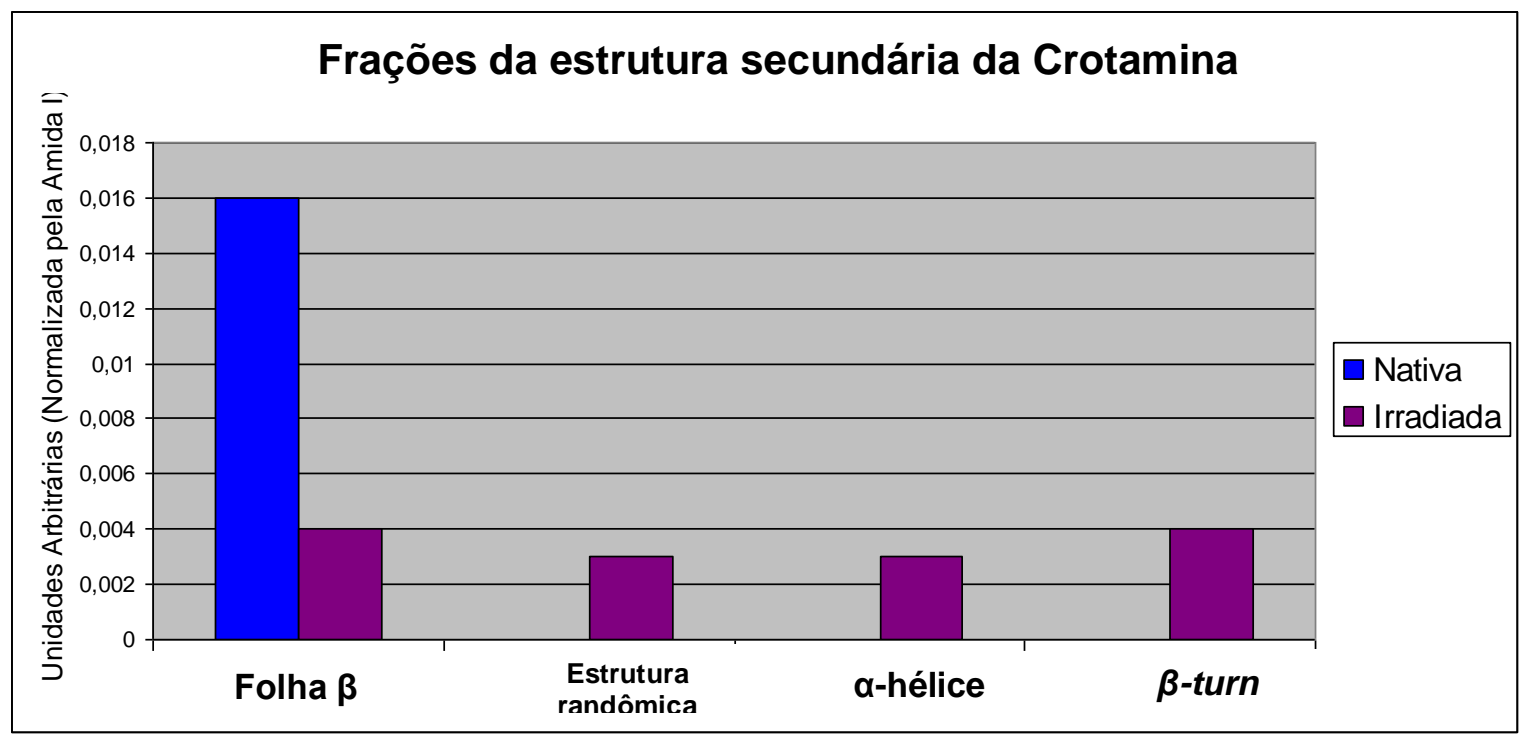

Figura 34: Histograma das frações da estrutura secundária da crotamina, comparando as quantidades estruturais encontradas na amostra nativa (barras azuis) e irradiada (barras roxas). 


\subsection{Calorimetria Diferencial}

A Figura 35 ilustra os perfis calorimétricos das amostras de crotoxina na forma nativa $(\mathbf{A})$ e na forma irradiada (B). Pode-se observar que a crotoxina nativa apresentou a última transição significativa a aproximadamente $72 \stackrel{\circ}{ } \mathrm{C}$, enquanto que para a toxina irradiada, tal transição ocorreu a temperatura de cerca de $40 \stackrel{\circ}{\mathrm{C}}$.
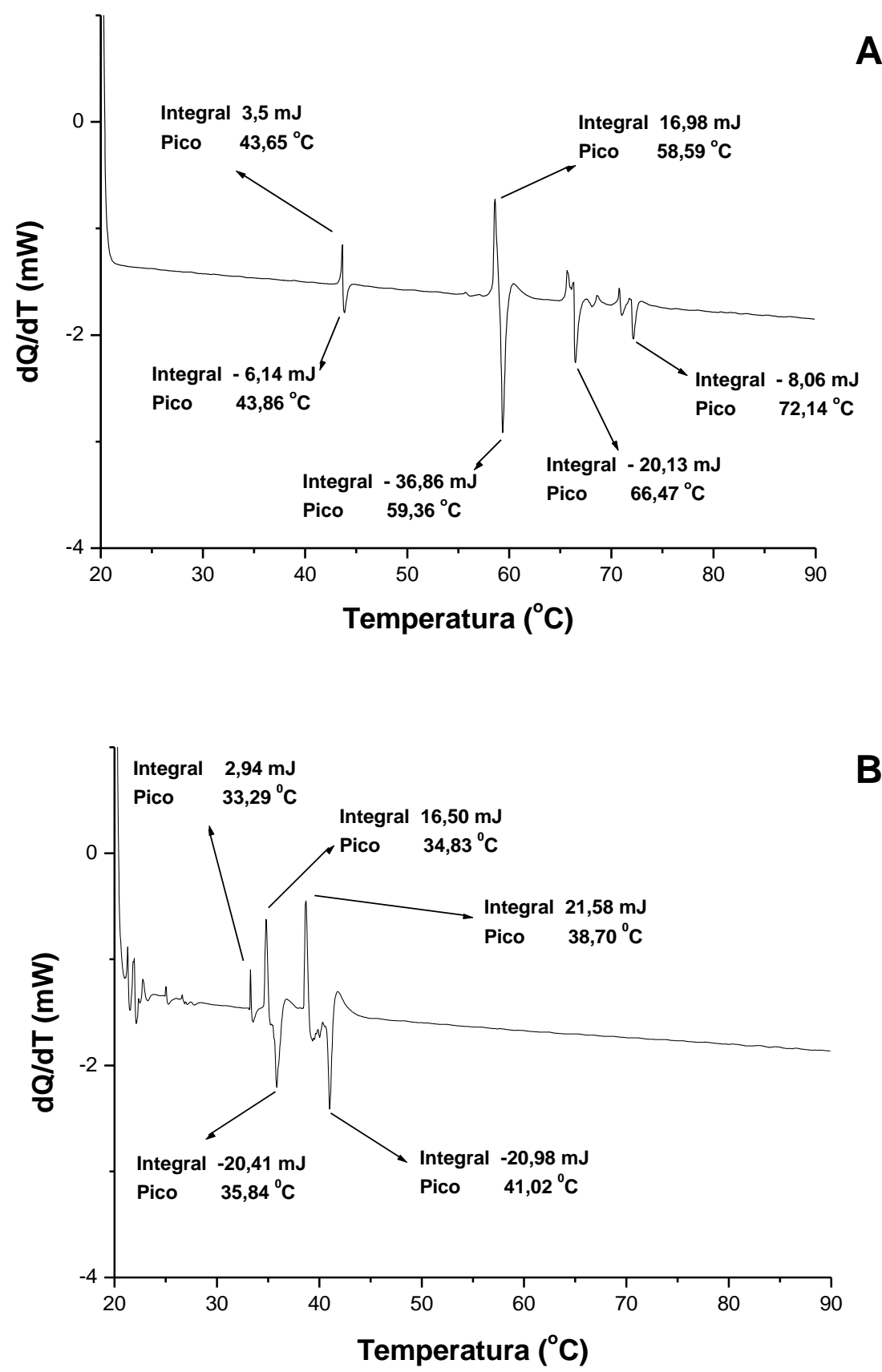

Figura 35: Análise de calorimetria diferencial da crotoxina nativa (A) e irradiada (B), ambas na concentração de $2 \mathrm{mg} / \mathrm{mL}$, em solução salina, $150 \mathrm{mM}$. 
Na Figura 36 está ilustrado o perfil calorimétrico da crotamina nativa (A) e irradiada (B). Pode-se observar uma diferença significativa entre os dois gráficos, uma vez que a temperatura requerida na desnaturação da proteína nativa e irradiada mostrou-se desigual, bem como a quantidade de calor necessária para cada transição energética. No caso da amostra nativa, observase o último pico de transição a temperatura de aproximadamente $45^{\circ} \mathrm{C}$. Para a crotamina irradiada, tal temperatura ficou em torno de $26{ }^{\circ} \mathrm{C}$.
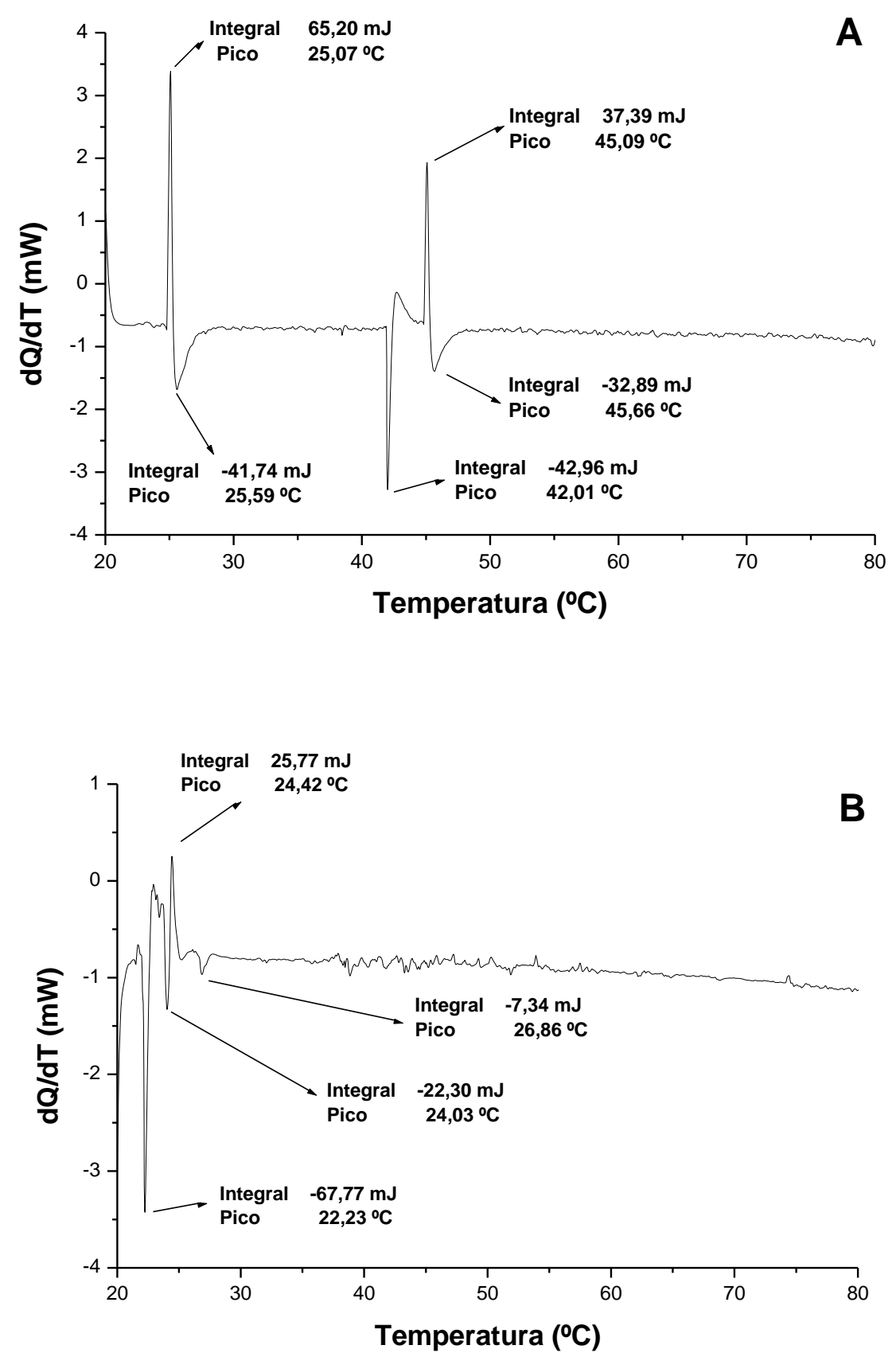

Figura 36: Análise de calorimetria diferencial da crotamina nativa (A) e irradiada (B), ambas na concentração de 400 $\mu \mathrm{g} / \mathrm{mL}$, em solução salina, $150 \mathrm{mM}$. 


\section{DISCUSSÃO}

O envenenamento por picada de serpente representa um sério problema de Saúde Pública, especialmente em áreas tropicais. Calmette (1907) já definia a soroterapia como o melhor meio terapêutico e também destacava a relação direta entre a especificidade do anti-soro para o gênero da serpente e a eficiência do tratamento.

No Brasil, os equinos são empregados na produção de soro contra o veneno de nossas serpentes desde 1901 (Vital Brazil). Embora estes animais apresentem grande porte, sofrem durante o processo de imunização, pois devido à baixa imunogenicidade, grandes quantidades de veneno são inoculadas a fim de obter-se uma produção eficiente de anticorpos, o que afeta diretamente sua longevidade e condições de bem estar (Rosenfeld, 1971).

Com o intuito de melhorar a produção de soro e bem estar dos animais, Phisalix \& Bertrand (1894) realizaram os primeiros estudos objetivando diminuir a toxicidade dos venenos utilizados na imunização de equinos. Desde então, diversos processos têm sido utilizados com o propósito de diminuir a letalidade das toxinas, como por exemplo: iodação (Heneine e col., 1992; Daniel e cols., 1987; Bicalho e cols., 1990), fotooxidação (Shortt \& Mallick, 1935), irradiação com raios-X (Flowers, 1963), ultravioleta (Tejasen \& Ottolenghi, 1970) e mutagênese sítio dirigida (Li e cols., 1994).

A radiação ionizante, a exemplo das metodologias citadas anteriormente, vem sendo utilizada na destoxicação de venenos de serpentes. Esta técnica apresenta um diferencial em relação às demais, visto que além de conseguir diminuir a toxicidade do veneno, mantém, ou por vezes até melhora, as propriedades imunológicas da amostra irradiada, sem que seja adicionada outra substância a mesma (Puranananda, 1972; Kankonkar e cols., 1975; Hati e cols., 1989; Mandal e cols., 1991, 1993).

O grupo de biofármacos do Centro de Biotecnologia do IPEN, principalmente após a crise na produção de soro antiofídico agravada em 1984, tem desenvolvido pesquisas relacionadas à radiação ionizante e seus efeitos sobre venenos de serpentes (Murata, 1988; Nascimento, 1991, 1995; Guarnieri, 1992; Cardi e cols., 1992; Clissa, 1997). O mesmo grupo ainda desenvolveu 
trabalhos que mostraram a ação dos principais produtos gerados na radiólise da água, elétron aquoso e radical hidroxil, sobre a estrutura de toxinas, e identificaram o produto mais danoso à molécula de acordo com a administração de scavengers específicos, cuja função seria reagir com determinada espécie de radical livre (Andriani, 1995; Casare, 2003, 2009). Além disso, outros estudos revelaram o comportamento do sistema imunológico frente à toxina irradiada (Baptista, 2004, 2009; Caproni, 2009).

Embora todos estes trabalhos tenham contribuído para o melhor entendimento da ação da radiação ionizante sobre as proteínas dos venenos de serpentes brasileiras, ainda persistem questionamentos quanto às mudanças estruturais ocasionadas por esse processo físico.

A determinação da conformação estrutural pode promover um sólido entendimento da função biológica da proteína (Peltron \& McLean, 2000). Considerando que as alterações observadas em toxinas irradiadas, como a diminuição da toxicidade e a manutenção de propriedades imunológicas, apresentam-se como consequências de alterações conformacionais, o entendimento das mudanças estruturais nas proteínas irradiadas poderia esclarecer como tais processos modificam as funções biológicas e imunológicas das toxinas de venenos.

A gravidade dos acidentes envolvendo cascavéis aliada ao fato do veneno destas serpentes apresentarem poucos componentes, com alguns deles bem caracterizados do ponto de vista biológico e imunológico, nas formas nativa e irradiada, serviram de pilares para o desenvolvimento do presente trabalho que tem como foco principal análises estruturais da crotoxina e da crotamina, duas toxinas do veneno de C.d.terrificus.

Para dar início ao estudo, o veneno total da C.d.terrificus foi submetido a técnicas cromatográficas com o objetivo de isolar as proteínas de interesse, crotoxina e crotamina. A primeira etapa realizada no fracionamento do veneno bruto foi a cromatografia de exclusão molecular, baseada no tamanho das moléculas dos componentes, onde foi possível observar a separação de 5 frações: convulxina (pico 1), delta-toxina (pico 2), giroxina (pico 3), crotoxina (pico 4) e crotamina (pico 5), o que corrobora os achados de Clissa (1997). Observouse ainda que os picos 4 e 5 , referentes à crotoxina e crotamina, respectivamente, 
foram os mais representativos, sendo que, de acordo com a Tabela 2, a área do pico da crotoxina, em relação à área total do cromatograma, corresponde a aproximadamente $63 \%$, enquanto a área do pico da crotamina representa cerca de $21 \%$ do total. Estes dados estão de acordo com os achados de Slotta \& Fraenkel-Conrat (1938), Gonçalves \& Arantes (1956) e outros trabalhos mais recentes (Boni-Mitake, 2000; Casare, 2009). Um perfil de eluição muito similar ao obtido na Figura 14, cromatografia de exclusão molecular, é verificado em todos os casos de veneno crotálico, exceto para venenos de cascavéis crotaminanegativa, que não apresentam o pico 5 (Boni-Mitake, 2000).

As serpentes que possuem venenos crotamina-positiva são encontradas a oeste do Estado de São Paulo e os crotamina-negativa, ao leste do Estado. Existe, porém, uma região híbrida, na qual coexistem os dois tipos de venenos (Schenberg, 1959). O fracionamento observado neste cromatograma deixa evidente que tanto a crotoxina como a crotamina apresentam contaminantes. No caso da crotoxina, os principais são a giroxina e a crotamina. E para a crotamina o principal contaminante é a crotoxina.

Uma segunda etapa cromatográfica foi realizada para a obtenção das toxinas com alto grau de homogeneidade. A técnica cromatográfica por troca iônica foi utilizada tanto para a crotoxina, como para a crotamina. No caso da crotoxina (Figura 15), utilizou-se uma coluna de troca aniônica, cujo princípio de separação baseia-se na adsorção à resina de compostos carregados negativamente, configuração eletrônica que pode ser obtida em soluções cujo pH está acima do pl da proteína. Foi possível observar que 4 picos (picos 3 a 6 da Tabela 3) formaram a fração correspondente à crotoxina. Isto se deve ao fato desta toxina apresentar diversas isoformas, consequência, em muitos casos, da alteração de apenas um aminoácido. Em 1987, Faure \& Bon, por meio de técnicas cromatográficas e eletroforéticas, evidenciaram que existe pelo menos 15 isoformas de crotoxina e que a heterogeneidade das isoformas é tão grande em algumas amostras de veneno de uma mesma espécie de serpente quanto de uma mistura de amostras de várias espécies. Hernadez-Oliveira e cols. (2005) caracterizaram uma nova $\mathrm{PLA}_{2}(\mathrm{~F} 16)$ do veneno da C.d.terrificus. Assim, a crotoxina pode ser considerada como uma variante de diferentes isoformas de suas subunidades, crotapotina e PLA 2 (Faure \& Bon, 1988; Faure e cols., 1993). 
Estes 4 picos, de acordo com a Tabela 3, representam aproximadamente 83\% da área total do cromatograma. O pico não retido, ou seja, aquele não adsorvido à coluna foi eluído na primeira fração observada na Figura 15, como esperado.

No caso da crotamina (Figura 16), utilizou-se uma coluna de troca catiônica. Para esta etapa cromatográfica, a proteína deve adquirir uma configuração eletrônica positiva, estando, portanto, em um tampão com pH menor do que o pl da proteína. Com base na Figura 16 foi possível verificar que o pico da crotamina mostrou-se assimétrico, ou seja, ocorreu a formação de um "ombro", tanto na parte ascendente do pico, como na descendente. Estes dados reforçam a idéia da existência de isoformas da crotamina, uma vez que se partiu do pool do veneno total da C.d.terrificus onde possivelmente coexistem isoformas da toxina. Como já citado para a crotoxina, a mudança de um único aminoácido na sequência primária da proteína pode resultar em isoformas. Toyama e cols. (2000) isolaram, por meio de um único passo de RP-HPLC, isoformas denominadas F2 e F3, cujas estruturas terciárias mostraram-se idênticas, diferindo em um ou dois aminoácidos apenas. Além disso, observou-se também o pico não retido, como esperado.

$\mathrm{Na}$ intenção de verificar a origem da assimetria do pico da crotamina observado na Figura 16, comprovando se este fato realmente é devido à presença de isoformas, realizou-se uma cromatografia de fase reversa (RPHPLC). Nesta técnica cromatográfica os componentes são separados pela hidrofobicidade, sendo que aqueles de maior polaridade (menos hidrofóbicos) são eluídos primeiramente. Na Figura 22 observou-se o perfil cromatográfico obtido na fase reversa em coluna C-8, com $0,05 \%$ de ácido fórmico e gradiente de acetonitrila. Foram verificados 2 picos, cuja eluição ocorreu em aproximadamente $30 \%$ do tampão B (acetonitrila). Toyama e cols. (2000) obtiveram as isoformas F2 e F3, posteriormente comprovadas por espectrometria de massa, em condições amostrais diferentes daquelas utilizadas neste trabalho, porém a eluição ocorreu de forma semelhante. Assim, os picos obtidos na RP-HPLC, possivelmente representam isoformas da crotamina.

Após cada etapa cromatográfica foram realizadas cromatografias analíticas em coluna de gel filtração para verificar a eficiência dos processos de fracionamento. Num primeiro momento, as amostras de crotoxina e crotamina 
provenientes da exclusão molecular foram analisadas (Figuras 17 e 18). Observou-se na Figura 17, que o pico correspondente à crotoxina representou aproximadamente $85 \%$ da área total do perfil (Tabela 5). Porém, nesta fase, outros 2 picos ainda foram identificados: um com massa molecular maior do que a crotoxina (eluído anteriormente) e provavelmente correspondente à giroxina, e outro com massa molecular inferior a da crotoxina (eluído posteriormente), possivelmente representando a crotamina. Tais toxinas, como já observado na Figura 14, são os principais contaminantes da crotoxina.

As mesmas condições cromatográficas utilizadas para a crotoxina foram mantidas em relação à crotamina. Na Figura 18 observou-se que o pico correspondente à toxina de interesse representou cerca de $81 \%$ da área total do cromatograma. Dois outros picos também foram observados nesse caso, um com menor volume de eluição (maior massa molecular) do que o pico da crotamina, correspondendo possivelmente à crotoxina, e o outro eluído em volume maior (menor massa molecular), provavelmente representando peptídeos presentes no veneno da C.d.terrificus. Mais recentemente, alguns trabalhos têm demonstrado a relevância de peptídeos bioativos (BPP) presentes nos venenos de serpentes. Silva e cols. (2007) sugeriram um novo mecanismo de ação para a atividade antihipertensiva do BPP 10c, um decapeptídeo bioativo do veneno da Bothrops jararaca.

A análise em gel filtração analítica citada acima foi reproduzida com a crotoxina e com a crotamina (Figuras 19 e 20) após a segunda etapa cromatográfica (troca iônica) e posteriormente ao processo de diálise. Na Figura 19, na qual está ilustrado o perfil da crotoxina, observou-se um pico majoritário, que representou aproximadamente $96 \%$ da área total do cromatograma (Tabela 7). Este resultado mostrou que as duas etapas cromatográficas utilizadas para 0 isolamento da crotoxina foram extremamente satisfatórias considerando o propósito do trabalho.

Em relação à Figura 20, verificou-se que o pico correspondente à crotamina, identificado de acordo com o volume de eluição obtido em outras cromatografias de exclusão molecular na mesma coluna de gel filtração, foi de pouca relevância em relação ao pico eluído posteriormente, considerando a área total do cromatograma (Tabela 8). 
Uma possível explicação para o ocorrido é que o segundo pico represente componentes de menor massa molecular, resultantes de quebras na proteína, ou ainda alguma contaminação decorrente da segunda etapa de purificação ou da diálise em membrana. No caso do processo de diálise, possivelmente o limite dos poros da membrana não se mostrou apropriado à diálise da crotamina devido à baixa massa molecular desta toxina (4,8 kDa), e além de realizar a troca do tampão fosfato de sódio (proveniente da troca iônica) por água, ocasionou também a perda da toxina, resultando em uma leitura da absorvância inferior ao esperado. No intuito de minimizar essas perdas, a amostra de crotamina após cromatografia de troca iônica foi aplicada a uma coluna de desalting (Sephadex G-10), capaz de separar estruturas iônicas - baixa massa molecular - daquelas de maior massa molecular. De acordo com o perfil observado na Figura 21, fica evidente que esta técnica mostrou-se eficaz na separação entre o sal e a amostra, visto que o pico da condutividade, representativo da eluição dos íons de $\mathrm{NaCl}$ em solução, ficou distante do pico da toxina de interesse.

Como já mencionado anteriormente, a irradiação de proteínas em solução aquosa pode induzir uma série de alterações na estrutura protéica e por consequência, nas propriedades físico-químicas desta, indo desde simples ionizações, até alterações drásticas na sua estrutura primária, secundária e terciária. Tais mudanças estão relacionadas com a perda da atividade biológica além de poder interferir nas propriedades imunológicas após a irradiação (Grosch \& Hoopywood, 1979).

Assim, estudos relacionados à investigação da conformação estrutural, bem como a estabilidade protéica após o processo de irradiação, tornaram-se o objetivo principal deste trabalho.

Para este propósito, 4 técnicas foram escolhidas: Fluorescência, Dicroísmo Circular, Calorimetria Diferencial e Espectroscopia de Infravermelho.

A Fluorescência é uma técnica relevante quanto à indicação de alterações estruturais em moléculas protéicas, principalmente em relação aos compostos aromáticos, como triptofano, fenilalanina e tirosina. Estes resíduos, quando excitados por radiação ultravioleta, em comprimento de onda específico, retornam ao estado fundamental por meio da emissão de fluorescência. A 
fluorescência ocorre sempre a uma menor frequência (menor energia), em relação à radiação incidente, uma vez que a transição de emissão acontece após parte da energia vibracional ser descartada para a vizinhança (Atkins, 1998). Dessa maneira, observa-se que o comprimento de onda da emissão de fluorescência é sempre maior do que o utilizado na excitação do cromóforo.

A análise das proteínas por Fluorescência permitiu a abordagem da mudança estrutural frente à exposição dos resíduos de triptofano, que são os mais amplamente estudados, e estão presentes tanto na crotoxina, como na crotamina.

O triptofano ocorre em um ou poucos resíduos na maioria das proteínas e peptídeos biologicamente ativos. A fluorescência do cromóforo é altamente sensível ao meio no qual a proteína se encontra. Assim, a intensidade relativa na emissão de fluorescência depende da natureza e da disposição de grupos funcionais da proteína, bem como das moléculas de água ao redor do triptofano (Chen \& Barkley, 1998).

No caso da crotoxina, um complexo heterodimérico formado por uma subunidade ácida (crotapotina) e outra subunidade básica $\left(P L A_{2}\right)$, observa-se a presença de apenas um triptofano na crotapotina e três resíduos na PLA 2 (Hendon \& Fraenkel-Conrat, 1971; Hanley, 1979). Na Figura 23 identificou-se uma discreta diferença de intensidade entre o espectro da amostra nativa e o da irradiada. $O$ deslocamento para a direita (região do vermelho), de $5 \mathrm{~nm}$, do pico da crotoxina irradiada em relação ao da crotoxina nativa, pode inferir uma possível alteração no complexo estrutural, uma vez que deslocamentos para esta região do espectro implicam em maior comprimento de onda e, portanto, menor energia, sugerindo gasto de energia em interações do triptofano não relacionadas com a emissão de fluorescência.

Hanley (1979) mostrou em um estudo conformacional do complexo crotoxina e de suas subunidades isoladas, que para valores de $\mathrm{pH}$ entre 4 e 10, o espectro de fluorescência obtido da crotoxina não é representado pelo espectro obtido frente à contribuição das subunidades. Tais espectros indicaram ainda que a formação do complexo foi acompanhada por uma redução em $70 \%$ da intensidade da emissão de fluorescência e uma mudança de $7 \mathrm{~nm}$ para a região do azul no pico de emissão máxima. 
Aird e cols. (1989) também observaram que o quenching de fluorescência do complexo de 3 crotoxinas homólogas diminuiu de $50 \%$ a $80 \%$ comparando-se toxinas intactas e suas subunidades. Esses achados sugeriram ainda que o aumento da fluorescência exibido pelas subunidades isoladas é um artefato resultante de mudanças estruturais irreversíveis.

Considerando que a radiação ionizante induz quebras na estrutura protéica, o que possivelmente leva a crotoxina a um estado conformacional onde as subunidades encontrem-se separadas, a diminuição do quenching de fluorescência observada no espectro da amostra nativa em comparação com o da irradiada (Figura 23), corrobora, em partes, o apresentado por Aird e cols. (1989) e Hanley (1979), uma vez que, de acordo com os dados aqui mostrados, a redução foi de aproximadamente $10 \%$. Essa pequena diferença na redução do espectro de fluorescência pode sugerir que uma dissociação entre as subunidades da crotoxina ocorra quando a mesma é submetida a condições de baixos valores de $\mathrm{pH}$. Tal fato é observado, por exemplo, na primeira etapa de fracionamento, onde o tampão formiato apresenta $\mathrm{pH} 3,0$. Mesmo que na etapa seguinte, a crotoxina se encontre em um tampão cujo $\mathrm{pH}$ é 8,2, não necessariamente todas as subunidades dissociadas serão favorecidas quanto à provável associação.

Além disso, o deslocamento observado entre os espectros de fluorescência da amostra de crotoxina nativa e irradiada está de acordo com a literatura, porém, Hanley (1979) observou uma alteração de $7 \mathrm{~nm}$ e neste trabalho foi observado um deslocamento de $5 \mathrm{~nm}$, mostrando que o deslocamento pode ser representativo de possíveis alterações conformacionais na estrutura terciária da crotoxina.

$\mathrm{Na}$ avaliação dos resultados referentes à crotamina (Figura 24), toxina que apresenta apenas dois resíduos de triptofano, fica evidente a diminuição da intensidade de fluorescência comparando-se os perfis espectrais da proteína nativa e irradiada. Considerando-se que o resíduo de triptofano na molécula de crotamina nativa encontra-se em uma região pouco acessível ao solvente, uma alteração estrutural poderia expor tal resíduo, tornando-o mais acessível e consequentemente diminuindo o seu quenching de fluorescência, uma vez que parte da energia poderia ser perdida em demais interações. 
Davies (1987) mostrou que a exposição de diversas proteínas a produtos oxidativos gerados na radiólise da água, principalmente o radical hidroxil $(\mathrm{OH} \bullet)$, induziu a perda da fluorescência do triptofano nativo. Sugura e cols. (2003) evidenciaram que o resíduo de triptofano presente no citocromo $c$ sofreu diminuição significativa na emissão de fluorescência quando a amostra foi submetida a 2 kGy. Casare (2009) demonstrou que a análise de aminoácidos da crotamina nativa e irradiada não apresentou diferenças na composição dos aminoácidos, com exceção ao triptofano. Tal fato corrobora os achados de Butler e cols. (1984) que mostraram a maior susceptibilidade de compostos aromáticos à radiação. Assim, o perfil obtido na Figura 24 está de acordo com os dados da literatura.

Embora a Fluorescência seja uma ferramenta importante na identificação de mudanças moleculares, tais medidas são de difícil interpretação em termos de alterações quanto à estrutura secundária ( $\alpha$-hélice e folha $\beta$ ).

Como já citado, a determinação da estrutura secundária de uma proteína pode promover um importante avanço no entendimento de suas funções. Dessa forma, diversos métodos espectroscópicos revelam-se como uma ferramenta essencial no estudo da estrutura secundária, da estabilidade protéica e consequentes agregações.

A estrutura secundária das proteínas é determinada pela disposição de ângulos $(\Phi, \varphi)$ que definem a orientação espacial da cadeia peptídica, e pela presença de ligações de hidrogênio específicas. Quando os ângulos da cadeia apresentam valores repetidos, o peptídeo forma uma estrutura secundária regular. De acordo com a geometria espacial de uma cadeia, são reconhecidas algumas formas estruturais denominadas: $\alpha$-hélice, folha $\beta$ e randômica (Peltron \& McLean, 2000).

Em proteínas solúveis, o comprimento médio da hélice é de 11 resíduos, correspondendo a 3 turns (voltas, giros). Uma vez que as cadeias de grupamentos amida estão envolvidas por ligações de hidrogênio intra cadeia, a interação de hélices com outros peptídeos ou pequenas moléculas ocorre exclusivamente por meio de interações entre cadeias laterais. $\mathrm{Na} \alpha$-hélice, as pontes de hidrogênio entre os grupos $\mathrm{C}=\mathrm{O}$ e $\mathrm{N}-\mathrm{H}$ são bastante estáveis porque os três átomos envolvidos são coplanares (arranjados linearmente). No caso da folha 
$\beta$, a orientação conformacional, tanto na forma paralela como antiparalela, ocorre de acordo com as ligações de hidrogênio na cadeia protéica, e é este fato que estabiliza esta estrutura em proteínas. Ainda em relação à estrutura secundária, pode-se observar outro tipo de conformação denominada $\beta$-turn. Tais estruturas são geralmente encontradas na superfície protéica, local onde as ligações de hidrogênio com o solvente são favorecidas. Por fim, a estrutura randômica é geralmente definida como uma conformação que não é hélice, nem folha e nem turn (Peltron \& McLean, 2000).

Neste estudo, duas técnicas espectroscópicas foram escolhidas para determinar a estrutura secundária da crotoxina e crotamina: Dicroísmo Circular e Infravermelho.

O fenômeno de dicroísmo circular é observado quando moléculas absorvem luz circularmente polarizada para a esquerda e para a direita em diferentes extensões. $O$ cromóforo amida das ligações peptídicas em proteínas domina o espectro de CD abaixo de $250 \mathrm{~nm}$. Em proteínas constituídas por $\alpha$ hélice, uma banda negativa próxima a $222 \mathrm{~nm}$ é observada devido à forte ligação do hidrogênio neste meio conformacional. Esta transição é relativamente independente do comprimento da hélice. Uma segunda transição a $190 \mathrm{~nm}$ é dividida em uma banda negativa próximo de $208 \mathrm{~nm}$ e uma banda positiva perto de $192 \mathrm{~nm}$. Ambas as bandas são reduzidas em hélices curtas. O espectro de CD de folha $\beta$ apresenta uma banda negativa próximo a $216 \mathrm{~nm}$, uma banda positiva entre 195 e $200 \mathrm{~nm}$ e uma banda negativa perto de $175 \mathrm{~nm}$. Entretanto a posição e intensidade destas bandas são variáveis, resultando em uma menor precisão na identificação de estrutura $\beta$ por CD em comparação à $\alpha$-hélice (Peltron \& McLean, 2000).

Sabe-se que quando a estrutura nativa de uma proteína, contendo regiões de $\alpha$-hélice e folha $\beta$, é desnaturada, as proporções entre tais regiões encontradas inicialmente, é alterada.

Na Figura 25 observou-se o perfil espectroscópico, obtido por CD, da crotoxina nativa e da irradiada. O resultado referente ao perfil da estrutura nativa corrobora os achados de Aird e cols. (1989) que analisou de forma comparativa a crotoxina e suas subunidades em 4 venenos do gênero Crotalus. Foi possível verificar uma nítida diferença entre os espectros da toxina nativa e após 
irradiação. A região de $222 \mathrm{~nm}$, característica de $\alpha$-hélice, por meio de equações propostas por Goormaghtigh e cols. (2009), representou cerca de 78,5\% do espectro total para a crotoxina nativa. A mesma análise foi realizada para a crotoxina irradiada, e o valor obtido foi aproximadamente 40\%, comprovando, portanto, uma significativa diminuição da estrutura de a-hélice da amostra irradiada em comparação à toxina nativa. É importante ressaltar que para tais valores há um erro de derivação padrão intrínseco ao método de 8,5\%.

Quanto à estrutura folha $\beta$, a região de $216 \mathrm{~nm}$ mostrou uma diferença significativa entre os perfis da amostra nativa e o da irradiada. Os cálculos realizados para quantificar esta estrutura (Goormaghtigh e cols., 2009) remetem aos valores de 240 e $248 \mathrm{~nm}$. Os valores obtidos mostraram para a amostra nativa aproximadamente $1 \%$ de folha $\beta$, enquanto que para a toxina irradiada, esse valor subiu para cerca de $50 \%$. Neste caso, o erro de derivação padrão pode chegar a $10 \%$.

Hanley (1979) mostrou alguns dados referentes à estrutura secundária da crotoxina, e de suas subunidades isoladas. Na Tabela 9 são apresentados alguns valores comparativos.

Tabela 9: Valores comparativos da estrutura secundária da crotoxina e suas subunidades.

\begin{tabular}{ccc}
\hline Toxina & $\boldsymbol{\alpha}$-hélice (\%) & Estrutura $\boldsymbol{\beta}(\%)$ \\
\hline Crotoxina & 37,5 & 45,0 \\
\hline Crotapotina & 6,0 & 41,0 \\
\hline $\mathrm{PLA}_{2}$ & 15,0 & 38,5 \\
\hline
\end{tabular}

Pode-se verificar uma grande diferença entre os dados mostrados na Tabela 9 e os valores obtidos neste trabalho no sentido de estimar a estrutura secundária da crotoxina pela técnica de CD. Porém, os valores aqui apresentados, mostram uma predominância de estrutura $\alpha$-hélice na amostra nativa, na qual se espera a crotoxina intacta quanto à sua estrutura. Após irradiação, e a possível separação das subunidades, a estrutura a-hélice tem a contribuição diminuída. Se os valores das subunidades mostrados na Tabela 9 para a estrutura $\alpha$-hélice forem somados, totalizarão $21 \%$, valor menor do que aquele observado para a crotoxina (37,5\%). A mesma relação pode ser 
extrapolada para a estrutura folha $\beta$, uma vez que a somatória dos valores para as subunidades totalizam $79,5 \%$, porcentagem maior do que aquela observada para a crotoxina nativa (45\%). Aird e cols. (1989) também sugerem que as subunidades apresentaram diminuição significativa em a-hélice quando estudadas isoladamente, enquanto ocorreu um aumento de folha $\beta$ em relação à toxina intacta. Assim, é possível que a estrutura de $\alpha$-hélice participe das interações entre crotapotina e PLA $\mathrm{P}_{2}$, e a consequente separação destas subunidades após o processo de irradiação pode gerar a diminuição desta forma estrutural.

Segundo o Protein Data Bank (PDB), a isoforma CB2 da crotoxina apresenta $50 \%$ de a-hélice com 62 resíduos formando 8 hélices, enquanto a estrutura folha $\beta$ representa apenas $9 \%$ da conformação total. Em relação à isoforma CB1, 45\% da estrutura secundária é composta por $\alpha$-hélice e apenas 3\% de folha $\beta$. Assim, a existência de isoformas da crotoxina e o fato de que estas isoformas coexistem, muitas vezes, no veneno de uma única serpente, pode dificultar a determinação da estrutura secundária considerando que neste estudo não foi realizado o isolamento de uma isoforma específica.

Cabe ressaltar que os dados referentes à estrutura folha $\beta$ em CD podem apresentar maiores imprecisões devido à natureza das ligações nesta estrutura.

Na Figura 26 observou-se o perfil espectrométrico da crotamina nativa e irradiada quando submetidas à análise por CD. Foi possível observar alterações na estrutura secundária da proteína após irradiação, principalmente na região de transição de folha $\beta$ (195 e $200 \mathrm{~nm}$ e $216 \mathrm{~nm}$ ). A primeira região de transição da estrutura $\alpha$-hélice ( 191 - 193 nm) não apresentou alterações significativas. Em $222 \mathrm{~nm}$ observou-se que a curva da crotamina irradiada encontra-se em uma região inferior quando comparada com a toxina nativa, porém, não foi observada a banda negativa intensa característica da região de $222 \mathrm{~nm}$. A região de 208 $210 \mathrm{~nm}$ apresentou maior relevância quanto às modificações observadas anteriormente. Dados na literatura sugerem que a estrutura secundária de folha $\beta$ é predominante na molécula de crotamina. Por meio de modelagem computacional, Siqueira e cols. (2002) propuseram uma estrutura estável da molécula de crotamina, composta por 2 folhas $\beta$ e regiões aleatórias. Nicastro e cols. (2003) apresentaram uma estrutura tridimensional resolvida por ${ }^{1} \mathrm{H}-\mathrm{RMN}$ 
composta por 3 segmentos de folha $\beta$ e o $\mathrm{N}$ terminal estruturado como $\alpha$-hélice, interligados por estrutura aleatória. Fadel (2005), utilizando a técnica de RMN apresentou resultados coincidentes com a estrutura proposta por Nicastro e cols. (2003). Possivelmente, após irradiação, a proteína perdeu parte da estrutura conformacional nativa, apresentando um aumento da configuração randômica, ou regiões aleatórias. Estes dados corroboram os relatos de Boni-Mitake (2001) que mostrou por meio do espectro de CD da crotamina que o fato de não aparecerem bandas características de $\alpha$-hélice não excluem a sua formação, sugerindo apenas que a crotamina nativa não possui quantidades significativas de $\alpha$-hélice. Ainda segundo Boni-Mitake (2001), a negatividade observada no espectro da crotamina irradiada pode sugerir desnaturação protéica. Casare (2009) também observou grandes alterações na estrutura da crotamina irradiada em comparação à toxina nativa.

A espectroscopia de Infravermelho (IR) é uma técnica extremamente antiga e bem estabelecida na análise da estrutura secundária de peptídeos e proteínas. O desenvolvimento do método Transformada de Fourier (FTIR) ampliou a aquisição de dados no IR, cujo sinal medido resulta da intensidade de absorção da radiação $I R$ pela amostra. As medidas espectrais são usualmente interpretadas em termos de vibrações de unidades estruturais repetidas (Kong \& Yu, 2007). Há nove bandas características de vibração em FTIR, sendo que algumas regiões do espectro são mais sensíveis, resultando em bandas vibracionais de maior proeminência. Estas regiões são denominadas bandas de amida I e II. Destas, a banda da amida I (1700-1600 $\left.\mathrm{cm}^{-1}\right)$, que é praticamente toda representada por ligações do tipo $\mathrm{C}=\mathrm{O}$ (aproximadamente $80 \%$ ), é ainda mais sensível. Dessa maneira, a alta sensibilidade a pequenas variações na geometria molecular fazem a banda da amida I extremamente usual para a análise da composição estrutural e mudanças conformacionais na estrutura secundária das proteínas. Estritamente falando, o contorno observado na banda da amida I de proteínas e peptídeos consiste da sobreposição de componentes de bandas, representando $\alpha$-hélice, folha $\beta$, turns e estrutura randômica. Assim, por meio de análises matemáticas, tem-se que a banda da amida I é formada por picos individuais localizados a uma determinada frequência: os picos 1688, 1678, 1674 e $1667 \mathrm{~cm}^{-1}$ representam estruturas $\beta$-turn; $1657 \mathrm{~cm}^{-1}$ foi relatado a $\alpha$-hélice; 
1650 e $1644 \mathrm{~cm}^{-1}$ é representativo de estrutura randômica; e os picos em 1633 e $1621 \mathrm{~cm}^{-1}$ correspondem à folha $\beta$ (Cui e cols., 2001).

Outra técnica associada ao sistema de FTIR é a Reflectância Total Atenuada (Attenuated Total Reflectance - ATR). O acessório de ATR opera medindo as mudanças que ocorrem no feixe infravermelho quando este incide na amostra e ao atravessá-la, é internamente refletido. Os dados obtidos em análises de ATR e os de FTIR não apresentam diferenças relevantes como mostraram Goormaghtigh e cols. (2009) com o estudo comparativo entre as técnicas de 45 proteínas. Assim, considerando os estudos promissores que reportam o potencial da espectroscopia IR, destaca-se a versatilidade e agilidade nos resultados, que podem proporcionar rápidas análises em relação aos métodos tradicionais. A técnica de ATR foi a escolhida para a análise da estrutura secundária da crotoxina e da crotamina neste trabalho.

Nas Figuras 27 e $\mathbf{2 8}$ foram apresentados os espectros da crotoxina e crotamina, respectivamente, comparando-se os dados espectrais obtidos, nos dois casos, tanto para a toxina nativa, como para a irradiada. Em ambas as figuras verificou-se que a curva da amostra nativa difere substancialmente daquela observada para a amostra irradiada, sendo tal discrepância extremamente significante na região espectral da banda da amida I. Foi possível observar ainda que a região entre 3500 e $3200 \mathrm{~cm}^{-1}$ também se destacou com relação à diferença espectral na curva das amostras nativa e irradiada. Embora tal intervalo não seja significativo no estudo da estrutura secundária, é importante considerar que a região de $\sim 3500 \mathrm{~cm}^{-1}$ corresponde à ligações $\mathrm{O}-\mathrm{H}$ de grupos hidroxil e a região de $\sim 3200 \mathrm{~cm}^{-1}$ corresponde à ligações $\mathrm{N}-\mathrm{H}$ do grupamento amida (Beekes e cols., 2007). Todas as proteínas que compõem os organismos são constituídas por sequências de aminoácidos, ligados covalentemente. Estes compostos possuem grupos $-\mathrm{OH}$ e - $\mathrm{NH}$ capazes de formar uma forte rede de ligações intermoleculares. É isto que origina a estrutura terciária das proteínas, isto é, a sua forma característica de orientação espacial. Assim, os espectros de ATR-FTIR sugerem que a estrutura terciária da crotoxina e crotamina sofreram alterações, uma vez que se verificou uma menor absorbância na curva das amostras irradiadas em relação às toxinas nativas. 
Em virtude da importância da região da banda da amida I, esta área foi amplificada gerando-se um espectro mais detalhado em relação à curva obtida na banda da amida I (Figuras 29 e 30). Foi possível observar que os espectros da crotoxina e crotamina, antes da irradiação, mostraram uma curva com suaves picos ao longo da região da amida I, sendo que para a crotoxina, as vibrações internas mostraram-se mais proeminentes do que em relação à crotamina. Após a irradiação, houve o surgimento de picos bem definidos, antes não identificados, tanto na curva da crotoxina como na da crotamina. Possivelmente estes picos existiam no espectro, porém apareciam de forma discreta. Observou-se também que a curva da crotamina irradiada foi deslocada em aproximadamente $20 \mathrm{~cm}^{-1}$ para a esquerda. O deslocamento ficou mais evidente para a crotamina, o que pode sugerir uma menor estabilidade desta proteína quando comparada à crotoxina. Em vista da ação da radiação quanto à ionização da molécula e de sua capacidade em modificar a estrutura protéica, estes fenômenos podem estar associados a uma forte interação da proteína com produtos de menor massa molecular, resultantes de quebras, podendo evidenciar inclusive, a formação de peptídeos, aminoácidos ou até de agregados protéicos (Nascimento, 1995; Cui e cols., 2001). A presença destes vizinhos moleculares pode modificar a sinergia entre os grupos peptídicos, modificando a energia total da molécula.

Nas Figuras 31 e 32, o espectro da segunda derivada da banda da amida I foi apresentado, para a crotoxina e crotamina, respectivamente. Esta é uma análise usual na interpretação dos dados de FTIR. Mais uma vez os espectros comprovam a diferença entre as curvas referentes às amostras nativas e irradiadas.

Como já mencionado anteriormente, segundo o PDB, as isoformas CB1 e CB2 da crotoxina apresentam, respectivamente, 45 e $50 \%$ de estrutura $\alpha$ hélice, contra apenas 3 e $9 \%$ de folha $\beta$, mostrando a predominância da primeira. No histograma apresentado na Figura 33, observou-se que a estrutura a-hélice $(45,2 \%)$ prevalece em relação às demais. Além disso, também se verificou a presença em grande parte de $\beta$-turns (35,5\%). Após a irradiação ocorreu um grande aumento da folha $\beta$ (de 9,7\% para 42,85\%) e uma consequente diminuição de $\alpha$-hélice $(10,7 \%)$, sendo que a estrutura randômica e $\beta$-turns não tiveram variação significativa. É interessante notar que praticamente a mesma 
quantidade (em termos de porcentagem) da estrutura $\alpha$-hélice que diminuiu, aumentou em termos da estrutura folha $\beta$. Cabe dizer também, que as quantidades estruturais obtidas por ATR-FTIR para a crotoxina, estão bem próximas dos valores apresentados por Hanley (1979), Aird e cols. (1989) e pelo banco de dados (PDB).

Foi possível observar na Figura 34, que, inicialmente, a crotamina apresentou somente estrutura folha $\beta$ e aparentemente não foram identificadas outras estruturas. Isto se deve, em parte, pelo fato da técnica de ATR-FTIR não se mostrar suficientemente sensível para detectar a concentração das outras vibrações correspondentes à estrutura randômica, $\beta$-turns e $\alpha$-hélice, em amostras liofilizadas. Após a irradiação, porém, a crotamina apresentou um aumento das bandas de estrutura randômica $(21,4 \%), \beta$-turns $(28,6 \%)$ e $\alpha$-hélice $(21,4 \%)$ e uma brusca diminuição da folha $\beta$, chegando a $28,6 \%$.

A Tabela 10 resume os valores encontrados nas análises de CD e ATR-FTIR para estrutura secundária da crotoxina e crotamina nos estados nativo e irradiado. É possível observar que os valores encontrados não são exatamente os mesmos nas duas metodologias e em alguns casos não são nem próximos. Dentre outros motivos, cabe ressaltar que tal fato pode ser parcialmente explicado pela sensibilidade das técnicas, uma vez que o CD é mais sensível à detecção de a-hélice e a técnica de ATR-FTIR apresenta maior sensibilidade para estrutura do tipo folha $\beta$.

Tabela 10: Estrutura secundária da crotoxina e crotamina a partir das técnicas de CD e ATR-FTIR.

\begin{tabular}{lccccccc}
\hline & & \multicolumn{3}{c}{ Dicroísmo Circular* } & \multicolumn{3}{c}{ ATR-FTIR } \\
& & $\alpha$-hélice & $\boldsymbol{\beta}$-turn & folha $\boldsymbol{\beta}$ & $\boldsymbol{\alpha}$-hélice & $\boldsymbol{\beta}$-turn & folha $\boldsymbol{\beta}$ \\
\hline \multirow{2}{*}{ Crotoxina } & Nativa & $99,9 \%$ & $2,1 \%$ & $0,0 \%$ & $45,2 \%$ & $35,5 \%$ & $9,7 \%$ \\
& & & & & & & \\
& Irradiada & $98,2 \%$ & $5,2 \%$ & $1,1 \%$ & $10,7 \%$ & $32,2 \%$ & $42,8 \%$ \\
\hline \multirow{2}{*}{ Crotamina } & Nativa & $15,6 \%$ & $20,5 \%$ & $41,3 \%$ & $0,0 \%$ & $0,0 \%$ & $100 \%$ \\
& & & & & & & \\
& Irradiada & $20,0 \%$ & $19,6 \%$ & $32,9 \%$ & $21,4 \%$ & $28,6 \%$ & $28,6 \%$ \\
\hline
\end{tabular}


No caso da crotoxina, foi possível observar por meio das duas técnicas, o predomínio da estrutura a-hélice. Os dados de CD mostraram-se mais extremos, com quase $100 \%$ desta forma estrutural e $0,0 \%$ de folha $\beta$. A análise de ATR-FTIR também indicou uma baixa porcentagem para folha $\beta$ e o maior valor para $\alpha$-hélice, considerando a toxina nativa. Para a crotoxina irradiada, os dados de ATR-FTIR foram mais relevantes quanto a alterações da estrutura secundária.

Para a crotamina, observou-se o predomínio de folha $\beta$, sendo que neste caso, os dados de ATR-FTIR mostraram-se mais extremos. Por meio das duas metodologias foi possível observar o aumento de $\alpha$-hélice e a diminuição de folha $\beta$.

A baixa resolução dos resultados obtidos nas técnicas de CD e ATRFTIR claramente não promovem uma informação estrutural detalhada, como é observado, por exemplo, em técnicas cristalográficas, metodologia na qual a formação do cristal referente à proteína irradiada seria praticamente impossível devido, dentre outros fatores, a perda da estabilidade conformacional. Entretanto, eles podem ajudar a construir o espaço existente entre a sequência de aminoácidos e a função da proteína, uma vez que promovem indícios sobre a conformação estrutural que a proteína pode adotar. Em adição, muitas destas técnicas são rápidas e requerem uma pequena quantidade de amostra, fatores de grande importância em diversos casos.

É cada vez mais aparente que informações termodinâmicas, bem como relatos estruturais são requeridos para o desenvolvimento de uma consistente inter-relação entre funções estruturais, energéticas e biológicas. Em reconhecimento a este fato, é observado um considerável aumento em estudos voltados a caracterização termodinâmica de um grande número de moléculas biológicas (Plum \& Breslauer, 1995).

Frequentes desenvolvimentos em microeletrônica e na instrumentação tem permitido o estudo calorimétrico de macromoléculas biológicas em concentrações razoáveis. Tal fato representava uma limitação em análises termodinâmicas, já que concentrações exorbitantes se faziam necessárias. Em decorrência desses avanços é possível atualmente caracterizar termodinamicamente transições de ordem-desordem, também chamadas de 
melting, bem como eventos de ligações entre macromoléculas ou entres estas e outro ligante.

Transições de ordem-desordem induzidas termicamente têm sido estudadas principalmente por Calorimetria Diferencial (Differential Scanning Calorimetry - DSC).

Quanto à calorimetria, usualmente o perfil calorimétrico mostra um pico de transição que é atribuído à absorção de calor associada à desnaturação da proteína, enquanto que os valores de pré e pós-transição refletem a capacidade calorífera parcial $\left(C_{p}^{e x}\right)$ dos estados nativo e desnaturado da proteína, respectivamente (Privalov e cols., 1974; Krishnan \& Brandts, 1978; Privalov, 1980). A integral de $C_{p}^{e x}$ em relação à temperatura $(T)$ fornece a entalpia de transição, $\Delta H$.

Na Figura 35, perfil calorimétrico da crotoxina, observou-se relevante diferença entre a amostra nativa (perfil A) e a amostra irradiada (perfil B). No perfil da crotoxina nativa, a primeira transição térmica ocorreu à temperatura de aproximadamente $43 \stackrel{\circ}{\circ}$. Esta transição foi formada por um pico de entalpia positiva, seguido de um pico de entalpia negativa (melting). A cerca de $59{ }^{\circ} \mathrm{C}$ uma transição mais intensa em termos energéticos foi observada, segundo o mesmo perfil de transição (pico positivo seguido de pico negativo). O último pico significativo foi a aproximadamente $72^{\circ} \mathrm{C}$, o que sugere que a crotoxina, após esta temperatura, apresentou-se totalmente desnaturada. No perfil da crotoxina irradiada as principais transições ocorreram entre 33 e $41^{\circ} \mathrm{C}$, sendo que após esta temperatura não foi observado mais nenhum pico significativo, sugerindo então a completa desnaturação protéica.

Estes resultados mostraram que a toxina irradiada atinge o estado desnaturado a uma temperatura menor do que aquela necessária para a desnaturação da toxina nativa.

Sturtevant e cols. (1994) enfatizaram que, possivelmente, pequenas alterações estruturais significam grandes impactos energéticos nas proteínas. Ladbury e cols. (1994) examinaram os efeitos termodinâmicos da redução de pontes dissulfeto na ausência de mudança conformacional significativa na proteína por comparação de formas oxidadas e reduzidas de E.Coli (thioredoxina) 
e revelaram que a forma reduzida mostrou-se desestabilizada em relação à forma oxidada. Thomson e cols. (1994) mostraram que a comparação termodinâmica da alteração de um aminoácido pode significar diferentes valores de entalpia e capacidade térmica.

Dados muito semelhantes foram obtidos para a crotamina (Figura 36). Portanto o perfil calorimétrico da crotamina nas formas nativa e irradiada permitiu inferir que a energia na forma de calor requerida na desnaturação protéica da amostra nativa foi consideravelmente maior quando comparada à amostra irradiada. Assim, para uma total desnaturação da crotamina irradiada, cujo perfil calorimétrico se mostrou muito mais irregular em relação ao perfil da crotamina nativa, foi necessário um aquecimento de aproximadamente $27^{\circ} \mathrm{C}$. Por outro lado, o aquecimento da toxina no seu estado nativo chegou a cerca de $46{ }^{\circ} \mathrm{C}$. Pode-se dizer então que a estabilidade estrutural foi significativamente afetada pelo processo de irradiação.

Assim, fica evidente que a radiação alterou a conformação protéica, tanto da crotoxina como da crotamina, gerando uma instabilidade energética (estado conformacional de menor entalpia) nas toxinas, o que, consequentemente favoreceu a sua desnaturação a menores temperaturas. A despeito das evidências de tais alterações, ainda são necessários estudos que ajudem a entender as alterações na estabilidade conformacional das proteínas de uma forma geral. Todas as análises estruturais e de estabilidade energética apresentadas neste trabalho sugerem significativas alterações nas toxinas irradiadas quando comparadas com os dados obtidos das amostras no estado nativo.

Portanto, de acordo com o apresentado neste trabalho, fica claro que a radiação ionizante promove alterações conformacionais, observadas nas estruturas secundária e terciária da crotamina e da crotoxina, o que possivelmente leva a perda da estabilidade protéica no dois casos. Tais observações podem explicar as mudanças quanto à atividade biológica destas toxinas. 


\section{CONCLUSÕES}

> As toxinas do veneno da C.d.terrificus, crotoxina e crotamina, foram efetivamente isoladas por meio de técnicas cromatográficas;

A estrutura secundária e a estrutura terciária, tanto da crotoxina como da crotamina, foram modificadas após irradiação com 2 kGy;

A análise das toxinas por Fluorescência permitiu avaliar mudanças estruturais frente à exposição do resíduo de triptofano, considerando que a crotamina apresentou um quenching de fluorescência, e a crotoxina um descolamento do perfil;

A técnica de Dicroísmo Circular permitiu identificar alterações na estrutura secundária da crotamina e da crotoxina, sendo que tanto a região da estrutura de folha $\beta$, como a estrutura de $\alpha$-hélice apresentaram-se em quantidades modificadas na toxina nativa e após irradiação;

A partir da técnica de ATR-FTIR foi possível ratificar as alterações na estrutura secundária da crotoxina e da crotamina, previamente observadas por CD, principalmente na região da banda da amida I;

$>$ O perfil obtido por Calorimetria Diferencial mostrou a perda da estabilidade conformacional das toxinas na forma irradiada, uma vez que após irradiação, tanto a crotoxina como a crotamina foram desnaturadas a uma temperatura inferior àquela necessária para desnaturar as toxinas no estado nativo;

As análises estruturais realizadas neste trabalho permitiram observar alterações na estrutura conformacional da crotoxina e da crotamina após o processo de irradiação destas toxinas. 


\section{REFERÊNCIAS BIBLIOGRÁFICAS}

AIRD, S.D.; KAISER, I.I.; LEWIS, R.V.; KRUGGEL, W.G. Rattlesnake presynaptic neurotoxins: primary structure and evolutionary origin of the acid subunit. Biochem., v. 24 (25), p. 7054-7058, 1985.

AIRD, S.D.; STEADMAN, B.L.; MIDDAUGH, C.R.; KAISER, I.I. Comparative spectroscopic studies of four crotoxin homologs and their subunits. Biochem. Biophys. Acta, v. 997, p. 211-218, 1989.

ALEXANDER, G.; GROTHUSEN, J.; ZEPEDA, H.; SCHWARTZMAN, R. Giroxin, a toxin from the venom of Crotalus durissus terrificus is thrombin like enzyme. Toxicon, v. 26 (10), p. 953-960, 1988.

ANDRIANI, E.P. Irradiação da crotoxina em solução aquosa: influência das principais espécies reativas nas alterações estruturais, biológicas e imunológicas. 1995. Dissertação (Mestrado) - Instituto de Pesquisas Energéticas e Nucleares, São Paulo.

ARNI, R.K.; WARD, R.J.; GUTIERREZ, J.M.; TULINSKY, A. Structure of a calciumindependent phospholipase-like myotoxic protein from Bothrops asper venom. Acta Cryst. Biol. Crystallogr., v. 51, p. 311-317, 1995. Section D.

ARTEAGA, M.A. Unión Neuromuscular Y Relajantes Musculares. 2003. Disponível em:<www.anestesianet.com/unal/rnm.htm>. Acesso em: 08 set. 2009.

ATKINS, P.W. Physical Chemistry. 6a Edition.Oxford University Press, 1998

AZEVEDO-MARQUES, M.M.; HERING, S.E.; CUPO, P. Evidence that Crotalus durissus terrificus (South American rattlesnake) envenomation in humans causes myolisis rather than hemolysis. Toxicon, v. 25, p. 1163-1168, 1987.

BAPTISTA, J.A. Aspectos da resposta imune frente a antígenos protéicos irradiados com Co-60. 2004. Dissertação (Mestrado) - Instituto de Pesquisas Energéticas e Nucleares, São Paulo.

BAPTISTA, J.A. Resposta imune frente à Bothropstoxina-1 irradiada com ${ }^{60} \mathrm{Co:}$ identificação das principais citocinas envolvidas e a participação de substâncias scavengers. 2009. Tese (Doutorado) - Instituto de Pesquisas Energéticas e Nucleares, São Paulo.

BASTOS, C.A. Otimização de Metodologia por Cromatografia Líquida em Fase Reversa por Pareamento lônico para Análise Simultânea de Paracetamol, Cloridrato de Fenilefrina e Maleato de Carbinoxamina em Formulações Farmacêuticas. 2008. Dissertação (Mestrado) - Universidade Federal de Juiz de Fora, Minas Gerais.

BEEKES, M.; LASCH, P.; NAUMANN, D. Analytical applications of Fourier transforminfrared (FT-IR) spectroscopy in microbiology and prion research. Vet. Microbiol., v. 123(4), p. 305-319, 2007.

BELTRAN, J.R.; MASCARENHAS, Y.P. SAXS study of structure and conformation changes of crotamine. Biophys. J., v. 47, p. 33-35, 1985. 
BELTRAN, J.R.; MASCARENHAS, Y.P. SAXS study of the snake toxin a-crotamine. Eur. Biophys., v. 17, p. 325-329, 1990.

BERLETT, B.S. \& STADTMAN, E. R. Protein oxidation in aging, disease and oxidative stress. J. Biol. Chem., v, 272(33), p. 20313-20316, 1997.

BICALHO, R.X.; ROCHA, O.A.; HENEINE, L.G.D.; MAGALHÃES, A.; HENEINE, I.F. The effect of stepwise iodination on biological properties of Bothrops jararaca venom. Toxicon, v. 28(2), p. 171-179, 1990.

BJARNASON, J.B. \& FOX, J.W. Hemorrhagic toxins from snake venom. J. Toxicol. Toxin Rev., v. 7, p. 121-209, 1988.

BOBER, M.A.; GLENN, J.L.; STRAIGHT, R.C.; OWNBY, C.L. Detection of myotoxin a-like proteins in various snake venoms. Toxicon, v. 26, p. 665-673, 1988.

BOCHNER, R. \& STRUCHINER, C.J. Acidentes por animais peçonhentos e sistemas nacionais de informação. Cadernos de Saúde Pública, v. 18, p. 735-746, 2002.

BOCHNER, R. \& STRUCHINER, C.J. Epidemiologia dos acidentes ofídicos nos últimos 100 anos no Brasil: uma revisão. Cadernos de Saúde Pública, v. 19, p. 7-16, 2003.

BOHM, G.; MUHR, R.; JAENICKE, R. Quantitative analysis of protein far UV circular dichroism spectra by neural networks. Protein Engineering, v. 5, p. 191-95, 1992.

BON, C. Snake venom \& pharmacopeia. 1994. In: Bauchot, R. (Ed.). Snakes: a natural history. Sterling Publishing Company, Inc., New York, p.194-203.

BON, C.; CHANGEUX, J.F.; JENG, T.W.; FRAENKEL-CONRAT, H. Postsynaptic effects of crotoxin and its isolated subunits. Eur. J. Biochem., v. 99, p. 471-81, 1979.

BONI-MITAKE, M.; COSTA, H.; SPENCER, P.J.; VASSILIEFF, V.S.; ROGERO, J.R. Effects of ${ }^{60} \mathrm{Co}$ gamma radiation on crotamine. Brazil. J. Med. Biol. Research., v. 34, p. $1531-1538,2001$.

BONI-MITAKE, M. Estudos Bioquímicos e Farmacológicos das Crotaminas Nativa e Irradiada com Radiação Gama de ${ }^{60}$ Co. 2000. Tese (Doutorado) - Instituto de Pesquisas Energéticas e Nucleares, São Paulo

BOUCHIER, C.; BOULAIN, J.C.; BON, C.; MÈNEZ, A. Analysis of cDNAs encoding the two subunits of crotoxin, a phospholipase $A 2$ neurotoxin from rattlesnake venom: the acid non-enzymatic subunits derives from a phospholipase A2-like precursor. Biochem. Biophys. Acta, v. 1088, p. 401-408, 1991.

BREITHAUPT, H. Neurotoxic and myotoxic effects of crotalus phospholipase A and its complex with crotapotin. N-S Arch Pharmacol., v. 292(3), p. 271-278, 1976.

BREITHAUPT, H.; RUBSAMEN, K.; HABERMANN, E. Biochemistry and pharmacology of the crotoxin complex. Eur. J. Biochem., v. 49, p. 333-345, 1974.

BROWN, R.S.; BROWN, M.B.; BDOLAH, A.; KOCHVA, E. Accumulation of some secretory enzymes in venom glands of Vipera palaestinae. Amer. J. Physiol., v. 229, p. 1675-1679, 1975. 
BUTLER, J.; HOEY, B.M.; SWALLOW, A.J. Radiation chemistry. Annu. Rep. Prog. Chem., v. 83, p. 129-175, 1987.

BUTLER, J.; LAND E.J.; SWALLOW A.J. Chemical mechanisms of the effects of high energy radiation on biological systems. Radiat. Phys. Chem., v. 24, p. 273-282, 1984.

CALMETTE, A. Les animaux nenimeux et la sérotherapie antivenimeuse. In: Les Venins. Masson et Cie, Paris, 1907.

CAMPOS, L.A. Isolamento e caracterização da delta-toxina do veneno de Crotalus durissus terrificus. 2006. Dissertação (Mestrado) - Instituto de Pesquisas Energéticas e Nucleares, São Paulo.

CAPRONI, P. Ação da Bothropstoxina-1 e do veneno total de Bothrops jararacussu irradiados sobre o sistema imune. 2009. Dissertação (Mestrado) - Instituto de Pesquisas Energéticas e Nucleares, São Paulo.

CARDI, B.A.; NASCIMENTO, N.; ROGERO, J.R.; ANDRADE, H.F. Immunochemical detection of purified crotoxin from Crotalus durissus terrificus venom in motor end plate of striated muscle in CBA/J mice. Braz. J. Med. Biol. Res., v. 25, p. 905, 1992.

CARDOSO, J.L.C.; FRANCA, F.O.S.; WEN, F.H. Acidente botrópico. 2003. In: Animais peçonhentos no Brasil: biologia, clínica e terapêutica dos acidentes. França, F.O.S. \& Málaque, C.M.S. (Eds.). Editora Sarvier, São Paulo, p. 72-86.

CARDOSO, J.L.C.; FRANCA, F.O.S.; WEN, F.H. Introdução ao ofidismo. 2003. In: Animais Peçonhentos no Brasil: Biologia, Clínica e Terapêutica dos Acidentes. Araújo, F.A.A.; Santalúcia, M.; Cabral, R.F. (Eds.). Editora Sarvier, São Paulo, p. 6-12.

CASARE, M.S. Estudo das interações dos produtos de radiólise da água com a miotoxina do veneo de Crotalus durissus terrificus. 2009. Tese (Doutorado) Instituto de Pesquisas Energéticas e Nucleares, São Paulo.

CASARE, M.S. Influência das principais espécies reativas formadas durante 0 processo de destoxicação de toxinas por radiação ionizante. 2003. Dissertação (Mestrado) - Instituto de Pesquisas Energéticas e Nucleares, São Paulo.

CECCHINI, A.L.; SOARES, A.M.; CECCHINI, R.; DE OLIVEIRA, A.H.; WARD, R.J.; GIGLIO, J.R.; ARANTES, E.C. Effect of crotapotin on the biological activity of Asp49 and Lys 49 phospholipases $A_{2}$ from Bothrops snake venoms. Comp. Biochem. Physiol., v. 138C, p. 429-436, 2004.

CHANG, C.C. \& TSENG, K.H. Effects of crotamine, a toxin of South American rattlesnake venom, on the sodium channel of murine skeletal muscle. Br. J. Pharmacol., v. 63(3), p. $551-559,1978$.

CHANG, C.C. Neurotoxins with phospholipase A2 activity in snake venoms. Proc. Natn. Sci. Council. R.O.C. B9: 126-42, 1985.

CHANG, C.C.; LEE, D. Crotoxin, the neurotoxin of South American rattlesnake venom, is a presynaptic toxin acting like $\beta$-bungarotoxin. N-S Arch. Pharmacol., v. 296, p.159-168, 1977. 
CHEN, R.F.; EDELHOCH, H.; STEINER, R.F. Physical Principles and Techniques of Protein Chemistry, Part A. 1969. Leach, S.J. (Ed.), Academic Press: New York, p. 171244.

CHEN, Y.; BARKLEY, M.D. Toward understanding tryptophan fluorescence in proteins. Biochem., v. 37(28), p. 9976-9982, 1998.

CHEYMOL, J.; GONÇALVES, J.M.; BOURILLET, F.; ROCH-ARVEILLER, M. Action neuromusculaire compare de la crotamine et du venin de Crotalus durissus terrificus var. Crotaminicus I. Sur preparations neurimusculaires in situ. Toxicon, v. 9, p. 279-286, 1971.

CLISSA, P. B. Otimização da atenuação da toxicidade do veneno crotálico irradiado e estudo de suas propriedades imunológicas. 1997. Dissertação (Mestrado) - Instituto de Pesquisas Energéticas e Nucleares, São Paulo.

COSTA, L.M.; TAKEDA, A.K., BARBOSA, S.F.C.; BERRA, J.A.P.; ADELINA, M.G.F.; SOERENSEN, B.; PINTO, J.R.; VANCETTO, M.D.C. Estudo comparativo da resposta imune em cavalos ao veneno de Crotalus durisssus terrificus in natura, tratado com formaldeído e submetido a ação térmica. Vacinas e Soros, v. 1, p. 24-29, 1985.

CRABBÉ, P. ORD and CD in Chemistry and Biochemistry, Academic Press: New York. 1972.

CUI, F.Z.; LIN, Y.B.; ZHANG,D.M.; TIAN, M.B. Irradiation effects on secondary structure of protein induced by keV ions. Radiat. Phys. Chem., v. 60, p. 35-38, 2001.

DANIEL, J.P.; HENEINE, L.D.G.; TAVARES, C.A.P.; NASCIMENTO, M.C.S.; HENEINE, I.F. Generation of protective immune sera by C.d.terrificus venom detoxified by controlled iodination. Braz. J. Med. Biol. Res., v. 20, p. 713-720, 1987.

DAVIES, K.J.A. Protein damage and degradation by oxygen radicals. I general aspects. J. Biol. Chem., v. 262, p. 9895-9901, 1987.

DE LUCCA, F.L.; HADDAD, A.; KOCHVA, E.; ROTHSCHILD, A.M.; VALERI, V. Protein synthesis and morphological changes in the secretory epithelium of the venom gland of Crotalus durissus terrificus at different times after manual extraction of venom. Toxicon, v. 12, p. 361-368, 1974.

DEGANI, A.L.G.; QUEZIA, B.C.; VIEIRA, P.C. Cromatografia - Um breve ensaio. Química Nova na Escola, v. 7, p. 21-25, 1998.

DEVI, A. The chemistry, toxicity, biochemistry and pharmacology of North American snake venoms. In: Büchler, W. \& Buckley, E. (Ed.). Venomous Animals and Their Venoms, v. II, Academic Press: New York p. 175-202, 1971.

DOLEY, R. \& KINI, R.M. Protein complexes in snake venom. Cell. Mol. Life Sci., v. 66, p. 2851-2871, 2009.

DOS SANTOS, M.C.; MORHY, L.; FERREIRA, L.C.L.; OLIVEIRA, E.B. Purification and properties of a crotamine analog from Crotalus durissus terrificus venom. Toxicon, v. $31(2)$, p. 166, 1993. 
ENDO, T.; OYA, M.; OZAWA, H.; KAWANO, Y.; GIGLIO, J.R.; MIYAZAWA, T. A proton nuclear magnetic resonance study on the solution structure of crotamine. J. Protein. Chem., v. 8, p. 807-815, 1989.

ENGLE, C.M.; BECKER, R.R.; BAILEY, T. Characterization of two myotoxic proteins from venom of Crotalus viridis concolor. J. Toxicol., v. 2, p. 267-283, 1983.

EXPASY - UniProtKB: banco de dados. Disponível em:<http://www.uniprot.org/uniprot>. Acesso em: 20 set. 2009.

FADEL, V.; BETTENDORFF, P.; HERMANN, T.; AZEVEDO JR., W.F.; OLIVEIRA, E.B.; YAMANE, T.; WÜTHRICH, K. Automated NMR structure determination of the myotoxin crotamine from Crotalus durissus terrificus. Toxicon, v. 49, p. 759-767, 2005.

FAURE, G. \& BON, C. Crotoxin, a phospholipase A2 neurotoxin from the South American rattlesnake Crotalus durissus terrificus. Purification of several isoforms and comparision of their molecular structure and their biological activities. Biochem., v. 27, p. 730-738, 1988.

FAURE, G. \& BON, C. Several isoforms of crotoxin are present in individual venoms from the South American Rattlesnake Crotalus durissus terrificus. Toxicon, v. 25, p. 229-234, 1987.

FAURE, G.; CHOUMET, V.; BOUCHIER, C.; CAMOIN, L.; GUILLAUME, J.L.; MONEGIER, B.; VUILHORGNE, M.; BON, C. The origin of the diversity of crotoxin isoforms in the venom of Crotalus durissus terrificus. Eur. J. Biochem., v. 223, p. 161164, 1994.

FAURE, G.; HARVEY, A.L.; THOMSON, E.; SALIOU, B.; RADVANYI, F.; BON, C. Comparison of crotoxin isoforms reveals that stability of the complex plays a major role in its pharmacological action. Eur. J. Biochem., v. 214, p. 491-496, 1993.

FLETCHER, J.E.; HUBERT, M.; WIELAND, S.J.; GONG, Q.H.; JIANG, M.S. Similarities and differences in mechanisms of cardiotoxins and other myotoxins. Toxicon, v. 34, p. 1301-1311, 1996.

FLOWERS, H.H. The effects of X-irradiation on the biological activity of cottonmouth moccasin (Ancistrodon piscivorus) venom. Toxicon, v. 1, p. 131-136, 1963.

FOX, J.W.; ELZINGA, M.; TU, A.T. Amino acid sequence and disulfide bond assignment of myotoxin a isolated from the of prairie rattlesnake (Crotalus viridis viridis). Biochem., $v$. 18, p. 678-684, 1979.

GALLACCI, M.; NASCIMENTO, N.; ROGERO, J.R.; VASSILIEFF, V.S. Influence of temperature upon effects of crotoxin and gamma-irradiated crotoxin at rat neuromuscular transmission. Toxicol. Lett., v. 114, p. 77-80, 2000.

GARRISON, W.M. Reaction mechanisms in the radiolysis of peptides, polypeptides, and proteins. Chem. Rev., v. 87, p. 381-398, 1987.

GONÇALVES, J.M. \& ARANTES, E.G. Estudos sobre venenos de serpentes brasileiras. III - Determinação quantitativa de crotamina no veneno de cascavel brasileira. An. Acad.

Bras. Cienc., v. 28, p. 369-371, 1956. 
GONÇALVES, J.M. \& VIEIRA, L.G. Estudos sobre venenos de serpentes brasileiras. I Análise eletroforética. An. Acad. Bras. Cienc., v. 22, p. 141-149, 1950.

GONÇALVES, J.M. Estudos sobre venenos de serpentes brasileiras. II - Crotalus terrificus crotsminicus, suespécie biológica. An. Acad. Bras. Cienc., v. 28, p. 365-367, 1956.

GOOMAGHTIGH, E.; RÉGIS, G.; AUDREY, B.; ANDRÉA, G.; VINCENT, R. Protein secondary structure content in solution, films and tissues: Redundancy and complementary of the information content in circular dichroism, transmission and ATR FTIR spectra. Biochim. Biophys. Acta, v. 1794, p. 1332-1343, (2009).

GRASSET, E. Anavenoms and their use in the preparation of antivenoms sera. Trans. R. Soc. Trop. Med. Hyg., v. 38, p. 463-488, 1945.

GROSH, D.S. \& HOOPYWOOD, L.E. Biological effects of radiation. $2^{\text {nd }}$ ed., Academic Press: New York, 1979.

GUARNIERI, M.C. Estudos dos efeitos da radiação gama de ${ }^{60} \mathrm{Co}$ nas propriedades bioquímicas, biológicas e imunológicas do veneno de Bothrops jararaca. Tese (Doutorado) - Instituto de Pesquisas Energéticas e Nucleares, São Paulo, 1992.

GUIDOLIN R.; DIAS DA SILVA W.; HIGASHI H.G.; CARICATI C.P.; LIMA M.L.S.R.; MORAIS J.F.; PINTO J.R.; MARCELINO J.R. Hiperimunização de cavalos soroprodutores com venenos botrópico e crotálico tratados por glutaraldeído. Mem. Inst. Butantan, v. 51, p. 85-90, 1989.

HAMPE, O.G.; VOZARI-HAMPE, M.M.; GONÇALVES, J.M. Crotamine conformation: effect of $\mathrm{pH}$ and temperature. Toxicon, v. 16, p. 453-460, 1978.

HANLEY, M. Crotoxin effects on Torpedo californica cholinergic excitable vesicles and the role of its phospholipase A activity. Biochem. Biophys. Res. Commun., v. 82, p. 392$401,1978$.

HANLEY, M.R. Conformation of the Neurotoxin Crotoxin Complex and Its Subunits. Biochemistry, v. 18(9), p. 1681-1688, 1979.

HARVEY, A.L.; ANDERSON, A.J.; MARSHAL, D.L.; PEMBERTON, K.E.; ROWAN, E.G. Facilitatory neurotoxins and transmitter release. J. Toxicol. - Toxins Reviews, v. 9, p. 225-242, 1990.

HATI, A.K.; HATI, R.N.; MANDAL, M.; PANDA, D.; DAS, S. The effect of gamma irradiated detoxified viper venom as a toxoid against viper venom. The Snake, v. 21, p. 36-40, 1989.

HAWGOOD, B.J.; SMITH, J.W. The mode of action at the mouse neuromuscular junction of the phospholipase A-crotapotin complex isolated from venom of the South American rattlesnake. Br. J. Pharmacol., v. 61, p. 597-606, 1977.

HAWKINS C.L.; DAVIES M.J. Generation and Propagation of Radical Reactions on Proteins. Biochim. Biophys. Acta, v. 1504(2-3), p. 196-219, 2001.

HENDON, R.A. \& FRAENKEL-CONRAT, H. Biological roles of the two components of crotoxin. Proc. Natl. Acad. Sci. USA, v. 68, p. 1560-1563, 1971. 
HENEINE, I.F.; HENEINE, L.G.D.; DANIEL, J.P.; NASCIMENTO, M.C.S.; ROCHA, O.A. Properties of protein toxins and venoms modified by controlled iodination. Academia de Ciências do Estado de São Paulo, v. 57-II, p. 55-66, 1988.

HENENE, I.F.; LAHMANN, W.M.; ROCHA, O.A. A toxoid prepared for cholera toxin by iodination. Braz. J. Med. Biol. Res., v. 25, p. 913-917, 1992.

HERNANDEZ-OLIVEIRA, S.; TOYAMA, M.H.; TOYAMA, D.O.; MARANGONI, S.; HYSLOP, S.; RODRIGUES-SIMIONI, L. Biochemical, Pharmacological and Structural Characterization of a New PLA2 from Crotalus durissus terrificus (South American Rattlesnake) Venom. Protein J., v. 24(4), p. 233-242, 2005.

HIGASHI, H.G.; GUIDOLIN, R.; NISHIKAWA, A.K.; YAMAGUCHI, I.K.; LIMA, M.L.S.R.; MORAIS, J.F.; DA SILVA, W. D. Venenos botrópicos pré-tratados com inibidores ativos para os sítios enzimáticos de protease e com substância quelante preservam seu poder imunogênico. Mem. Inst. Butantan, v. 51, p. 107-115, 1989.

HOGE, A.R. \& ROMANO-HOGE, S.A.R.W.L. Sinopse das serpentes peçonhentas do Brasil, $2^{a}$ ed. Mem. Inst. Butantan, v. 42/43, p. 373-496, 1978/79.

HORTNAGEL, H. \& HANIN, J. Toxins affecting the cholinergic system. 1992. In. Selective neurotoxicity. Herken, H.; Hucho, F. (Eds.). Springer, Berlin Heldelberg New York, p. 293-332.

JORGE, M.T. \& RIBEIRO, L.A. Acidentes por serpentes peçonhentas do Brasil. Rev. Ass. Med. Bras. São Paulo, v. 36(2), p. 66-77, 1990.

KANKONKAR, S.R.; KANKONKAR, R.C.; GAITONDE, B.B.; GROSH, S.V. Irradiated cobra (Naja Naja) venom for biomedical applications. In: Radiosterilization of Medical Products. IAEA, 1975.

KARDONG, K.V. Colubrid snakes and Duvernoy's "venom" glands. Toxin Reviews, v. 21, p. 1-19, 2002.

KASTURIRATNE, A.; WICKREMASINGHE, A.R.; DE SILVA, N., GUNAWARDENA, N.K.; PATHMESWARAN, A., PREMARATNA, R.; SAVIOLI, L.; LALLOO, D.G.; DE SILVA, H.J. Estimating the global burden of snakebite: A literature analysis. PLoS Med., v, 5(11), p. 1591-1604, 2008.

KAWANO, Y.; LAURE, C.J.; GIGLIO, J.R. Laser Raman study on crotamine. Biochem. Biophys. Acta, v. 705, p. 20-25, 1982.

KINI, R.M. Venom Phospholipase A2 Enzymes: Structure, Function and Mechanism. 1997. Kini, R.M. (Ed.). Wiley, Chichester, England, p. 1-511.

KONG, J.; YU, S. Fourier Transform Infrared Spectroscopic Analysis of Protein Secondary Structures. Acta Biochim. Biophys. Sin., v. 39(8), p. 549-559, 2007.

KRISHNAN, K.S. \& BRANDTS, J.F. Scanning calorimetry. Methods Enzymol., v. 49, p. 3-14, 1978.

LADBURY, J.E.; KISHORE, N.; HELLINGA, H.W.; WYNN, R.; STURTEVANT, J.M. Thermodynamics effects of reduction of the active-site disulfide of Escherichia coli 
thioredoxin explored by differential scanning calorimtery. Biochem.,v. 33, p. 3688-3692, 1994.

LAURE, C.J. Die Primar strutur des crotamins. Hope Seylers z. Physiol. Chem., v. 356, p. 213-215, 1975.

LI, Y.; FORAN, P.; FAIRWEATHER, N.F.; PAIVA, A.; WELLER, U.; DOUGAN, G.; DOLLY, J.O. A single mutation in the recombinant light chain of tetanus toxin abolishes its proteolytic activity and removes the toxicity seen after reconstitution with native heavy chain. Biochemistry, v. 33, p. 7014-7020, 1994.

MANDAL, M.; HATI, R.N.; BARDHAN, D.K; HATI, A.K. Effect of gamma radiation on Cobre (Naja Naja) venom as a toxoid. The Snake, v. 23, p. 44-48, 1991.

MANDAL, M.; HATI, R.N.; HATI, A.K. Neutralization of pathophysiological manifestations of Russel's viper envenoming by antivenom raised against gamma-irradiated toxoid. Toxicon, v. 31, p. 213-216, 1993.

MARCHI-SALVADOR, D.P.; CORREA, L.C.; MAGRO, A.J.; OLIVEIRA, C.Z.; SOARES, A.M.; FONTES, M.R. Insights into the role of oligomeric state on the biological activities of crotoxin: crystal structure of a tetrameric phospholipase A2 formed by two isoforms of crotoxin B from Crotalus durissus terrificus venom. Proteins, v. 72, p. 883-891, 2008.

MÈNEZ, A. Les venims et toxins des serpents. 1994. In: Goyffon, M. \& Heurtaut, J. (Eds.). La function venimeuse, Masson, p. 200-220.

MICHAELS, H.B.; HUNT, J.W. A model for radiation damage in cells by direct effect and by indirect effect: a radiation chemistry approach. Radiat. Res., v. 74, p. 23-34, 1978.

MINISTÉRIO DA SAÚDE. Estatística anual de casos de envenenamentos ofídicos. Disponível em: <http://portal.saude.gov.br/portal/saude/profissional/visualizar_texto.cfm? idtxt=31500 >. Acesso em 07 set. 2009.

MOROZ, C.; GOLDBLUM, N.; DE VRIES, A. Preparation of Vipera palestinae antineurotoxin using carboxymethylcellulose bound neurotoxin as antigen. Nature, v. 200, p. 228-233, 1963.

MURAKAMI, M.T. \& ARNI, R.K. A structure based model for liposome disruption and the role of catalytic activity in myotoxic phospholipase $A_{2}$ S. Toxicon, v. 42, p. 903-913, 2003.

MURATA, Y. Efeitos da radiação gama no veneno de Crotalus durissus terrificus. 1988. Dissertação (Mestrado) - Instituto de Pesquisas Energéticas e Nucleares, São Paulo.

NASCIMENTO, N. Caracterização bioquímica e imunológica dos principais produtos gerados pela irradiação de crotoxina. 1995. Tese (Doutorado) - Instituto de Pesquisas Energéticas e Nucleares, São Paulo.

NASCIMENTO, N. Estudo comparativo entre crotoxina nativa e irradiada. Aspectos bioquímicos e farmacológicos. 1991. Dissertação (Mestrado) - Instituto de Pesquisas Energéticas e Nucleares, São Paulo.

NASCIMENTO, N.; SEEBART, C.S.; FRANCIS, B.; ROGERO, J.R.; KAISER, I.I. Influence of ionizing radiation on crotoxin: biochemical and immunological aspects. Toxicon, v. 34(1), p. 123-131, 1996. 
NAUMANN, D. FT-Infrared and FT-Raman Spectroscopy in biomedical research. Appl. Spectr. Reviews., v. 36(2\&3), p. 239-298, 2001.

NAUMANN, D. Infrared spectroscopy in microbiology. 2000. In: Meyers, R.A. (Ed.), Encyclopedia of Analytical Chemistry. John Wiley \& Sons, Chichester, UK, p. 102-131.

NICASTRO, G.; FRANZONI, L.; DE CHIARA, C.; MANCIN, A.C.; GIGLIO, J.R.; SPISNI, A. Solution structure of crotamine, a $\mathrm{Na}+$ channel affecting toxin of Crotalus durissus terrificus venom. Eur. J. Biochem., v. 270(9), p. 1969-1979, 2003.

OGUIURA, N. Caracterização do gene da crotamina nas variedades crotamina positiva e crotamina - negativa da cascavel Crotalus durissus terrificus. 1998. Tese (Doutorado) - Instituto de Biociências da Universidade de São Paulo, São Paulo.

OKONOGI, T.; HATTORI, Z.; OGIJO, A.; MITSUI, S. Detoxification by persimmon tannin of snake venoms and bacterial toxins. Toxicon, v. 17, p. 524-527, 1979.

OWNBY, C.L. Structure, function and biophysical aspects of the myotoxins from snake venoms. J. Toxicol. - Toxin Reviews, v. 17(2), p. 213-238, 1998.

PAINE, M.J.I.; DESMOND, H.P.; THEAKSTON, R.D.G.; CRAMPTON, J.M. Gene expression in Echis carinatus (carpet viper) venom glands following milking. Toxicon, $v$. 30, p. 379-386, 1992.

PELTRON, J.T. \& MCLEAN, L.R. Spectroscopic Methods for Analysis of Protein Secondary Structure. Anal. Biochem., v. 227, p. 167-176, 2000.

PHISALIX, L.D.; BERTRAND, G. Sur la propriété antitoxique du sang des animaux vaccinés contre le venin di vipère. C. R. Acad. Sci., v.118, p. 356-358, 1894.

PINHO, J.R.R.; CARDI, B.A.; ANDRADE Jr., H.F.; BARR, P.J.; BATHURST, I.C.; VICENTE, E.J.; SCHENBERG, A.C. Immunogenic properties of the $M$. leprae recombinant 18-Kda antigen purified from Saccharomyces cerevisae; Enhancement of delayed-type hypersensitivity after gamma-irradiation. Int. J. Leprosy, v. 63(3), p. 381390, 1995.

PLUM, G.E. \& BRESLAUER, K.J. Calorimetry of proteins and nucleic acids. Curr. Opin. Struct. Biol., v. 5, p. 682-690, 1995.

POUGH, F.H.; ANDREWS, R.M.; CADLE, J.E.; CRUMP, M.L.; SAVITZKY, A.H.; WELLS, K.D. Herpetology, Prentice-Hall, 1998, 577p.

PRIVALOV, P. L. \& KHECHINASHVILI, N.N. A thermodynamic approach to the problem of stabilization of globular protein structure: A calorimetric study. J. Molec. Biol., v. 86, p. 665-684, 1974.

PRIVALOV, P.L. Scanning microcalorimeters for studying macromolecules. Pure Appl. Chem., v. 52, p. 479-497, 1980.

PROTEIN DATA BANK. Banco de dados. Disponível em:< http://www.rcsb.org/pdb/home/home.do >. Acesso em: 10 jan. 2010. 
PURANANANDA, C. Studies on effects of radiations on snake venoms with special aspects on the sterelization. Int. Atomic Energy Agency, Viena, 1972.

RELYVELD, E.H.; GIRARD, O.; CHEYROUX, M.; ASSO, J.; DE RUDDER, J. Nouveau procédé d'inactivation pour la preparation de vaccins. Dev. Biol. Stand., v. 27, p. 236348, 1974.

RIBEIRO, L.A. \& JORGE, M.T. Acidentes por serpentes do gênero Bothrops série de 3139 casos. Rev. Soc. Bras. Med. Trop., v. 30, p. 475-480, 1997.

RIZZI, C.T.; CARVALHO-DE-SOUZA, J.L.; SCHIAVON, E.; CASSOLA, A.C.; WANKE, E.; TRONCONE, L.R. Crotamine inhibits preferentially fast-twitching muscles but is inactive on sodium channels. Toxicon, v. 50(4), p. 553-562, 2007.

RODGER, A. \& NORDÉN, B. Circular Dichroism and Linear Dichroism. 1997. Oxford University Press, Oxford.

ROSENFELD, G. Ação neurotóxica de venenos ofídicos (Crotalus e Micrurus) no sistema nervoso central. Interpretação clínica. Ciênc. e Cul., v. 23, p. 1-45, 1971. Suplemento.

ROSENFELD, G. Acidentes por Animais Peçonhentos. 1991. In: Doenças Infecciosas e Parasitárias. Veronesi, R. (Ed.), 8ª ed. Rio de Janeiro, Guanabara Koogan, p. 951-962.

ROTENBERG, D.; BAMBERGER, E.S.; KOCHVA, E. Studies on ribonucleic acid synthesis in the venom glands of Vipera palaestinae (Ophidia, Reptilia). Biochem. J. v. 121, p. 609-612, 1971.

RUBSAMEN, K.; BREITHALPT, H.; HABERMANN, E. Biochemistry and Pharmacology of the crotoxin complex. N-S Arch. Pharmacol., v. 270, p. 274-288, 1971.

SANCHEZ-RUIZ, J.M. Differential Scanning Calorimetry of Proteins. In: Subcellular Biochemistry. Proteins: Structure, function, and Engineering. Ed. B.B. Biswas and Siddhartha Roy. Plenum Press, New York, v. 24, 1995.

SANTOS, K.F.; MURAKAMI, M.T.; CINTRA, A.C.O.; TOYAMA, M.H.; MARANGONI, S.; FORRER, V.P.; BRANDÃO NETO, J.R.; POLIKARPOV, I.; ARNI, R.K. Crystallization and preliminary X-ray crystallographic analysis of the heterodimeric crotoxin complex and the isolated subunits crotapotin and phospholipase A2. Acta Crystallogr. Sect. F Struct. Biol. Cryst. Commun., v. 66, p. 287-290, 2007.

SCHENBERG, S. Geographical pattern of crotamine distribution in the same rattlesnake subspecies. Science, v. 129, p. 1361-1363, 1959.

SHORT, H.E.; MALLLICK, S.M.K. Detoxication of snake venoms by the photodynamic action of methylene blue. Indian J. Med. Res., v. 22, p. 529-536, 1935.

SILVA, C.A.; PORTARO, F.C.V.; FERNANDES, B.L.; IANZER, D.A.; GUERREIRO, J.R.; GOMES, C.L.; KONNO, K.; SERRANO, S.M.T.; NASCIMENTO, N.; CAMARGO, A.C.M. Tissue distribution in mice if BPP 10c, a potent proline-rich anti-hypertensive peptide of Bothrops jararaca. Toxicon, v. 51, p. 515-523, 2007.

SILVA, S.H.O. Estudo comparativo - Bioquímico e Imunofarmacológico - do Veneno Total, da Crotoxina e Suas Isoformas de Crotapotina e PLA2, de Crotalus 
durissus terrificus, C.d.ruruima, C.d.cascavella e C.d.collilineatus. Tese (Doutorado) - Unicamp, Campinas/SP, 2005.

SIQUEIRA, A.M.; MARTINS, N.F.; DE LIMA, M.E.; DINIZ, C.R.; CARTIER, A.; BROWN, D.; MAIGRET, B. A proposed 3D structure for crotamine based on homology building, molecular simulations and circular dichroism. J. Mol. Graph. Model., v. 20(5), p. 389-398, 2002.

SKALKA, M. \& ANTONI, F. Effect of radiation on the biological properties of proteins. 1970. In: Radiation sensitivity of toxins and animal poisons., Ed. Int. Atomic Energy Agency, p. 1-13.

SLOTTA C.H. \& FRAENKEL-CONRAT, M. Purificação e cristalização do veneno da cobra cascavel. Mem. Inst. Butantan, v. 12, p. 505-513, 1938.

SPENCER, P.J. Alterações bioquímicas e imunológicas do veneno de Bothrops jararacussu irradiado com ${ }^{60}$ Co. 1995. Dissertação (Mestrado) - Instituto de Pesquisas Energética e Nucleares, São Paulo.

SPENCER, P.J. Efeitos da radiação na estrutura da Bothropstoxina-I. 1999. Tese (Doutorado) - Instituto de Pesquisas Energéticas e Nucleares, São Paulo.

STOCKER, K.F. Composition of snake venoms. 1990. In: Stocker, K.F. (Ed.), Medical Use of Snake Venom Proteins, CRC Press, Boca Raton, FL, p. 33-56.

STRICKLAND, E.H. Aromatic contributions to circular dichroism spectra of proteins. CRC Crit. Rev. Biochem., v. 2(1), p. 112-175, 1974.

STURTEVANT, J.M. The thermodynamic effects of protein mutations. Curr. Opin. Struct. Biol., v. 4, p. 69-78, 1994.

TEJASEN, P.; OTTOLENGHI, A. The effect of ultraviolet light on the toxicity and the enzymatic and antigenic activities of snake venom. Toxicon, v. 8, p. 225-233, 1970.

THOMAS, R.G.; \& POUGH, F.H. The effect of rattlesnake venom on digestion of prey. Toxicon, v. 17, p. 221-228, 1979.

THOMSON, J.; RATNAPARKHI, G.S.; VARADARAJAN, R.; STURTEVANT J.M.; RICHARDS, F.M. Thermodynamic and structural consequences of changing a sulfur atom to a methylene group in the M13Nle mutation in ribonuclease-S. Biochem., v. 33, p. 8587-8593, 1994.

TOCKER, J.E.; DURHAM, S.K.; WELTON, A.F. Phospholipase A2-induced pulmonary and hemodynamic responses in the guinea pig. Am. Rev. Resp. Dis., v. 142, p. 11931199, 1990.

TOYAMA, M. H.; CARNEIRO, E. M.; MARANGONI, S.; BARBOSA, R. L.; CORSO, G.; BOSCHERO, A. C. Biochemical characterization of two crotamine isoforms isolated by a single step RP-HPLC from Crotalus durissus terrificus (South American rattlesnake) venom and their action on insulin secretion by pancreatic islets. Biochem. et Biophis. Acta, v. 1474, p. 56-60, 2000. 
VARGAFTIG, B.B.; JOSEPH, D.; WAL, F.; MARLAS, G.; CHIGNARD, M.; CHEVANCE, G.L. Convulxin-induced activation of intact and of thrombin-degranulated rabbit platelets: specific crossed desensitisation with collagen. Eur. J. Pharmacol., v. 92, p. 57-68, 1983.

VITAL BRAZIL, O. \& EXCELL, B.J. Action of crotoxin and crotactin from the venom of Crotalus Durissus terrificus (South American rattlesnake) on the frog neuromuscular junction. J. Physiol., v. 212, p. 34-35, 1971.

VITAL BRAZIL, O. Contribuição ao estudo do veneno ophídico. I - Espécies venenosas brasileiras; mortalidade por mordedura de cobras. Rev. Med. Trop. São Paulo, v. 4, p. 255-260, 1901.

VITAL BRAZIL, O. Venenos ofídicos neurotóxicos. Rev. Ass. Med. Bras., v. 26, p. 212218, 1980.

VITAL BRAZIL, O.; EUGÊNIO, A.G.B.; LASZLO, G.M. Origem da paralisia respiratória causada pela crotoxina. Ciênc. e Cult., v. 25, p. 1165-1169, 1973.

VITAL BRAZIL, O.; FRANCESCHI, J.P.; WAISBICH, E.P.Pharmacology of cristalline crotoxin. I. Toxicity. Mem. Inst. Butantan, v. 32, p. 973, 1966a.

VITAL BRAZIL, O.; FRANCESCHI, J.P.; WAISBICH, E.P.Pharmacology of cristalline crotoxin. II. Neuromuscular blocking action. Mem. Inst. Butantan, v. 33, p. 991-992, 1966b.

VITAL BRAZIL, O.; PRADO-FRANCHESI, J.P.; LAURE, C.J. Repetitive muscle responses induced by crotamine. Toxicon, v. 17, p. 61-67, 1979.

WALES, A. \& KUSEL, J.R. Biochemistry of irradiated Parasite vaccines: suggested models for their mode of action. Parasitol. Today, v. 8(11), p. 358-363, 1992. 